Eating behaviors among Norwegian schoolchildren in relation to gender and socioeconomic status

\author{
Department of Nutrition \\ University of Oslo / \\ Department of Public Health, Sport and Nutrition \\ University of Agder
}

Marit Hilsen

2011 
(C) Marit Hilsen, 2012

Series of dissertations submitted to the Faculty of Medicine, University of Oslo No. 1322

ISBN 978-82-8264-300-9

All rights reserved. No part of this publication may be reproduced or transmitted, in any form or by any means, without permission.

Cover: Inger Sandved Anfinsen.

Printed in Norway: AIT Oslo AS.

Produced in co-operation with Unipub.

The thesis is produced by Unipub merely in connection with the thesis defence. Kindly direct all inquiries regarding the thesis to the copyright holder or the unit which grants the doctorate. 


\section{TABLE OF CONTENTS}

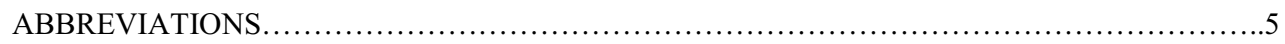

ACKNOWLEDGEMENTS..................................................................

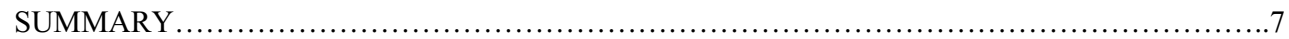

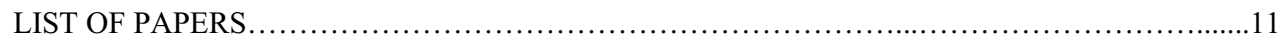

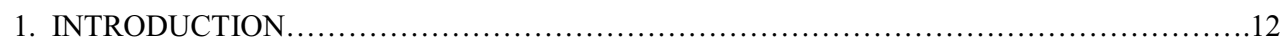

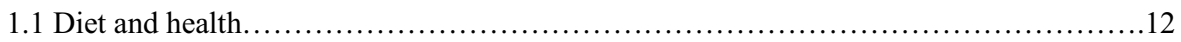

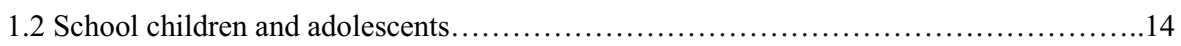

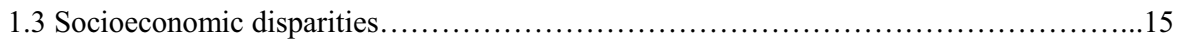

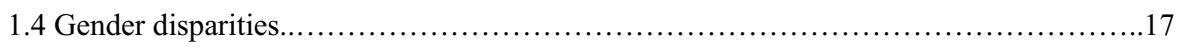

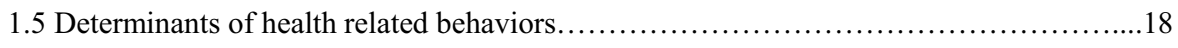

1.6 The Norwegian School Fruit Programme......................................................................19

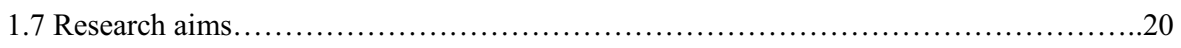

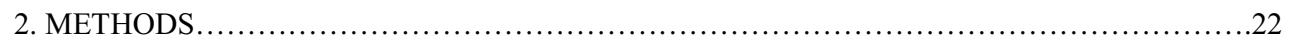

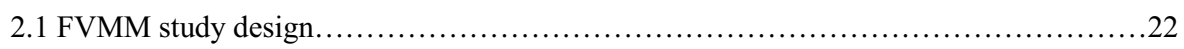

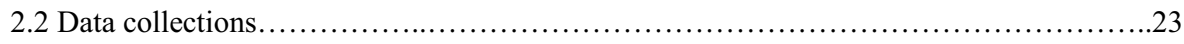

2.2.1 Data collection procedures.............................................23

2.2.2 Existing data......................................................

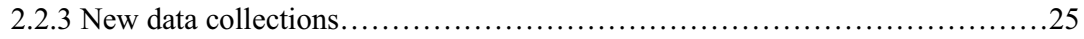

2.2.3.1 Fourth follow-up survey of cohort I............................25

2.2.3.2 Baseline survey of cohort II................................25

2.3 Study samples used in this Ph.D. thesis.......................................... 25 
2.4 Research instruments

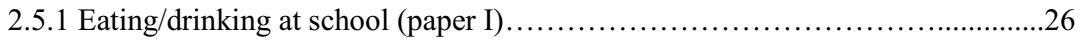

2.5.2 Fruit and vegetable intake (papers II and III) ................................................27

2.5.3 Determinants of fruit and vegetable intake.....................................28

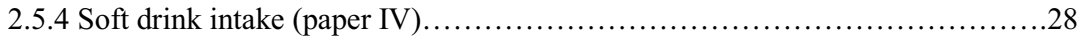

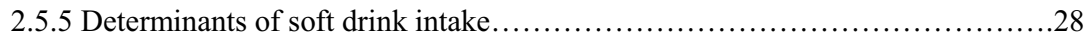

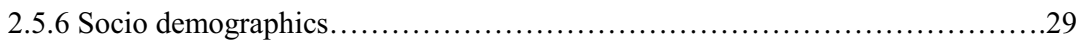

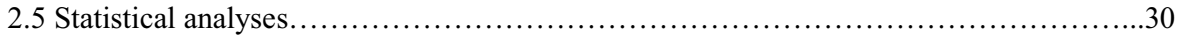

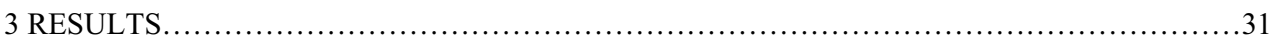

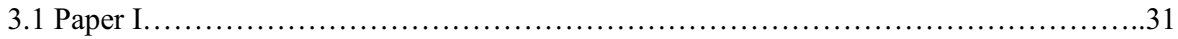

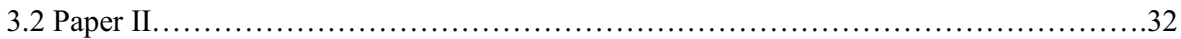

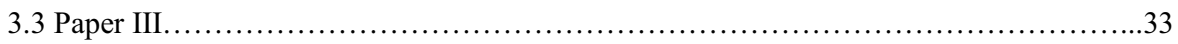

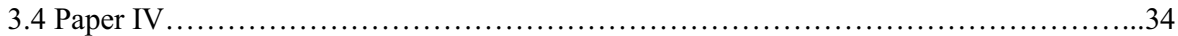

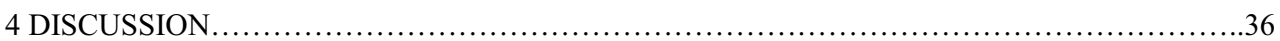

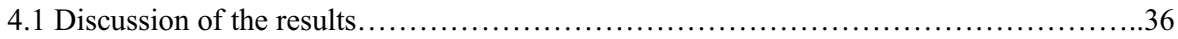

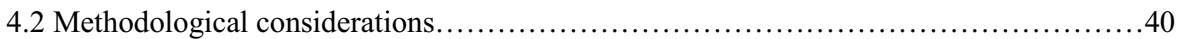

4.2 .1 Design of the study ...............................................40

4.2.2 Questionnaire/instrument...........................................41

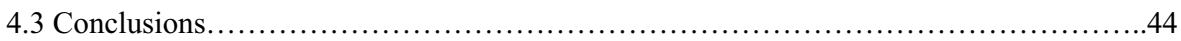

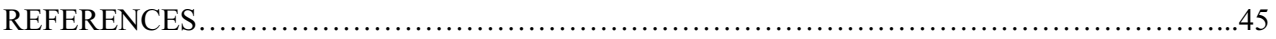

PAPERS I-IV

APPENDICES 


\section{ABBREVIATIONS}

BMI

Body mass index

CI Confidence interval

FFQ Food frequency questionnaire

FV Fruits and vegetables

FVMM Fruits and Vegetables Makes the Marks

NOK Norwegian Kroner

SCT Social cognitive theory

SDC Sugar-sweetened soft drink consumption

SE Standard error

SES Socioeconomic status

SPSS Statistical package for the social sciences

TPB Theory of planned behavior

WHO World Health Organization 


\section{ACKNOWLEDGEMENTS}

The work of this thesis was conducted from August 2008 to August 2011 at the University of Agder (Department of Public Health, Sport and Nutrition), University of Oslo (Department of Nutrition) and VU Medical Centre, Amsterdam (EMGO Institute for Health and Care Research). The Norwegian Research Council has financed the work and data collections.

First, I would like to thank my principal supervisor Elling Bere for giving me the opportunity to do this thesis and for inspiring and encouraging support during this work. I would also like to thank Giske Ursin for being my co-supervisor. I am also very grateful to Johannes Brug and Saskia J te Velde for their warm welcome and excellent guidance during my stay in Amsterdam - thank you! To the coauthors of the papers included in this thesis, Terje A Eikemo, Maartje M van Stralen and Knut-Inge Klepp - thank you for your sharing your knowledge and contributing to the publication of these articles. I would like to thank my colleagues Line Anita Bjørkelund Børrestad, Frøydis Nordgård Vik and Rita Eng for their invaluable contributions regarding the data collections. I am also deeply grateful to all the principals, teachers, pupils and parents who participated in the surveys. To all my colleagues, classmates and friends - thank you for all your support and inspiration during these years. To my boyfriend Rob - thank you for helping me in recharging my batteries and balance my perspectives after long days of work.

And, to my parents, Anne-Mai and Trond, I would like to dedicate a very special and warm thank you for their endless love, encouragement and support in everything I do, including this thesis.

Marit Hilsen

Amsterdam, 2011 


\section{SUMMARY}

Eating behaviors are closely related to the risk of developing several chronic diseases such as cardiovascular diseases (CVD), several cancers and diabetes type II. Improving eating behaviors are therefore important to reduce the incidence of these diseases. According to the national guidelines on dietary intake in Norway the consumption of fruits and vegetables (FV) is low whereas the sugar-sweetened soft drinks consumption (SDC) and other unhealthy food items are high both among adults and children. As eating behaviors are established during childhood/adolescents and track well into adulthood, these are important periods to initiate and sustain healthy eating behaviors in order to obtain a maximum preventive effect on diet related diseases later in life. Both among adults and children there are large gender and social disparities in eating behaviors - i.e. boys and lower socioeconomic groups having less healthy eating behaviors. Exploring why we observe these differences is of great importance in order to make efficient interventions in the future to improve the eating behaviors of these groups. The overall aim of this thesis was to study gender and socioeconomic disparities in eating behaviors and in determinants of eating behaviors among Norwegian pupils.

This thesis includes data from two cross sectional surveys among Norwegian $6^{\text {th }}$ and $7^{\text {th }}$ graders participating in the Fruit and Vegetable Makes the Mark project (FVMM). The sample sizes include 27 schools participating in 2001 (1488 pupils) and 27 schools participating in 2008 (1339 pupils). The thesis also includes data from a third follow-up survey of the 2001-pupils in 2005. The pupils were then in $9^{\text {th }}$ and $10^{\text {th }}$ grades and this study sample include 33 schools (2870 pupils). In all surveys data was collected by questionnaires including a 24-hour recall of FV intake, a food frequency questionnaire (FFQ) of FV intake, SDC and other healthy and unhealthy food items, as well as questions on potential determinants of the intake such as perceived accessibility at home, preferences, attitudes and modeling. In the 2001 and 2008 surveys similar data was also collected from the parents by a 
parent questionnaire. Between 2001 and 2008 official school fruit programs were initiated in Norway, and in 2008 the schools therefore differ according to the pupil's accessibility of FV at school. At some schools the pupils received a fruit or vegetable every school day (either through a free school fruit program or a subscription program) whereas other schools had no such program. The results from the 2001 and 2008 surveys are presented in paper II and III. The results from the third follow-up survey in 2005 are presented in paper I and IV.

Assessed by the 24-hour recall the results showed that the FV intake among the $6^{\text {th }}$ and $7^{\text {th }}$ graders had increased from 2001 to 2008 (paper II). The highest increase was observed among the pupils at schools which participated in a free fruit program and the effect of this program was the same regardless of gender and SES. Among the pupils at schools not participating in any fruit program there had been a less profound change in the pupils FV intake during the same period. The effect observed was mainly due to an increase in the pupils' fruit intake whereas their vegetable intake still remained low.

When assessed by the FFQ's the results showed that the FV intake had slightly decreased from 2001 to 2008 (paper III). For the same period we found that the mean scores of perceived accessibility at home and preferences of FV had increased, and mediation analyses indicated that the decrease in FV consumption was suppressed by the increase in accessibility and preferences. Subgroup analysis showed that the FV intake had decreased among pupils with parents of lower educational level and slightly increased among pupils of parents with higher educational level - i.e. the social disparities in FV intake over time had increased. This increased disparity over time was partly mediated by an increased disparity in accessibility and preferences.

Results from the third follow-up study showed that few pupils reported to eat FV at school while a large proportion of the pupils reported to consume snacks, sweet bakery and soft 
drinks at school (paper I). The girls and pupils planning to attend higher education after secondary school consumed FV more often, and unhealthy foods less often, than boys and pupils without plans of higher education. Large between-school differences in eating behaviors at school were also observed.

Gender and SES disparities in SDC were observed in our study sample. The gender differences in SDC among the pupils in the third follow-up study were strongly associated with gender differences in attitudes and preferences whereas the pupils' educational plans differences in SDC were strongly associated with educational differences in accessibility and modeling (paper IV). Both the gender and educational differences in SDC were partly mediated by accessibility, modeling, attitudes and preferences. Further, the results showed that both gender and educational plans moderated the associations between attitudes, preferences, accessibility, modeling and SDC.

The results from this thesis confirm previously reported gender and SES differences in eating behaviors among children and adolescents. These differences in eating behaviors were also found among the pupils at school and were observed both regarding FV intake, SDC and their potential determinants. Further, it also shows that the social disparities in FV intake has increased over time, partly explained by increased disparities in perceived accessibility at home and preferences of FV among the pupils. However, the national school fruit program showed no significant difference in the effect of the program in relation to gender or SES, and free school fruit appear to be effective in increasing all groups of pupils' fruit intake. 
More research on gender and social difference in eating behaviors among children and adolescents is needed, especially longitudinal studies and interventions studies focusing on how to improve eating behaviors among boys and lower SES groups. 


\section{LIST OF PAPERS}

Paper I

Hilsen M, Eikemo TA, Bere E. Healthy and unhealthy eating at lower secondary school in Norway. Scandinavian Journal of Public Health 2010 Nov;38(5 suppl):7-12.

\section{Paper II}

Bere E, Hilsen M, Klepp KI. Effect of the nationwide free school fruit scheme in Norway. British Journal of Nutrition 2010 Aug;104(4):589-94.

\section{Paper III}

Hilsen M, van Stralen MM, Klepp KI, Bere E. Changes in 10-12 year old's fruit and vegetable intake in Norway from 2001 to 2008 in relation to gender and socioeconomic status - a comparison of two cross-sectional groups. International Journal of Behavioral Nutrition and Physical Activity 2011, 8:108.

\section{Paper IV}

Hilsen M, te Velde SJ, Bere E, Brug J. Predictors and mediators of differences in soft drink consumption according to gender and plans of further education among Norwegian secondary schoolchildren. Public Health Nutrition 2011, accepted for publication October $11^{\text {th }}$. 


\section{INTRODUCTION}

\subsection{Diet and health}

Eating behaviors have been studied in relation to several diseases and the results have shown that a favorable diet may decrease the risk of developing chronic diseases such as obesity, diabetes, cardiovascular diseases (CVD), several cancers, dental diseases and osteoporosis $(1 ; 2)$. A decreased risk of developing these diseases is desirable both at an individual and nationwide level by increasing life quality across the lifespan and reducing the burdens of, and costs associated with treating these diseases. National dietary recommendations have been developed to guide the public in how to obtain a health promoting diet in order to promote health and reduce the risk of these diseases (2).

One of the food groups which is found health promoting and may reduce the risk of some of the diseases mentioned above is fruits and vegetables (FV). FV are low in energy and rich in fiber, vitamins, minerals and antioxidants. The World Health Organization (WHO) recommends an intake of at least 400 grams of FV per day, also defined as 5 portions/servings of a varity of FV of 80 grams per portion/serving (1). The dietary recommendations from the Norwegian health authorities is to eat at least 500 grams of FV per day ( 5 portions/servings per day), preferably half the amount as vegetables and half the amount as fruits and berries (2). The size of one portion/serving is approximately 100 grams. It is recommended to consume a wide variation of FV. Berries and fruit juices are also included in the recommendations but the daily intake of fruit juices can only count as maximum one portion/serving (glass of 1,5 dl) per day. Potatoes are not included when summarizing the total daily amount/servings of FV. The recommendations are aimed at the adult population. Children are recommended the same number of servings per day but served as smaller amounts (grams) per portions. However, the sizes of the smaller amounts per serving for 
children are not specified. In most European countries the intake of FV is lower that the recommended intake for both adults and children $(3 ; 4)$ and a study among Norwegian children and adolescents shows that they eat less than half of the recommended 5 portions of FV per day (5).

One of the least health promoting food products at the marked are the carbonated sugarsweetened soft drinks. These sugar-sweetened soft drinks are high in added sugar and, in addition to being a nutrient-poor source of energy, soft drinks contain inherent acids (low $\mathrm{pH}$ ) which may lead to dental erosion. Soft drinks are highly available and consumption is distressed because it may add excessive energy to the diet and/or replace other foods high in essential nutrients. Both the WHO and the Norwegian dietary guidelines recommends a maximum of $10 \%$ of daily energy intake from free sugars $(1 ; 2)$. According to WHO the term 'free sugars' refers to all monosaccharides and disaccharides added to foods by the manufacturer, cook or consumer, plus sugars naturally present in honey, fruit juices and syrups (1). A study among $8^{\text {th }}$ graders in Norway showed that $18 \%$ of energy intake came from free sugars; for $89 \%$ of the children more than $10 \%$ of energy intake was from free sugars, and soft drinks contributed $30 \%$ to total added sugar intakes (6). Other studies also report a high and increasing consumption of sugar-sweetened soft drinks among children and adolescents (7-10) as well as an increase in the availability of soft drinks (11) in recent years. However, recent results from the FVMM study shows that sugar-sweetened soft drink consumption (SDC) has decreased among Norwegian $6^{\text {th }}$ and $7^{\text {th }}$ graders from 2001 to 2008 (12).

Part of the aim in Norway to improve the puplic health is to increase the intake of FV and to reduce SDC (13). 


\subsection{Schoolchildren and adolescents}

During early childhood the eating environment and taste experiences of children are strongly influenced by their parents (14). However, as the children grow older they are also exposed to other eating environments and role models. School becomes an important arena where the children consume at least one meal per day, usually lunch, and their role models are expanded by teachers and pupils. In the transition from childhood to adolescence even more diverse food environments and more potential role models are unfolded. Adolescence is a period characterized by more autonomy. The growing independence and frequency of meals consumed away from home may result in changing eating behaviors. As adolescents is considered one of the most crucial periods in life in regards to nutrient needs for optimal health development (15) it is important that the potential changes in eating behaviors during this period are health promoting.

Studies have shown that as the children get older the intake of healthy foods such as FV decreases and the consumption of unhealthy food such as sweets, snacks and soft drinks increases (16). It has also been reported that eating behaviors established during childhood and adolescents track into adulthood $(16 ; 17)$. Since the diet is one of the major factors that may reduce the risk of several chronic diseases it is important to establish health promoting eating behaviors as early in life as possible and to work on maintaining these into adult life. Establishing healthy eating behaviors in childhood and maintain and develop them further as the children are getting older gives a potential for maximum preventive effect on chronic diseases across the lifespan.

Studying and targeting children and adolescents in health related research and interventions are also favorable because they are all in school during this period in life. The schools may serve as a good arena to reach all children and adolescents with potential health promoting initiatives. 


\subsection{Socioeconomic disparities}

Socioeconomic status (SES) is an individual's or a group's position in social standing relative to others which is most commonly assessed by level of education, income and/or occupation. Large differences in health behaviors and health outcomes have been observed between the groups. Multiple risk behaviors such as smoking, excessive alcohol intake, sedentary lifestyle and poor diets are more frequently observed among low SES groups (18) and several studies have shown that SES is associated with chronic diseases such as CVD (19), some cancers (20), diabetes type II (21) and obesity (22) - i.e. low SES groups are at higher risk of developing these diseases compared to higher SES groups.

The most profound characteristics of the less healthy dietary behaviors reported among low SES groups includes a lower intake of FV and a higher intake of foods with a high content of sugar and/or fat compared to the diet of high SES groups (23). Seen in relation to the energy content FV are among the most expensive foods (24). This may be a contributing factor to why we observe a lower intake of FV among low SES groups as the lower SES groups tend to have a lower income compared to high SES groups. In order to achieve the same total energy intake per day through a diet rich in FV it will be more expensive compared to a diet rich in more energy dense foods. Studies have also shown that the more healthy diets reported in high SES groups may also be due to greater knowledge, health concerns and support by family/friends (25).

SES is also a widely used assessment when studying health behaviors among children and adolescents. The children and adolescents' SES is usually based on the parents SES as described above. Similar results as for the adults such as poor diets, less physical activity and 
greater cigarette smoking have also been found among children and adolescents (26). The poorer diets of children and adolescents of lower SES also includes a lower intake of FV $(27 ; 28)$ and a higher intake of candy and soft drinks (28) compared to children and adolescents of higher SES groups.

As adolescence is a transition period towards more independence the validity of parental SES as an indicator of the adolescent social standing has been questioned. Due to structural changes in society regarding education during the last decades adolescents may, in a higher degree than before, choose a different education than their parents - i.e. fall into a different category of SES than their parents when education is used as an indicator of SES (29). A previous study among Norwegian adolescents showed that all though there was a high correlation between adolescents of parents with college/university education who planned college/university education, there was also a high proportion of adolescents of parents without college/university education who planned college/university education (29). Another finding of this study which may illustrate the increasing independence as the adolescents grow older is that the correlation between the adolescents report of their own educational plans and perceived educational plans of their parents decreased from age 13 to 15 .

The gap in health behaviors between the SES groups is unfortunate and may reinforce an already unfavorable situation of those in the lower SES groups by resulting in more challenges during their lifespan related to health. However, as SES in itself is not assumed to have a direct effect on health behaviors and outcomes, the factors associated with poor health related behavior in low SES groups may be improved. A reduction of the unfortunate health outcomes observed in the low SES group would be beneficial for all, both individuals and society, by reducing the risk of several diseases and the associated costs and burdens. 


\subsection{Gender disparities}

WHO report that women, on average, live 6 to 8 years longer than men globally (30). This difference in life expectancy between the genders is also observed in Norway. Although the disparity in life expectancy among Norwegian men and women has decreased during the last years, data from 2010 shows that women live 4.3 years longer than men. The current expected average age is 83,2 for women and 78,9 for men (31). Results published by the Statistics Norway (SSB) also shows that men in all age groups have a higher mortality rate than women

The differences in eating behaviors according to gender show that men tend to make less healthy food choices according to the nutritional recommendations compared to women. Dietary surveys show that men eat more meat and have a higher alcohol consumption than women, while women eat more FV compared to men $(33 ; 34)$. The reasons for this are still unclear but it has been reported that the gender differences in FV intake are associated with less knowledge of the current recommendations for FV intake and awareness of diseases related to FV intake among men, explaining half of the variation in FV intake between men and women (35). Health believes and dieting have also been reported to explain some of these differences in FV intake (36).

The gender differences in eating behaviors are also evident among children and adolescents indicating that these differences are initiated early in life. A study on FV intake among Norwegian adolescents showed that preferences for FV and perceived accessibility of FV at home explained most of the variation in FV intake between boys and girls (37).

All though only a few studies have been exploring potential reasons for the gender differences in food preferences and eating behaviors, several hypotheses on these differences have been posted. An evolutionary hypothesis based on that men were hunters and women were gatherers suggests that these roles between the genders may also have been reflected in their 
eating behaviors and food preferences, explaining some of the gender variations observed in the current dietary patterns (38). Another hypothesis is that physiologically, boys having a higher energy requirement may explain why they are more drawn towards more energy-dense foods compared to girls (39). The gender disparities in food choices have also been hypothesized to be a result of girls tending to be more prone to social desirability as they are more likely to attach a greater importance to the diet $(34 ; 36)$. Their perception of the diet may also be linked to that in most cultures girls have traditionally been more involved in food preparation and cooking and that this may therefore add to their skills and health-related knowledge in association to nutrition and diet.

\subsection{Determinants of health related behaviors}

In order to understand eating behaviors we need to identify factors which are associated with a specific behavior. By identifying the most important factors/determinants of a behavior we can tailor interventions to improve the selected behavior more efficiently. However, in order to change a behavior, the determinants of the behavior targeted in the intervention needs to be changeable. Frameworks such as the social cognitive theory (SCT) and theory of planned behavior (TPB) have been developed to guide the search for potential determinants of behaviors. The SCT postulates that the personal, behavioral and environmental determinants of a behavior reciprocally influence each other (40). The TPB proposes that a behavior may be predicted by the intentions to perform a specific behavior and further that the intentions are influenced by the attitudes towards the behavior, the subjective norms and the perceived behavioral control of a behavior (41). Some of the determinants included in these theories are personal factors such as knowledge, attitudes, self-efficacy, intentions, preferences and perceived barriers as well as factors related to the perceived social and physical environment such as subjective norms/modeling and availability and accessibility. 
Attitudes are assessed to find out whether there is a positive or negative association in relation to the behavior (i.e. eating FV) which can predict the behavior. Preferences, i.e. how much they like a specific food, has been reported to be one of the strongest predictors of food choices (42-44). Subjective norms are reflecting the perceived social pressure by family and peers to engage or not in a specific behavior (i.e. eating FV). This term is closely related to modeling which means how family and peers may function as role models in specific behaviors that the children/adolescents may try to copy. The availability of foods refers to whether the food of interest is present in the environment, (i.e. in the refrigerator at home). Accessibility, however, refers to how accessible the food is (i.e. placed or prepared in a way that makes it easy/ready to eat). An example of availability would be having carrots in the refrigerator at home. This might not necessarily increase the intake of carrots among the children and/or adolescents. Taking the carrots out of the refrigerator, cutting them and placing them on a table would be an example of making the carrots more accessible for the children and/or adolescents and enhance the consumption of carrots.

\subsection{The Norwegian School Fruit Programme}

The Norwegian authorities have tried to increase the intake of FV among children and adolescents by making it more available at school. One of the Norwegian governments' efforts to do so was to initiate a subscription program of FV at schools among 1-10 graders in 1993. In 2003, the program was made nationwide in collaboration with the Norwegian Marketing Board of Fruit and Vegetables. The program provided the pupils with one piece of fruit or vegetable per day at school in relation to lunch. The schools decided whether to participate in the program or not and the parents of the pupils whether to subscribe or not. The costs of the subscription was subsidised by the government with 1 Norwegian Krone (NOK) per day and the remaining costs $(2.50 \mathrm{NOK}$ per day, equal to approximately $€ 0.30)$ were 
covered by the parents. From the fall of 2007, an officially free school fruit program (no parental payment) was implemented in all secondary (grades 8-10) and combined schools (grades 1-10) in Norway. The subscription program (parental payment) still runs in the primary schools (grades 1-7). In September 2008 when the second cohort of the FVMM project was initiated, 5 of the schools included participated in the free school fruit program, 10 of the schools participated in the subscription program and 12 schools did not participate in any official school fruit program.

\subsection{Research aims}

The overall aim of this thesis was to study gender and socioeconomic disparities in eating behaviors and in determinants of eating behaviors among Norwegian pupils.

The specific aims were:

Paper I

1) to assess the adolescents' eating/drinking behaviors of a selection of healthy (fruit, vegetables and water) and unhealthy (instant noodles, sweet bakery, candy/chips, soft drinks) food items at school, 2) to assess gender and socioeconomic variations in these eating behaviors and 3) to assess variations in these consumption patterns between the schools.

\section{Paper II}

1) to evaluate the effect of the nation-wide implementation of the free school fruit program on adolescents' FV intake and 2) to study the effect of the efforts in relation to gender and socioeconomic status. 


\section{Paper III}

1) to compare FV intake among Norwegian $6^{\text {th }}$ and $7^{\text {th }}$ graders in 2001 and in 2008,2 ) to explore potential mediated effects of accessibility and preferences on changes in FV intake over time, 3) to explore whether these changes in FV intake was moderated by gender and/or socioeconomic status and 4) whether a moderated effect in the FV intake was mediated by accessibility and preferences of FV.

\section{Paper IV}

1) to explore whether home accessibility, modeling, attitudes and preferences can explain the differences in SDC according to gender and the pupils anticipated level of higher education and 2) whether the associations of accessibility, modeling, attitudes and preferences with SDC differ according to gender and level of anticipated further education. 


\section{METHODS}

The present Ph.D. thesis is part of the larger FVMM project. The FVMM project was originally an intervention study with the main aim of increasing school childrens FV intake. The project is three times funded by the Norwegian Research Council.

\subsection{FVMM study design}

The FVMM project was initiated in 2001 by inviting 48 schools from Hedmark and Telemark counties in Norway (24 schools in each county) which were randomly selected to participate in the research project (Table 1). Hedmark and Telemark counties were chosen because the school fruit subscription program was about to start in these two counties in the school year of 2001/02 (in September 2001, no schools had any organized school fruit program at the survey time). From each county 19 schools agreed to participate and out of these 9 schools in each county were randomly selected to serve as intervention schools whereas the remaining 20 schools were control schools. All 6th and 7th graders (age 10-12) in the 38 schools were invited to take part in a questionnaire survey (the baseline survey for Cohort I) before the intervention started.

\begin{tabular}{|c|c|c|c|}
\hline \multicolumn{4}{|c|}{ Table 1 Overview of the number of schools invited and participating in the FVMM study } \\
\hline & $\begin{array}{c}\text { Hedmark county } \\
\text { (n schools) }\end{array}$ & $\begin{array}{c}\text { Telemark county } \\
\text { (n schools) }\end{array}$ & $\begin{array}{c}\text { Total } \\
\text { (n schools) }\end{array}$ \\
\hline Invited schools & 24 & 24 & 48 \\
\hline Participating schools & 19 & 19 & 38 \\
\hline Intervention schools & 9 & 9 & 18 \\
\hline Control schools & 10 & 10 & 20 \\
\hline
\end{tabular}


Two interventions running from October 2001 to April 2002 included the following components: 1) classroom curriculum and newsletters and 2) free participation in the Norwegian School Fruit Programme. All $6^{\text {th }}$ graders at the 18 intervention schools $(n=18)$ participated in the intervention including the classroom curriculum and newsletters. At the 9 intervention schools in Hedmark county all pupils also received the free participation in the Norwegian School fruit Programme. There were therefore three different intervention groups to study: 1$)$ pupils only participating in intervention 1 ( $6^{\text {th }}$ graders in Telemark), 2) pupils participating in both interventions 1 and $2\left(6^{\text {th }}\right.$ graders in Hedmark) and 3$)$ pupils only participating in intervention 2 ( $7^{\text {th }}$ graders in Hedmark).

\subsection{Data collections}

\subsubsection{Data collection procedures}

Data were collected by questionnaires assessing intake of the selected foods, potential determinants of consumption patterns, gender and socioeconomic indicators. The baseline (2001 and 2008) and the follow-up 1 to 3 (2002, 2003 and 2005) survey questionnaires were completed by the pupils in the classroom in the presence of a trained project worker. One school-lesson (45 minutes) was used to complete these questionnaires. At the baseline surveys in 2001 and 2008 the pupils were also given a parent questionnaire to be brought home and completed by one of their parents. In the fourth follow-up survey in 2009 , the questionnaires were mailed to the participants and completed at home.

\subsubsection{Existing data}

School-based questionnaire surveys were conducted by research staff travelling to the schools. The baseline survey was conducted in September 2001 before the interventions was 
initiated. After the intervention ended three follow-up surveys were conducted in May 2002, May 2003 and May 2005. A fourth follow-up survey was conducted in September 2009 (see 2.2.3.1) and a second baseline survey (cohort II) was conducted in 2008 (see 2.2.3.2). The data collections of the FVMM study, with number of participants, are presented in table 2.

Table 2 gives an overview of the timing, sample sizes and mean age of the participants in all of the surveys included in the FVMM study.

Table 2 Overview of the timing, sample size and mean age of the participants included in the FVMM studies

\begin{tabular}{|c|c|c|c|c|c|c|}
\hline & & Baseline & Follow-up 1 & Follow-up 2 & Follow-up 3 & Follow-up 4 \\
\hline \multirow{3}{*}{$\begin{array}{l}\text { FVMM } \\
\text { Cohort I }\end{array}$} & $\begin{array}{c}\text { Time } \\
\text { (mean age) }\end{array}$ & $\begin{array}{c}\text { Sept.2001 } \\
(11.8)\end{array}$ & $\begin{array}{c}\text { May } 2002 \\
\text { (12.5) }\end{array}$ & $\begin{array}{c}\text { May } 2003^{*} \\
(12.0)\end{array}$ & $\begin{array}{c}\text { May } 2005^{\dagger} \\
(15.5)\end{array}$ & $\begin{array}{c}\text { Sept.2009 } \\
(19.8)\end{array}$ \\
\hline & $\mathrm{n}$ & $\begin{array}{l}1950 / \\
1647^{* *}\end{array}$ & 1794 & 1032 & $\begin{array}{l}2870^{\mathrm{a} /} \\
1602^{\mathrm{b}}\end{array}$ & 320 \\
\hline & $\mathrm{n}$ (eligible) & 2287 & & & $\begin{array}{l}3388^{\mathrm{a}} / \\
1950^{\mathrm{b}}\end{array}$ & 1950 \\
\hline \multirow{3}{*}{$\begin{array}{c}\text { FVMM } \\
\text { Cohort } \\
\text { II }\end{array}$} & $\begin{array}{c}\text { Time } \\
\text { (mean age) }\end{array}$ & $\begin{array}{c}\text { Sept.2008 } \\
(11.8)\end{array}$ & & & & \\
\hline & $\mathrm{n}$ & $\begin{array}{l}1339 / \\
996^{* *}\end{array}$ & & & & \\
\hline & $\mathrm{n}$ (eligible) & 1712 & & & & \\
\hline \multicolumn{7}{|c|}{$\begin{array}{l}\text { Data used in the articles of this thesis } \\
{ }^{*} \text { Data collections of this thesis } \\
{ }^{*} \text { Only including initial 6th graders (the 7th graders were in junior high schools and therefore excluded) } \\
{ }^{* *} \text { Number of parents who completed the parent questionnaire } \\
{ }^{\text {a }} \text { Total number of participants (this follow-up also includes pupils who were not participating at baseline) } \\
\text { b Number of participant from the original cohort I }\end{array}$} \\
\hline
\end{tabular}




\subsubsection{New data collections}

\subsubsection{Fourth follow-up survey of cohort I}

In September 2009 a fourth follow-up survey was conducted. The participants were no longer in school, and pupils participating in the 2001 baseline study were contacted by ordinary mail. Totally we received completed questionnares from 320 participants, a response rate of only $16 \%$. We planned to use data from this survey for longitudinal analyses in paper IV, but due to the low participation rate we decided not to include the data.

\subsubsection{Baseline survey of cohort II}

The 38 schools that participated in 2001 (cohort I) were contacted again in 2008 and invited to once more participate in a similar survey. At that time 27 schools agreed to participate, and all 6 th and 7 th graders in these 27 schools were invited to participate in the survey (Cohort II). Similar to the 2001 baseline survey the 2008 baseline survey was also conducted in September. In September 2008, 5 of the schools participated in the free school fruit program (schools with grades 1-10), 10 of the schools participated in the subscription program and 12 schools did not participate in any official school fruit program.

\subsection{The study samples used in this Ph.D. thesis}

The analyses in the papers of this thesis includes the study samples of the 2001 baseline survey (cohort I), the follow-up 3 survey of 2005 (cohort I) and the baseline survey of 2008

(cohort II). In 2001, the pupils were in $6^{\text {th }}$ and $7^{\text {th }}$ grade. A total of 1950 pupils (response rate $85 \%$ ) completed the questionnaire and brought home a parent questionnaire to be completed by one of their parents. For 1647 of these pupils one of their parents completed the parent questionnaire. In 2005 the pupils were in $9^{\text {th }}$ and $10^{\text {th }}$ grade. The study sample of 2005 also 
included 'new' pupils who had not participated in the baseline study of 2001 . The criteria for the inclusion of 'new' pupils was that if the old FVMM pupils constituted more than $30 \%$ of the $9^{\text {th }}$ and $10^{\text {th }}$ grade at the secondary schools, then all $9^{\text {th }}$ and $10^{\text {th }}$ graders at these schools were invited to participate. If not, only the original FVMM pupils participating in 2001 would have been invited. A total of 2870 pupils (response rate $84 \%$ ) completed the questionnaire in 2005. For the baseline study of cohort II in 2008 a total of 1339 pupils (response rate $78 \%$ ) and 996 parents completed the questionnaires.

The FVMM study was conducted according to the guidelines laid down in the Declaration of Helsinki. Ethical approval and research clearance was obtained from The National Committees for Research Ethics in Norway (for the original intervention study including the baseline, follow-up 1 and follow-up 2 surveys) and from The Norwegian Social Science Data Services (all surveys). Written informed consent was obtained from all subjects.

\subsection{Research instruments}

\subsubsection{Eating/drinking at school (paper I)}

The pupils intake at school of a selection of healthy (FV and water) and unhealthy (instant noodles, sweet bakery, candy/chips and soft drinks) food items were assessed by FFQs. The food items were assessed by the following questions: "How often do you eat/drink ... at school?". The questions had seven response alternatives ranging from "every school day" to "never". All variables were dichotomised to less than once per week and once per week or more. Less than once per week was seen as acceptable consumption frequency of the unhealthy food items and as a low consumption frequency of the healthy food items at school. 


\subsubsection{Fruit and vegetable intake (papers II and III)}

The pupils' FV intake was assessed in the questionnaire both by a 24-h recall (paper II) and food frequency questions (FFQ) (papers II and III). The 24-h recall was used to study differences between groups while the FFQ's were used to rank the individuals according to their intake.

The 24-h recall was read aloud to the pupils by a project worker. FV intake the previous day was recorded for school days (i.e., the survey was conducted on weekdays, Tuesday through Friday). The 24-h recall separated the day into five time periods (before school, at school, after school, at dinner, and after dinner). The pupils recalled the types of FV they ate at the different time periods in household measures (e.g., one apple, 12 grapes) or in portions (e.g., one portion of mixed green salad). The household measures were coded into portions/day, and one portion was set at about 80 grams ranging from 65 grams (one carrot), to 105 grams (one apple/one orange). The conversions from household measures to portions were based on household measures and food weights published by The Norwegian National Association for Nutrition and Health. Juices and potatoes were not included in the fruit and vegetable calculations.

The FFQ's used in paper III consisted of four frequency questions including: 1) "How often do you eat vegetables for dinner?”, 2) “...other vegetables (i.e., carrot for schools lunch)?”, 3) “...apples, oranges, pears or bananas?” and 4) “...other fruits or berries?”. The response categories for all questions had 10 response alternatives ranging from "never" $(=0)$ to "several times per day" $(=10)$ and the scale ranged from 0 to 40 times per week. The FFQ used in paper II was one question about the pupils FV intake at school: "How often do you eat fruits and/or vegetables at school?". The variable was dichotomised to eating FV at school 4 or 5 times per week or less. Eating FV at school 4 or 5 times per week was interpreted as eating FV at school on most school days. 


\subsubsection{Determinants of fruit and vegetable intake (paper III)}

The potential determinants of FV intake, accessibility and preferences, were assessed by five and four statements, respectively. Accessibility were assessed by the following statements: 1) "At home we usually have fruits and vegetables in the refrigirator", 2) "At home I am allowed to eat fruit and vegetables whenever I want", 3) "Mother and father do smonetimes cut fruits and vegetables for me as a snack", 4) "At home we usually have vegetables for dinner every day" and 5) "At home we usually have fruits and vegetables available in a (fruit-) bowl”. Preferences were assessed by the following statements; 1) "Fruits and vegetables makes my meals taste better", 2) "I really like raw vegetables", and 3) "Fruits are among the best (foods) I know" and 4) "Fruits and vegetables are very suitable as snacks". The response alternatives for all the statements ranged from "I fully disagree" (=-2) to "I fully agree" (=2), giving scales ranging from -10 to 10 for accessibility and from -8 to 8 for preferences.

\subsubsection{Sugar-sweetened soft drink consumption (paper IV)}

SDC was assessed by one FFQ: "How often do you drink soft drinks?". The question had 10 response alternatives, and scales, ranging from "never" $(=0)$ to "several times per day" $(=10)$.

\subsubsection{Determinants of sugar-sweetened soft drink consumption (paper IV)}

The potential determinants of SDC, accessibility, modeling, attitudes and preferences were assessed by several questions/statements in the questionnaire. Accessibility was assessed by three questions: 1) "How often are soft drinks to be found in your home?", 2) "How often are you served soft drinks for dinner?" and 3) "How often does your mother/father serve you soft drinks besides dinner?". Modeling was assessed by four statements: 1) "How often does your mother/father/siblings/best friend drink soft drinks?". All the questions on both assessibility 
and modeling had 10 response alternatives ranging from "never" $(=0)$ to "several times per day" (=10). Attitudes were assessed by three statements: 1) "Soft drinks are well suited at meals", 2) "Soft drinks are well suited as a thirst-quencher" and 3) "Soft drinks are good for your health". For all statements on accessebility there were 5 response alternatives ranging from "I totally disagree" (=-2) to "I totally agree" (=2). Preference was assessed by one question: "On a scale from 0 to 10 , how tasty do you find soft drinks?". The scales of the potential determinants ranged from 0 to 10 for accessibility, modeling and preferences, and from -2 to 2 for attitudes.

\subsubsection{Socio demographics}

The pupils reported their own gender. As indicators of SES, the parents educational level was assessed individually by the parent recording their own level of educational in the parent questionnaire (paper II and III). This variable was dihotomized into lower education (no university or college) or higher education (unviersity or college). In the 2005 follow-up the pupils were asked to indicate their plans for further education after graduation from secondary school (paper I and IV). The response categories were: "university or college”, "technical or vocational education", "no further education" and "others". This variable was dichotomized into university/college or not.

An overview of the statements and questions used to assess all the variables described above (2.5.1-2.5.6) are given in appendix 1 . 


\subsection{Statistical analyses}

In paper I-IV several different statistical analyses were applied in order to explore the study aims.

The descriptive data presented were obtained by using general descriptive statistics (paper II and IV), t-test (paper II), chi-square (paper II) and one-way ANOVA's (paper III).

For the main analysis conducted in paper I logistic regression models were used to estimate OR's of the pupils consumption of a selection of different foods, and the proportional school variation in these intakes (paper I)

In paper II, III and IV linear regression models were used to explore the effect of the school fruit programs from 2001 to 2008 (paper II), the potential mediators and moderators of SDC (paper IV) and FV intake (paper III). The mediation analyses also included estimating the mediated effect by using the product-of-coefficient method (paper III and IV) and Sobel's test for calculating the significance of the mediated effect (paper III).

All analyses were adjusted for school as a random effect.

The statistical programs MLwiN and SPSS were used.

More detailed descriptions of the statistical analyses are given in the papers (I-IV). 


\section{RESULTS}

\subsection{Paper I: Healthy and unhealthy eating at lower secondary school in Norway}

The aims of this paper were to assess the adolescents' eating/drinking behaviors of a selection of healthy (fruit, vegetables and water) and unhealthy (instant noodles, sweet bakery, candy/chips, soft drinks) food items at school, to assess gender and socioeconomic variations in these eating behaviors and to assess variations in these consumption patterns between the schools.

The proportion of pupils reporting to eat FV at school at least once a week was low (40\%) while the percentages of pupils consuming unhealthy foods such as snacks (33\%), sweet bakery (36\%) and regular soft drinks (24\%) at school at least once a week were relatively high.

Girls and pupils with plans of higher future education reported consumption of healthier foods more often and unhealthy foods less often at school compared to boys and pupils without plans of higher education. The OR's $(95 \% \mathrm{CI})$ for boys compared to girls for consumption at school was $0.29(0.23-0.36)$ for FV and 5.47 (4.14-7.23) for regular soft drinks. The same numbers for adolescents with plans of higher education compared to adolescents without plans of higher education were $1.65(1.33-2.05)$ and 0.43 (0.29-0.64), respectively.

There were large differences in consumption of the selected foods between the schools. E.g. the proportion of pupils consuming candy/chips at school once a week or more ranged from $9 \%$ to $93 \%$ and for soft drinks the proportions ranged from $6 \%$ to $67 \%$. The variance of consumption of the selected food items at school that was attributed to the school level ranged from explaining $3.4 \%$ (diet soft drinks) to $30.7 \%$ (instant noodles) of the variation.

At school level, consumption of candy/chips, sweet bakery and both regular- and diet soft drinks were all significantly correlated to each other, i.e. at schools where there was a high 
proportion of pupils drinking soft drinks there was also a high proportion of pupils eating candy and sweet bakery (Spearman's r 0.37-0.76, all p-values less than 0.05).

\subsection{Paper II: Effect of the nationwide free school fruit scheme in Norway}

The main objective of this study was to evaluate the effect of the nation-wide implementation of the free school fruit program on adolescents' FV intake, comparing Cohort I (2001) with Cohort II (2008). In addition, the effect of the efforts was assessed in relation to gender and SES.

The FV intake at school in general increased from 0.36 portions/school day in 2001 to 0.71 portions/school day in 2008. There was also an increase in all day FV consumption (from 2.45 to 3.07 portions/day), and the proportion of pupils reporting to eat FV at school four or five days a week (from $29 \%$ to $59 \%$ ).

The increase in FV intake was largest within the schools that had been included in the national free school fruit program ( 0.49 portions per school day), followed by the schools participating in the subscription program ( 0.29 portions per school day) and the smallest increase was observed within the schools which did not take part in any of the governmental efforts to increase FV intake at school ( 0.18 portions per school day).

The effects appear to be due to an increase in fruit intake only. There were no significant differences in the change in vegetable intake between the groups from 2001 and 2008.

No significant third-order interactions (time*group*gender or time*group*parental education level) were found, indicating that the effect of the school fruit programs was not different for girls versus boys or for those pupils with parents of higher education level versus those of parents with lower education level. E.g. the change in percentage points from 2001 to 2008 in the proportion of pupils in schools included in the national free fruit scheme eating FV at 
school 4 or 5 days per week were 61 for boys and 50 for girls. The same figures for pupils of parents with lower education level compared to pupils of parents with higher educational level were 52 and 60 , respectively.

\subsection{Paper III: Changes in 10-12 year old's fruit and vegetable intake in Norway from} 2001 to 2008 in relation to gender and socioeconomic status - a comparison of two crosssectional groups

The main objectives of this study were to 1) compare FV intake among Norwegian $6^{\text {th }}$ and $7^{\text {th }}$ graders in 2001 and 2008, to 2) explore potential mediated effects of accessibility and preferences on changes in FV intake over time, to 3) explore whether these changes in FV intake was moderated by gender and/or SES and 4) whether a moderated effect in the FV intake was mediated by accessibility and preferences of FV.

A decrease in FV intake (from 14.2 times/week to 13.9 times/week, $p=0.06$ ) and an increase in the mean scores of both accessibility and preferences were observed from 2001 to 2008 . The decrease in FV intake was suppressed by accessibility and preferences, i.e. the decrease in FV intake would have been larger if the pupils' perceived accessibility and preferences for FV over time had not increased.

A significant interaction was found between time and parental education level indicating that the changes FV intake over time were moderated by parental education level. Subgroup analysis showed an increase in the SES disparities where the pupils of parents with lower education level had a decline in FV intake (from 13.9 times/week in 2001 to 12.6 times/week in 2008) whereas the pupils of parents with higher educational level had a slight increase in FV intake (from 14.8 times/week in 2001 to 15.0 times/week in 2008). No significant interaction was found between time and gender. 
The increased SES disparity in FV intake was partly mediated by increasing SES disparities in accessibility and preferences, where the high SES group had a steeper increase in accessibility and preferences over time compared to the low SES group. Again, the increase in accessibility and preferences suppressed the decrease in FV intake.

\subsection{Paper IV: Predictors and mediators of differences in soft drink consumption according to gender and plans of further education among Norwegian secondary schoolchildren}

The aims of this study were to explore whether accessibility, modeling, attitudes and preferences can explain the differences in SDC according to gender and the pupils plans of further education and to explore whether the associations of accessibility, modeling, attitudes and preferences with SDC differ according to gender and level of anticipated further education.

The overall association between gender and SDC confirmed that girls had 1.6 times per week $(95 \% \mathrm{CI}=-1.30--0.08)$ lower consumption frequency than boys. The strongest single mediators for gender differences in SDC were attitudes (explaining 57\%) and preferences (explaining 51\%). Combined, the mediators explained $63 \%$ of the gender variation in SDC.

The overall association between future education plans and SDC showed that pupils planning to enroll in higher education reported a 0.69 times per week $(95 \% \mathrm{CI}=-0.93--0.45)$ lower frequency of consumption compared to adolescents without higher education plans. The strongest single mediators for differences in future education plans were accessibility (explaining 69\%) and modeling (explaining 44\%). Together, the mediators explained $80 \%$ of the variation in SDC according to future education plans. 
Significant interactions between gender and accessibility, gender and modeling, and gender and attitudes were observed. Stratification by gender showed that the association between attitudes and SDC was stronger among girls. The associations of accessibility and modeling with SDC were stronger for boys. Significant interactions between future education plans and modeling, future education plans and attitudes and future education plans and preferences were observed. Stratification by educational plans showed that the association between modeling and SDC was stronger among pupils with plans of future higher education. The associations of attitudes and preferences with SDC were stronger among pupils without plans of higher education.

However, all moderating effects were small indicating that interventions on reducing SDC in this age group can target the same mediators for both boys and girls and pupils with different levels of future educational plans. 


\section{DISCUSSION}

\subsection{Discussion of the results}

The overall aim of this thesis was to study gender and socioeconomic disparities in eating behaviors and in determinants of eating behaviors among Norwegian pupils.

\section{Cross sectional disparities in eating behaviors (paper I and IV)}

Our results show that there are large gender differences in eating behaviors. According to the Norwegian national recommendations on dietary intake the girls in our study samples had more healthy eating behaviors compared to the boys (paper I and IV). The girls consumed healthy food items such as FV more often than boys (paper I), whereas the boys consumed unhealthy food items such as soft drinks more often than girls (paper I and IV). These results confirm what has been found in other studies regarding gender differences in eating behaviors. Within the FVMM project these gender differences has previously been found both in daily SDC (10) and FV intake (37), and in the pupils intake of healthy and unhealthy foods at school (paper I). Another Norwegian study among 8817 Norwegian adolescents aged 1319 years also found that the girls had a higher FV intake and lower SDC compared to the boys (28).These trends were also confirmed in a European study including school-aged children from 28 countries (45). A review of FV intake among children and adolescents by Rasmussen et.al reported that in 27 out of 49 studies on gender differences in FV intake, girls had a higher or more frequent FV intake compared to boys. The review further reported that these gender differences in FV intake seemed more profound in European countries than in the US (27).

Socioeconomic differences in eating behaviors were also observed in our studies. Pupils of parents with lower educational level had less healthy eating behaviors (i.e. higher or more 
frequent SDC and lower or less frequent FV intake) compared to pupils of parents with higher educational level according to the national dietary guidelines. The same trends were observed when using the pupils' plans of further education after secondary school as an indicator of socioeconomic position (paper IV). The socioeconomic differences in SDC showed that pupils with plans of higher future education consumed soft drinks less often than pupils without higher education plans. These findings on SES disparities are consistent with previous findings from the FVMM study regarding both daily SDC (10), FV intake (46) and consumption of healthy and unhealthy foods at school (paper I), confirming what has been reported in other literature. The review by Rasmussen et.al (27) on FV intake among children and adolescents also reported that their FV intake was all over, regardless of type of indicator for SES assessed, strongly associated with SES. All studies included in the review which used parental education level as an indicator for SES showed that children and adolescents of parents with higher education had a higher or more frequent $\mathrm{FV}$ intake compared to children and adolescents of parents with lower education (27).

Our results showed that these gender and socioeconomic differences in eating behaviors were also evident among the children at school. Paper I showed that girls and pupils planning higher education had a higher consumption of more healthy food items and lower consumption of unhealthy food items at school compared to boys and pupils not planning higher education (paper I).

\section{Changes in gender and SES disparities over time (paper III)}

We found that there had been a significant increase from 2001 to 2008 in the SES disparity in FV intake. The results showed that the low SES pupils had a steeper decline in FV intake from 2001 to 2008 compared to the high SES pupils. The gender disparity in FV intake however, did not significantly change for the same period (paper III). An indication of the 
same trend in SES was seen in our second paper among pupils attending schools which did not offer any school fruit program. We found that the percentage change in pupils consuming FV 4 or 5 days per week at school from 2001 to 2008 was unchanged ( $0 \%$ ) among the low SES pupils whereas pupils in the high SES group had an increase in their FV intake by $12 \%$ point during the same period (paper II). However, these differences were not tested statistically. To our knowledge there are few studies which have explored the gender or SES disparities in eating behaviors within the same age group over time. An unpublished study among Dutch children by Fischer et al showed that girls of lower educated mothers had a lower fruit intake in 2009 compared to 2003 (unpublished work by Fischer C, Brug J, Tak N and Te Velde S). There are however studies which have found that the eating behaviors tend to become less healthy (16) and that the FV intake tend to decrease as the adolescents get older (46). It is difficult to state whether this is due to aging or to a trend in the society. Our findings indicate that there seem to be a trend in society where children and adolescents of lower SES consume less FV with time (in the period from 2001 to 2008).

\section{Gender and SES effects of the intervention (paper II)}

In contrast to our findings in paper III we found that the school fruit programs evaluated in paper II did not show any significant interaction between time* group*parental education level and the effect of the school fruit programs were not significantly different for pupils of parents with lower educational level compared to pupils of parents with higher educational level. A potential reason why the effect of the school fruit programs were not seen in the development of SES disparity in this paper might be that only a few school received the free school fruit, diluting the effect. However, it might also be an issue of statistical power, lacking the effect of finding a significant third order interaction. In paper II there was a not significant interaction between time*group*gender indicating that the efforts of the government was not 
different for boys and girls. Over time, from 2001 to 2008 we found that the gender disparity in FV intake was stable (paper III). A recent review by Yildirim et.al included 46 studies on testing gender as a potential moderator in school based energy balance behavior interventions. They found that girls in general responded better to interventions compared to boys except for in interventions targeting reducing sedentary behavior and sugar intake. This was not the case for the school fruit interventions evaluated in paper II. The review showed that girls especially responded well to interventions on reducing fat intake. However, SES was not a significant moderator of many of the intervention outcomes in this review (47).

\section{Gender and SES differences in determinants/mediators (paper III and IV)}

The gender and SES differences were also observed regarding the determinants of SDC and FV intake such as perceived accessibility at home, attitudes, modeling and preferences. We found that boys and low SES pupils had higher scores compared to girls and high SES pupils on all the potential mediators assessed in relation to SDC (paper IV). Our results also showed that the high SES pupils had a steeper increase in perceived accessibility at home and preferences of FV from 2001 to 2008 compared to the low SES pupils (paper III). The gender and SES differences observed in the determinants indicate that they may also be mediators of the behavior, i.e. that they explain the observed gender and SES differences in eating behaviors. The third paper showed that the increased SES disparity from 2001 to 2008 in FV intake was indeed partly mediated (suppressed) by an increase in SES disparities in accessibility and preferences (paper III). In the fourth paper the results showed that the differences in SDC was strongly associated gender differences in attitudes and preferences and SES differences in accessibility and modeling (paper IV).

Gender and SES differences in determinants of FV intake among pupils have previously been explored in the FVMM study showing that the gender differences in preferences of FV 
appeared to be the main reason why boys eat less FV - i.e. girls like FV more than boys. This study also reported that differences in perceived accessibility of FV at home also explained some of the gender differences (37). Another FVMM study on SES differences in FV intake showed that from perceived accessibility at home, modeling, intention, preferences, selfefficacy and knowledge, accessibility appeared to be the strongest mediator of the differences in FV intake between the high and low SES groups. I.e. the pupils of parents with higher education level consumed more FV because they had more access to FV at home (46).

\subsection{Methodological considerations}

\subsubsection{Design of the study}

Initially, the FVMM project was designed as an intervention study. Out of 38 schools in 2001 9 schools were included in the intervention where the pupils received one piece of free school fruit per school day for one school year. In addition, 9 schools participated in a FV subscription program (48). Also, $6^{\text {th }}$ graders in 18 schools received an FV educational program (49). At the follow-up in 2005 also 'new' pupils who had not participated in the baseline study of 2001 were included. The inclusion criteria for the 'new' pupils was that if the old FVMM pupils constituted more than $30 \%$ of the $9^{\text {th }}$ and $10^{\text {th }}$ grade at the secondary schools, then all $9^{\text {th }}$ and $10^{\text {th }}$ graders at these schools were invited to participate. This made the design of the study rather complicated. In paper I and IV we used data from the third follow-up in 2005 , and we used the full study sample (i.e. both control, intervention and 'new' pupils) in order to achieve the greatest statistical power. Theoretically, the effect of the intervention may have influenced the results of these two papers. However, the analyses were also run on the control pupils only, and no substantial differences were observed when comparing these results. 
Paper I and IV are based on cross sectional data from the third follow-up survey in 2005.

Cross-sectional studies can only consider associations but not state any directional or causal paths. In order to explore directional and causal paths longitudinal studies are needed. The fourth follow-up survey of cohort I was conducted during the fall of 2009. Due to the participants being out of school, and thereby hard to reach as a group, the survey was done by sending the participants the questionnaire by ordinary mail to be completed at home. The response rate of this follow-up was low, only $16 \%$. This caused us to leave out data from this follow-up in our analysis and alter some of the original plans of doing longitudinal analysis.

\subsubsection{Questionnaire/instrument}

A variety of dietary assessment methods to estimate the average daily intake among individuals have been developed (50). The most appropriate method to be used depends on the purpose of the study, information needed and the study sample. In larger studies most of the dietary assessment methods used are self-reported due to limited resources available. Among the most widely used self-reported methods are dietary records, FFQ's and 24-h recalls. In the dietary records (also called a food diary) the type and amount of the foods consumed are registered by the participants on a daily basis. The FFQ's are asking the participants about their average intake of selected foods over a specific time period (i.e. 3 months back in time) and have fixed response categories. The 24-hour recalls ask about what type and amount of food the participant has eaten the day before. However, when using these assessment methods among children the methods also needs to be carefully tailored the specific age group studied. 
A previous study in the FVMM project tested the reliability and validity of the FFQ and the 24-hour recall developed in the project to a 7-day food diary (reference method) among $6^{\text {th }}$ graders (51). The reliability of both the FFQ's and the 24-hour recall were found to be good, indicating that the children reported consistent intake registered with 14-days apart. The results on validity showed that the FV intake was somehow overestimated by the FFQ's and 24-hour recall compared to the results from the 7-day diary, but the validity was still comparable to similar studies (47). The 7-day diary used as the referent method did however show that the children's FV intake decreased over time (i.e. highest FV intake on the first day and lowered by almost $50 \%$ by the $7^{\text {th }}$ day of recording). Whether this was due to overestimation of their FV intake on the first day of reporting or due to the children getting tired and less accurate in reporting by time is not studied further. However, this should therefore be kept in mind when interpreting the result on the validity of the FFQ's and 24hour recall. The results from the FFQ's and 24-hour recall are further discussed below in relation to the results of this thesis.

Two different methods were used to estimate FV intake - the FFQ and the 24-hour recall. The purpose of the FFQ's was to rank the pupils according to their FV intake whereas the purpose of the 24-hour recall was to measure the effect of the intervention. The use of FFQ's among children has been discussed previously regarding how well this method is to assess dietary intake among children (51). A review by McPherson et al concluded that generally the correlations between validation standards and dietary method were higher for dietary recall and records compared to FFQ's indicating that it might be easier for children to remember what they ate yesterday (as in a 24-hour recall) and/or to keep food diaries rather than to estimate their intake of a specific food item over a period of time in the past (52). However, in our study it was not possible to collect the dietary data we needed by repeated 24-hour recalls or by food diaries due to the large sample size and restricted time and recourses. As 
mentioned earlier, the children completed the questionnaires in the classroom where a project worker was always present and offered to help the children if they needed.

The FFQ's on food items consumed at school have not been validated or tested for reliability. However, our FFQ's on food items consumed at school are similar to the FFQ's on daily FV intake among $6^{\text {th }}$ graders studied by Andersen et al. which showed acceptable results on validity and reliability (51). The variables on perceived accessibility and preferences of FV have been analyzed for reliability and test-retest correlations of 0.66 for accessibility and 0.74 for preferences (53). The validity of the questions on SDC has not been tested. However, based on data from a test-retest study among $6^{\text {th }}$ graders testing the reliability FFQ's (51) a previous study from the FVMM project reported that $80 \%$ of the children were classified into the same category of SDC when assessed twice, with 14 days between the two assessments (10). The potential mediators of SDC were not tested for validity or reliability.

In paper I and IV we used the pupils' plans on future education as an indicator of SES. The main reason for choosing this variable instead of the parents educational level, which may be the most widely used indicator for SES in similar studies, is that it allowed us to include a larger number of pupils in the study sample. Data from this study sample was collected at the third follow-up in 2005. At this follow-up "new" pupils (i.e. pupils at the same secondary schools, but from other elementary schools) who did not complete the baseline questionnaire in 2001 were also included (see 2.4). For these 'new' pupils we did not have data on parental education level as this variable was obtained only from the baseline parental questionnaire in 2001. At the follow-up in 2005 the pupils were $9^{\text {th }}$ and $10^{\text {th }}$ grades and the mean age was 15.5 years. The use of future educational plans as an indicator of SES has previously been shown to be stable among this age group and track well into adulthood (29). 


\subsection{Conclusions}

The results of these studies confirm the previously reported gender and SES differences in eating behaviors among children and adolescents - i.e. girls and pupils of higher SES have more healthy eating behaviors. All though the FV intake among $6^{\text {th }}$ and $7^{\text {th }}$ graders increased from 2001 to 2008 among pupils participating in the national school fruit programs, and no difference in the effect was observed in relation to gender or SES, little change in the FV intake was indicated for low SES pupils not participating in the program. The results also showed that there had been an increase in the social disparity in FV intake from 2001 to 2008 and that this increase in disparity appears to be partly explained by an increased disparity in perceived accessibility at home and preferences of FV among the pupils. The gender and social disparities in SDC among $9^{\text {th }}$ and $10^{\text {th }}$ graders were partly explained by accessibility, modeling, attitudes and preferences. However, lack of substantial moderating effect by gender and SES on these mediators indicates that future interventions targeting these mediators of SDC in order to reduce consumption in this age group do not justify the need of a different approach in the interventions in relation to gender and SES - i.e. not separate interventions for boys and girls or for pupils of high and low SES.

The results of these studies imply that there is still a need for further studies and interventions to understand and improve the children and adolescents eating behaviors, and especially to understand and improve the eating behaviors of boys and low SES pupils. Intervention studies in order to increase accessibility and preferences of FV and decrease accessibility and preferences of SDC are needed. 
(1) World Health Organization. Diet, nutrition and the prevention of chronic diseases. Joint WHO/FAO expert consultation. Technical report series no. 916. Geneva: WHO; 2003.

(2) Nasjonalt råd for ernæring. Kostråd for å fremme folkehelsen og forebygge kroniske sykdommer. Oslo: Helsedirektoratet; 2011.

(3) Elmadfa I. European Nutrition and Health Report 2009. Forum of Nutrition. Vol. 62. Vienna: Karger; 2009.

(4) Wolf A, Yngve A, Elmadfa I, Poortvliet E, Ehrenblad B, Perez-Rodrigo C, et al. Fruit and vegetable intake of mothers of 11-year-old children in nine European countries: The Pro Children Cross-sectional Survey. Ann Nutr Metab 2005 Jul;49(4):246-54.

(5) Andersen LF, Overby N, Lillegaard IT. [Intake of fruit and vegetables among Norwegian children and adolescents]. Tidsskr Nor Laegeforen 2004 May 20;124(10):1396-8.

(6) Overby NC, Lillegaard IT, Johansson L, Andersen LF. High intake of added sugar among Norwegian children and adolescents. Public Health Nutr 2004 Apr;7(2):285-93.

(7) Nielsen SJ, Popkin BM. Changes in beverage intake between 1977 and 2001. Am J Prev Med 2004 Oct;27(3):205-10.

(8) French SA, Lin BH, Guthrie JF. National trends in soft drink consumption among children and adolescents age 6 to 17 years: prevalence, amounts, and sources, 1977/1978 to 1994/1998. J Am Diet Assoc 2003 Oct;103(10):1326-31.

(9) Kerr MA, Rennie KL, McCaffrey TA, Wallace JM, Hannon-Fletcher MP, Livingstone MB. Snacking patterns among adolescents: a comparison of type, frequency and portion size between Britain in 1997 and Northern Ireland in 2005. Br J Nutr 2009 Jan;101(1):122-31.

(10) Bere E, Glomnes ES, te Velde SJ, Klepp KI. Determinants of adolescents' soft drink consumption. Public Health Nutr 2008 Jan;11(1):49-56.

(11) Naska A, Bountziouka V, Trichopoulou A. Soft drinks: time trends and correlates in twentyfour European countries. A cross-national study using the DAFNE (Data Food Networking) databank. Public Health Nutr 2010 Sep;13(9):1346-55.

(12) Stea TH, Overby NC, Klepp KI, Bere E. Changes in beverage consumption in Norwegian children from 2001 to 2008. Public Health Nutr 2011 Aug 11;1-7.

(13) Sosial- og helsedirektoratet. Sosial- og helsedirektoratets handlingsplan mot sosiale ulikheter i helse - Gradientutfordringen. Oslo: Sosial- og helsedirektoratet; 2005.

(14) Savage JS, Fisher JO, Birch LL. Parental influence on eating behavior: conception to adolescence. J Law Med Ethics 2007;35(1):22-34.

(15) DiMeglio G. Nutrition in adolescence. Pediatr Rev 2000 Jan;21(1):32-3. 
(16) Lien N, Lytle LA, Klepp KI. Stability in consumption of fruit, vegetables, and sugary foods in a cohort from age 14 to age 21. Prev Med 2001 Sep;33(3):217-26.

(17) te Velde SJ, Twisk JW, Brug J. Tracking of fruit and vegetable consumption from adolescence into adulthood and its longitudinal association with overweight. Br J Nutr 2007 Aug;98(2):431-8.

(18) Drieskens S, Van OH, Demarest S, Van der HJ, Gisle L, Tafforeau J. Multiple risk behaviour: increasing socio-economic gap over time? Eur J Public Health 2010 Dec;20(6):634-9.

(19) Skodova Z, Nagyova I, van Dijk JP, Sudzinova A, Vargova H, Studencan M, et al. Socioeconomic differences in psychosocial factors contributing to coronary heart disease: a review. J Clin Psychol Med Settings 2008 Sep;15(3):204-13.

(20) Krieger N. Defining and investigating social disparities in cancer: critical issues. Cancer Causes Control 2005 Feb;16(1):5-14.

(21) Brown AF, Ettner SL, Piette J, Weinberger M, Gregg E, Shapiro MF, et al. Socioeconomic position and health among persons with diabetes mellitus: a conceptual framework and review of the literature. Epidemiol Rev 2004;26:63-77.

(22) McLaren L. Socioeconomic status and obesity. Epidemiol Rev 2007;29:29-48.

(23) Holmboe-Ottesen G., Wandel M, Mosd $\varnothing \mid$ A. Social inequality and diet. Tidsskr Nor Laegeforen 2004;11(124):1526-8.

(24) Drewnowski A, Darmon N, Briend A. Replacing fats and sweets with vegetables and fruits--a question of cost. Am J Public Health 2004 Sep;94(9):1555-9.

(25) Ball K, Crawford D, Mishra G. Socio-economic inequalities in women's fruit and vegetable intakes: a multilevel study of individual, social and environmental mediators. Public Health Nutr 2006 Aug;9(5):623-30.

(26) Hanson MD, Chen E. Socioeconomic status and health behaviors in adolescence: a review of the literature. J Behav Med 2007 Jun;30(3):263-85.

(27) Rasmussen M, Krolner R, Klepp KI, Lytle L, Brug J, Bere E, et al. Determinants of fruit and vegetable consumption among children and adolescents: a review of the literature. Part I: Quantitative studies. Int J Behav Nutr Phys Act 2006;3:22.

(28) Nilsen SM, Krokstad S, Holmen TL, Westin S. Adolescents' health-related dietary patterns by parental socio-economic position, the Nord-Trondelag Health Study (HUNT). Eur J Public Health 2010 Jun;20(3):299-305.

(29) Friestad C, Lien N, Klepp KI. Educational plans - when are they established? Implication for the measurement of socio-economic status in youth. Young 20019(2):18-32.

(30) World Health Organization. Media centre. Women's health.Fact sheet N 334. World Health Organization 2009

(31) Statistisk Sentralbyrå. Befolkningsstatistikk. Døde. 2010. Statistisk sentralbyrå 2011 
(32) Statistisk Sentralbyrå. Noregs offisielle statistikk D 411. Dødsårsaker 1996-2006. Oslo Kongsvinger: Statistisk sentralbyrå; 2009.

(33) Roos G, Prattala R, Koski K. Men, masculinity and food: interviews with Finnish carpenters and engineers. Appetite 2001 Aug;37(1):47-56.

(34) Johansson L., Solvoll K. Norkost 1993-94 og 1997. Landsomfattende kostholdsunders $\varnothing$ kelser blant kvinner og menn i alderen 16 til 79 år. Rapport nr. 3/1999. Oslo: Statens råd for ernæring og fysisk aktivitet; 1999.

(35) Baker $\mathrm{AH}$, Wardle J. Sex differences in fruit and vegetable intake in older adults. Appetite 2003 Jun;40(3):269-75.

(36) Wardle J, Haase AM, Steptoe A, Nillapun M, Jonwutiwes K, Bellisle F. Gender differences in food choice: the contribution of health beliefs and dieting. Ann Behav Med 2004 Apr;27(2):107-16.

(37) Bere E, Brug J, Klepp KI. Why do boys eat less fruit and vegetables than girls? Public Health Nutr 2008 Mar;11(3):321-5.

(38) Kaplan H., Hill K., Lancaster J., Hurtado A.M. A theory of human life history evolution: diet, intelligence, and longevity. Evolutionary Anthropology 2000;9:156-85.

(39) Cooke $\amalg$, Wardle J. Age and gender differences in children's food preferences. Br J Nutr 2005 May;93(5):741-6.

(40) Bandura A. Social Foundations of Thought and Action: A Social Cognitive Theory. Englewood Cliffs, NJ: Prentice Hall; 1986.

(41) Ajzen I. The theory of planned behavior. Organ Behav Hum Decis Process 1991;50:179-211.

(42) Brug J, Tak NI, te Velde SJ, Bere E, De B, I. Taste preferences, liking and other factors related to fruit and vegetable intakes among schoolchildren: results from observational studies. $\mathrm{Br} J$ Nutr 2008 Feb;99 Suppl 1:S7-S14.

(43) De B, I, te VS, Brug J, Due P, Wind M, Sandvik C, et al. Personal, social and environmental predictors of daily fruit and vegetable intake in 11-year-old children in nine European countries. Eur J Clin Nutr 2008 Jul;62(7):834-41.

(44) Bere E, Klepp KI. Changes in accessibility and preferences predict children's future fruit and vegetable intake. Int J Behav Nutr Phys Act 2005 Oct 10;2:15.

(45) Vereecken CA, Inchley J, Subramanian SV, Hublet A, Maes L. The relative influence of individual and contextual socio-economic status on consumption of fruit and soft drinks among adolescents in Europe. Eur J Public Health 2005 Jun;15(3):224-32.

(46) Bere E, van LF, Klepp KI, Brug J. Why do parents' education level and income affect the amount of fruits and vegetables adolescents eat? Eur J Public Health 2008 Dec;18(6):611-5.

(47) Yildirim M, van Stralen MM, Chinapaw MJ, Brug J, van MW, Twisk JW, et al. For whom and under what circumstances do school-based energy balance behavior interventions work? Systematic review on moderators. Int J Pediatr Obes 2011 Jun;6(2-2):e46-e57. 
(48) Bere E, Veierod MB, Klepp KI. The Norwegian School Fruit Programme: evaluating paid vs. no-cost subscriptions. Prev Med 2005 Aug;41(2):463-70.

(49) Bere E, Veierod MB, Bjelland M, Klepp KI. Outcome and process evaluation of a Norwegian school-randomized fruit and vegetable intervention: Fruits and Vegetables Make the Marks (FVMM). Health Educ Res 2006 Apr;21(2):258-67.

(50) Coulston AM, Boushey CJ. Nutrition in the Prevention and Treatment of Disease, Second Edition. Amsterdam: Academic Press, Elsevier; 2008.

(51) Andersen LF, Bere E, Kolbjornsen N, Klepp KI. Validity and reproducibility of self-reported intake of fruit and vegetable among 6th graders. Eur J Clin Nutr 2004 May;58(5):771-7.

(52) McPherson RS, Hoelscher DM, Alexander M, Scanlon KS, Serdula MK. Dietary assessment methods among school-aged children: validity and reliability. Prev Med 2000;31:S11-S33.

(53) Bere E, Klepp KI. Reliability of parental and self-reported determinants of fruit and vegetable intake among 6th graders. Public Health Nutr 2004 Apr;7(2):353-6. 


\section{PAPER I}

Healthy and unhealthy eating at lower secondary school in Norway 

PAPER II

Effect of the nationwide free school fruit scheme in Norway 



\title{
Effect of the nationwide free school fruit scheme in Norway
}

\author{
Elling Bere ${ }^{1 *}$, Marit Hilsen ${ }^{1,2}$ and Knut-Inge Klepp ${ }^{2}$ \\ ${ }^{1}$ Faculty of Health and Sport, University of Agder, Serviceboks 422, 4604 Kristiansand, Norway \\ ${ }^{2}$ Department of Nutrition, Faculty of Medicine, University of Oslo, Oslo, Norway
}

(Received 11 August 2009 - Revised 11 February 2010 - Accepted 12 February 2010)

In Norway, children and adolescents consume only about half of the national five-a-day recommendation. There are also rather large social inequalities in health, and in eating behaviours. In order to increase fruit and vegetable (FV) intake, a subscription programme was initiated in 1996 and made nationwide in 2003, and a free programme (without parental payment) has been implemented nationwide from 2007. The objective of the present study is to evaluate the effect of these efforts. Pupils in the sixth and seventh grades (age 10-12 years) at twenty-seven schools responded to a questionnaire in $2001(n 1488,85 \%)$ and in $2008(n 1339,78 \%)$. FV intake was measured by a 24-h recall. In 2001, none of the schools had any organised school fruit programme. In 2008, five schools participated in the free school fruit programme, ten schools participated in the subscription programme and twelve schools did not participate in any official programme. The increases in fruit intake at school were $0.49,0.29$ and 0.18 portions/school day, respectively, for the Free Fruit 08 , Subscription 08 and No Programme 08 schools (time $\times$ group $P<0.001$ ), and $0.74,0.39$ and 0.16 portions/d for fruit intake all day (time $\times$ group $P=0.04$ ). No group effect was observed for vegetable intake. There has been an increase in pupils' fruit intake from 2001 to 2008 in Norway, and the school fruit programmes seem to have been effective. A great challenge remains in increasing vegetable intake.

School fruit: Intervention: Fruits and vegetables: Adolescents

A diet high in fruits and vegetables (FV) is inversely related to several chronic diseases ${ }^{(1)}$, and an increased intake would improve global public health ${ }^{(2)}$. In Norway, children and adolescents consume only about half of the national five-a-day recommendation ${ }^{(3)}$. As food preferences and habits established in childhood to a large extent tend to be maintained into adulthood $^{(4,5)}$, and in order to achieve maximum preventive potential, it is important to get children to eat more FV.

The national Norwegian authorities have made considerable efforts to increase school children's FV intake at school over the last few years. A subscription programme for grades 1-10 was initiated in 1996, and was made nationwide in 2003 in collaboration with the Norwegian Marketing Board for Fruits and Vegetables. In this programme, the schools initially choose to participate or not, and then the pupils at the participating schools can decide to subscribe or not. The cost for the parents is currently Norwegian Krone 2.50 per school day (approximately €0.30). The pupils who subscribe receive a piece of fruit or a carrot each school day, usually in connection with their lunch meal. The programme is subsidised by the Norwegian Government with Norwegian Krone 1.00 per pupil per school day.

The subscription programme and a free pilot version of the same programme (without parental payment) were evaluated in the research project Fruits and Vegetables Make the Marks. In a school-randomised trial including thirty-eight schools, a cohort of 1950 pupils (initially in the sixth and seventh grades) was followed from school year 2001/02 to school year 2004/05 (cohort I, Table 1). The results reported were that both programmes increased FV intake, but that the free programme was much more effective than the subscription programme (effect sizes were 0.9 and 0.2 portions/d on FV intake at school, respectively, compared with control schools $)^{(6)}$, and that 1 year of free school fruit also had a positive long-term effect on adolescents' FV intake both at $1^{(7)}$ and 3 years ${ }^{(8)}$ after the end of the free fruit intervention (effect sizes on FV intake all day were about 0.5 and 0.4 portions/d, respectively, compared with control schools). The subscription programme tended to increase social disparities $^{(6,9)}$, while the free fruit pilot programme was effective in increasing FV intake among all groups including boys and children of parents without higher education ${ }^{(6-9)}$.

Only a few similar interventions, providing free or subsidised FV at school, have been evaluated, and their results have been published internationally. Two recent review studies have reported that such interventions in general tend to be effective in increasing pupils' FV intake ${ }^{(10,11)}$.

Despite the Norwegian welfare state and the large Norwegian gross domestic product per capita, there are large social inequalities in health in Norway ${ }^{(12)}$. Social inequalities are also seen in health-related behaviours such as eating behaviours, and among adolescents in Norway, rather large $\operatorname{sex}^{(13)}$ and socio-economic ${ }^{(14)}$ disparities in FV intake have been reported. For example, boys have been reported to eat FV 11.9 times/week, compared with 14.5 times/week for girls ${ }^{(13)}$, and adolescents of parents with higher education 
Table 1. Description of the two different study designs for evaluating different school fruit programmes in Norway (Hedmark and Telemark counties) within the Fruits and Vegetables Make the Marks project: (I) a longitudinal design (cohort I), evaluated by Bere et al. ${ }^{(6-8)}$, and (II) two repeated cross-sectional surveys within the same schools (cohort I $v$. cohort II), which is the study sample of the present study

\begin{tabular}{lll}
\hline $\begin{array}{l}\text { Cohort I } \\
\text { (thirty-eight } \\
\text { schools, } n \text { 1950)* }\end{array}$ & $\begin{array}{l}\text { Cohort II } \\
\text { (twenty-seven } \\
\text { schools, } n \text { 1339) }\end{array}$ \\
\hline Baseline survey 2001 & $\begin{array}{l}\text { Intervention: } \\
\text { Subscription } \\
\text { programme† } \\
\text { Free fruit nationwide }\end{array}$ & First survey 2008 \\
& &
\end{tabular}

Intervention

Subscription

programme†

Free fruit pilot§

Follow-up surveys

$2002^{(6)}, 2003^{(7)}, 2005^{(8)}$

* Of which, twenty-seven schools also participated in the 2008 survey (cohort II). $n 1488$ in these twenty-seven schools.

†The subscription programme (grades 1-10) was initiated in 1996 and made nationwide in 2003. In Hedmark and Telemark counties, this programme was initiated in 2001.

$\S \mathrm{A}$ free fruit programme was implemented nationwide in all secondary elementary schools (grades 8-10) and all combined schools (grades 1-10) in Norway from autumn 2007.

$\ddagger$ A free school fruit pilot programme was implemented within nine elementary schools (grades 1-7) during the school year 2001/02.

have been reported to eat more FV than adolescents of parents without higher education. This disparity is increasing with age, $14.0 v .12 .8$ times/week at age 12.5 years and 15.1 v. 12.7 times/week at age 15.5 years $^{(14)}$. There is a governmental desire to reduce these inequalities, and a free school fruit programme has been suggested as an effective means of achieving this goal since all adolescents attend school ${ }^{(15)}$.

From autumn 2007, an official free school fruit programme (without parental payment) was implemented in all secondary elementary schools (grades 8-10) and all combined schools (grades 1-10) in Norway. Indeed, it is now legally established that all pupils in secondary schools are entitled to a free piece of fruit or vegetable every school day ${ }^{(16)}$. The subscription programme, with parental payment, still runs in primary/elementary schools (grades 1-7). A new repeated cross-sectional survey was conducted within the Fruits and Vegetables Make the Marks project at the same schools in 2008 (cohort II, Table 1), making it possible to evaluate the effect of the nationwide implementation of the free school fruit programme.

The main objective of the present study is to evaluate the effect of the nationwide implementation of the free school fruit programme on adolescents' FV intake by comparing cohort I (2001) with cohort II (2008). In addition, the effect of the efforts will be assessed in relation to sex and socio-economic status.

\section{Experimental methods}

\section{Design and study sample}

In 2001, forty-eight schools from Hedmark and Telemark counties (twenty-four schools in each county) were randomly selected and invited to participate in the research project Fruits and Vegetables Make the Marks, and nineteen schools from each county agreed to participate. All sixth and seventh graders (age 10-12 years) in these thirty-eight schools were invited to take part in a questionnaire survey (which was the baseline survey for cohort I, see Table 1$)^{(6,7,17)}$. These thirty-eight schools were contacted again in 2008, and were invited to participate once more in a similar survey. At that time, twenty-seven schools agreed to participate, and all sixth and seventh graders in these twenty-seven schools were invited to take part in the survey (cohort II, see Table 1). Pupils at these twenty-seven schools, from both 2001 and 2008 , constitute the study sample of the present study. The present study was conducted according to the guidelines laid down in the Declaration of Helsinki, and all procedures involving human subjects were approved by the Norwegian Social Science Data Services. Written informed consent was obtained from all subjects.

Initially, Hedmark and Telemark counties were chosen because the subscription programme was about to start in these two counties in the school year 2001/02. A baseline questionnaire survey was conducted in September 2001 (before the programme started). The 2008 survey was also conducted in September. In September 2001, none of the schools had any organised school fruit programme at the survey time. In September 2008, five schools participated in the free school fruit programme (schools with grades 1-10) (known as Free Fruit 08), while ten schools participated in the subscription programme (known as Subscription 08) and twelve schools did not participate in any official school fruit programme (known as No Programme 08). The free fruit programme was implemented from autumn 2007 in the five schools. We do not have data from the ten schools that participated in the subscription programme about when they entered the programme (between autumn 2001 and autumn 2008).

The questionnaire survey was completed by the pupils in the classroom in the presence of a trained project worker. One school lesson (45 min) was used to complete the questionnaire. A total of 1488 pupils (out of 1727 eligible; $86 \%$ ) in 2001 and 1339 pupils (out of 1712 eligible; 78\%) in 2008 completed the questionnaire and brought home a parent questionnaire to be completed by one of their parents. In the case of 1230 and 996 pupils, respectively, one of their parents completed the parent questionnaire. Descriptions of the samples in 2001 and 2008 are presented in Table 2 .

\section{Instrument}

A written 24-h FV recall was used to assess pupils' FV intake. The 24-h recall was read aloud to the pupils by a project worker. FV intake of the previous day was recorded for school days (i.e. the survey was conducted on weekdays, Tuesday to Friday). The 24-h recall separated the day into five time periods (before school, at school, after school, at dinner and after dinner). The pupils recalled the types of FV they ate at the different time periods in household measures (e.g. one apple and twelve grapes) or in portions (e.g. one portion of mixed green salad). The household measures were coded into portions/d, and one portion was set at about $80 \mathrm{~g}$ (ranging from $65 \mathrm{~g}$ (one carrot) to $105 \mathrm{~g}$ (one apple/one orange)). The conversions from household measures to portions were based on household measures and food weights published by the Norwegian National Association for 
Table 2. Description of the participants and the main variables at the 2001 and 2008 surveys

\begin{tabular}{lccc}
\hline & 2001 & 2008 & $P^{*}$ \\
\hline Number of schools & 27 & 27 & \\
Eligible pupils & 1727 & 1712 & \\
Pupil data & & & \\
$\quad$ Participating pupils & 1488 & 1339 & \\
Participation rate of pupils (\%) & 86 & 78 & \\
Sex of pupils (\% girls) & 50 & 52 & 0.21 \\
Age of pupils (\% seventh graders) & 47 & 49 & 0.50 \\
FV intake all day (portions/d) & 2.45 & 3.07 & $<0.001$ \\
FV intake at school (portions/d) & 0.36 & 0.71 & $<0.001$ \\
Eating FV 4-5 d/week at school (\%) & 29 & 59 & $<0.001$ \\
Parent data & & & \\
Participating parents & 1230 & 996 & \\
Participation rate of parents (\%) & 83 & 74 & \\
Sex of parents (\% women) & 85 & 78 & $<0.001$ \\
Age of parents (mean, years) & 39.9 & 41.1 & $<0.001$ \\
Edu of parents (\% with higher edu) & 42 & 54 & $<0.001$
\end{tabular}

FV, fruits and vegetables; edu, education.

* $P$ values are based on $t$ tests for continuous variables and on $\chi^{2}$ for dichotomous variables.

Nutrition and Health. Juices and potatoes were not included in the FV calculations. Fruits, vegetables and FV intake at school (portions/d), and fruits, vegetables and FV intake all day (portions/d) were calculated. The 24-h recall has been presented previously ${ }^{(18)}$, and validity and reliability have been reported for FV intake among sixth graders ${ }^{(18)}$.

In addition, a frequency question was included, asking: How often do you eat fruits and/or vegetables at school? Response alternatives were every school day, 4, 3, 2, 1 d/ week, less than once a week and never. The FFQ question was dichotomised into a new variable, eating FV at school 4 or $5 \mathrm{~d} /$ week $v$. less. Eating FV at school 4 or $5 \mathrm{~d} /$ week was interpreted as consuming FV at school on most school days. Based on data from a previous test-retest study involving 114 children from the sixth grade ${ }^{(18)}, 93 \%$ of the children were classified into the same category in the dichotomised variable ( 4 or $5 \mathrm{~d} /$ week $v$. less) on two assessments, $14 \mathrm{~d}$ apart (data not previously published).

The pupils reported their own sex. As an indicator of socioeconomic status, parents recorded their own level of education (lower: having no college or university education/higher: having attended college or university).

\section{Statistical analyses}

In the study sample, some pupils (fifty-eight in 2001 and thirty-seven in 2008) did not attend school the day before the survey day. Therefore, they were excluded from the analyses of intake at school, but they were included in all other analyses presented.

Describing the sample, differences between the 2001 and 2008 participants were analysed using $t$ test, for continuous variables and $\chi^{2}$ statistics for the categorical variables (Table 2). The main analyses conducted were multilevel mixed models with fruits, vegetables and FV at school and all day as separate outcome variables. All models included school as a random effect, and time (2001 v. 2008), group, sex and parental education level as fixed effects. A significant timex group interaction $(P \leq 0 \cdot 005)$, indicating different changes in FV intake over time for the different groups, was the test for the effect of the governmental efforts. In order to assess potential differences in the effect of the school fruit programmes for different groups (based on sex and parental education level), the third-order interactions time $x$ group $\times$ sex and time $\times$ group $\times$ parental education level were examined. An examination of the residuals did not reveal unacceptable departures from normality.

To conduct an attrition analysis, pupils at the twenty-seven schools in the study sample were compared with pupils at the eleven schools participated in 2001, but not in 2008, regarding sex, parental education level and FV intake at school and all day. For the analysis, $t$ test were used for continuous variables and $\chi^{2}$ statistics for the categorical variables. No significant differences between the study sample and pupils at schools that did not participate in 2008 were observed.

All analyses were conducted using SPSS 16 (SPSS Inc., Chicago, IL, USA).

\section{Results}

Unadjusted FV intake at school for the sixth and seventh-grade pupils at the twenty-seven schools increased from 0.36 to 0.71 portions/school day from 2001 to 2008 (Table 2). FV intake all day increased from 2.45 to 3.07 portions/d over the same period, and the proportion of pupils who reported eating FV at school 4 or $5 \mathrm{~d}$ /week increased from 29 to $59 \%$.

The increase in FV intake, both at school and all day, was largest within the schools that had been included since 2007 in the national free school fruit programme (Free Fruit 08), and was smallest within the schools that did not take part in any of the governmental efforts to increase FV intake at school (Table 3 ). The time $\times$ group interaction was significant for FV intake at school $(P=0.02)$, but was not significant for $\mathrm{FV}$ intake all day $(P=0 \cdot 20)$.

All effects appear to be due to an increase in fruit intake only. The time $\times$ group interactions for both fruit intake at school and fruit intake all day were significant, $P<0.001$ and $P=0.04$, respectively. The increases in fruit intake at school were $0.49,0.29$ and 0.18 portions/school day, respectively, for the Free Fruit 08, Subscription 08 and No Programme 08 schools, and the increases in fruit intake all day were $0.74,0.39$ and 0.16 portions/d, respectively (Table 3 ).

There were no significant differences in the change in vegetable intake between the groups from 2001 to 2008 , $P=0.31$ and 0.86 , respectively, for vegetables at school and vegetables all day.

No significant third-order interactions (time $\times$ group $\times$ sex or time $\times$ group $\times$ parental education level) were observed for any of the outcome variables, indicating that the effect of the governmental efforts was not significantly different for boys and girls or low and high parental education. To illustrate this, the proportion of pupils who reported eating $\mathrm{FV}$ at school $4-5 \mathrm{~d} /$ week in 2001 and 2008 , stratified on group (school fruit programmes in 2008) and sex/parental education level, is presented in Table 4.

\section{Discussion}

The results show an increase in pupils' intake of FV at school in Norway from 2001 to 2008 . Measured by a 24-h recall, the 
Table 3. Change in fruits and vegetables (FV) intake (portions/d) from 2001 to 2008 in relation to the different school fruit programmes

(Mean values and $95 \%$ confidence intervals)

\begin{tabular}{|c|c|c|c|c|c|}
\hline & \multicolumn{2}{|c|}{2001} & \multicolumn{2}{|c|}{2008} & \multirow{2}{*}{ Change 2001-08 } \\
\hline & Mean/d & $95 \% \mathrm{Cl}$ & Mean/d & $95 \% \mathrm{Cl}$ & \\
\hline \multicolumn{6}{|l|}{ At school } \\
\hline Free Fruit 08 & 0.34 & $0.17,0.51$ & 0.85 & $0.68,1.01$ & 0.51 \\
\hline Subscription 08 & 0.29 & $0.18,0.40$ & 0.68 & $0.57,0.79$ & 0.39 \\
\hline No Programme 08 & 0.46 & $0.35,0.56$ & 0.72 & $0.60,0.83$ & 0.26 \\
\hline \multicolumn{6}{|l|}{ Fruit (portions/d) } \\
\hline Free Fruit 08 & 0.22 & $0.10,0.33$ & 0.71 & $0.59,0.82$ & 0.49 \\
\hline Subscription 08 & 0.18 & $0.11,0.26$ & 0.47 & $0.39,0.55$ & 0.29 \\
\hline No Programme 08 & 0.31 & $0.23,0.38$ & 0.49 & $0.41,0.57$ & $0 \cdot 18$ \\
\hline \multicolumn{6}{|c|}{ Vegetables (portions/d) } \\
\hline Free Fruit 08 & 0.13 & $0.02,0.23$ & 0.14 & $0.03,0.25$ & 0.02 \\
\hline Subscription 08 & 0.11 & $0.04,0.18$ & $0 \cdot 21$ & $0.14,0.29$ & 0.10 \\
\hline No Programme 08 & $0 \cdot 15$ & $0.08,0.22$ & 0.23 & $0.15,0.30$ & 0.08 \\
\hline \multicolumn{6}{|l|}{ All day } \\
\hline \multicolumn{6}{|l|}{ FV (portions/d) } \\
\hline Free Fruit 08 & $2 \cdot 31$ & $1 \cdot 78,2 \cdot 85$ & $3 \cdot 18$ & $2.65,3.71$ & 0.87 \\
\hline Subscription 08 & $2 \cdot 25$ & $1 \cdot 90,2 \cdot 60$ & $2 \cdot 86$ & $2.50,3.22$ & 0.61 \\
\hline No Programme 08 & $2 \cdot 82$ & $2 \cdot 49,3 \cdot 16$ & $3 \cdot 15$ & $2.78,3.51$ & 0.32 \\
\hline \multicolumn{6}{|l|}{ Fruit (portions/d) } \\
\hline Free Fruit 08 & $1 \cdot 31$ & $0.96,1.66$ & 2.05 & $1 \cdot 70,2 \cdot 40$ & 0.74 \\
\hline Subscription 08 & 1.43 & $1 \cdot 20,1.67$ & 1.83 & $1.59,2.07$ & 0.39 \\
\hline No Programme 08 & $1 \cdot 77$ & $1.55,1.99$ & 1.93 & $1 \cdot 68,2 \cdot 18$ & 0.16 \\
\hline \multicolumn{6}{|c|}{ Vegetables (portions/d) } \\
\hline Free Fruit 08 & 1.00 & $0.72,1.29$ & $1 \cdot 14$ & $0.86,1.42$ & 0.13 \\
\hline Subscription 08 & 0.82 & $0.63,1.00$ & 1.03 & $0.85,1.22$ & 0.22 \\
\hline No Programme 08 & 1.05 & $0.88,1.23$ & $1 \cdot 22$ & $1.02,1.41$ & 0.16 \\
\hline
\end{tabular}

Free Fruit 08 , free school fruit programme; Subscription 08 , subscription programme; No Programme 08 , schools not participating in any official school fruit programme.

FV intake at school had doubled in these twenty-seven random schools from 0.36 portions/school day in 2001 to 0.71 portions/school day in 2008. The proportion of pupils reported eating FV at school 4 or $5 \mathrm{~d} /$ week had also doubled over the same period, from 29 to $59 \%$.
The effect is clearly largest in the schools that were enrolled in the free fruit programme from 2007 (all combined schools with grades from 1 to 10). Also, there appears to be a greater increase in FV intake in the schools that participated in the subscription programme in 2008 than in the schools that did

Table 4. Proportion of pupils reporting to be eating fruits and vegetables at school 4 or $5 \mathrm{~d} /$ week stratified on group (school fruit programmes in 2008) and sex/parental education level

(Percentages and 95\% confidence intervals)

\begin{tabular}{|c|c|c|c|c|c|}
\hline & \multicolumn{2}{|c|}{2001} & \multicolumn{2}{|c|}{2008} & \multirow{2}{*}{$\begin{array}{l}\text { Change } 2001-08 \\
\text { Percentage points }\end{array}$} \\
\hline & Percentage & $95 \% \mathrm{Cl}$ & Percentage & $95 \% \mathrm{Cl}$ & \\
\hline \multicolumn{6}{|l|}{ Free Fruit 08} \\
\hline Boys & 20 & 7,33 & 81 & 68,94 & 61 \\
\hline Girls & 38 & 24,51 & 88 & 75,100 & 50 \\
\hline Low parental edu & 28 & 15,40 & 79 & 66,92 & 52 \\
\hline High parental edu & 30 & 16,44 & 90 & 77,102 & 60 \\
\hline \multicolumn{6}{|l|}{ Subscription 08} \\
\hline Boys & 23 & 14,31 & 57 & 48,65 & 34 \\
\hline Girls & 32 & 23,40 & 68 & 60,77 & 37 \\
\hline Low parental edu & 25 & 16,33 & 59 & 50,68 & 35 \\
\hline High parental edu & 29 & 21,38 & 66 & 57,74 & 36 \\
\hline \multicolumn{6}{|l|}{ No Programme 08} \\
\hline Boys & 25 & 17,34 & 35 & 25,44 & 9 \\
\hline Girls & 45 & 37,53 & 47 & 39,56 & 3 \\
\hline Low parental edu & 35 & 27,42 & 34 & 25,43 & 0 \\
\hline High parental edu & 36 & 27,44 & 48 & 39,57 & 12 \\
\hline
\end{tabular}

Free Fruit 08 , free school fruit programme; edu, education; Subscription 08 , subscription programme; No Programme 08 , schools not participating in any official school fruit programme. 
not take part in any public programme. These results indicate that the subscription programme and the free school fruit programme have been effective.

Only a few similar non-academically initiated school FV interventions including free or subsidised FV have been evaluated, with the results being published in international scientific journals. In three independent studies, the National School Fruit Scheme in the UK, providing one piece of fruit or vegetable to school children on each school day, initiated and implemented by the UK Government, has been reported to increase school children's intake of fruits, respectively, with about $50 \mathrm{~g} / \mathrm{d}^{(19)}, 4.7$ pieces/week $^{(20)}$ and 0.5 portions/ $\mathrm{d}^{(21)}$. In the Netherlands, the Schoolgruiten project, initiated, developed and implemented by a public-private partnership of the Netherlands Nutrition Centre Foundation, providing school children with free fruit or vegetables twice a week, has been reported to increase elementary school children's fruit intake with $0 \cdot 15$ servings/ $\mathrm{d}^{(22)}$. The Norwegian subscription programme and a free pilot version have been reported to increase FV intake at school with 0.2 and 0.9 portions/d, respectively ${ }^{(6)}$. In the USA, the Fresh Fruit and Vegetable Snack Program, administered by the United States Department of Agriculture's Food and Nutrition Service, was initiated in 2002. Recently, an evaluation of this programme has been published showing that intervention school students, compared with control school students, were more likely to report eating fruit and drinking $100 \%$ fruit juice at least two times per day $(39.3 v .27 \cdot 3 \%)$ and consuming total fruit, juice and vegetables $(22 v .18 .4 \%)$ five or more times per day ${ }^{(23)}$. Pilot projects from Denmark ${ }^{(24)}$ (subscription programme initiated by the Danish Cancer Society) and New Zealand ${ }^{(25)}$ (free fruit pilot programme funded by the New Zealand Ministry of Health) have also been reported to increase fruit intake; both with an effect size of about 0.4 pieces/school day. Recently, the European Union has also decided upon initiating a school fruit programme from the school year 2009/10, and the European Commission is allocating $€ 90$ million per year for the provision of $\mathrm{FV}$ in European schools ${ }^{(26)}$.

All effects of the school fruit programmes in Norway appear to be on fruit intake, and there were no effects on vegetable intake, despite the fact that both the subscription and the free programmes are supposed to include both fruits and vegetables (carrots). Similar results are also reported from the British ${ }^{(19,21)}$, Dutch $^{(22)}$ US $^{(23)}$ and Danish ${ }^{(24)}$ studies. The FV recommendation in Norway is to eat at least two portions of fruit and three portions of vegetables per day. Table 3 shows that the average fruit intake in 2008 is about 2 portions/d, but that the vegetable intake is only about 1 portion/d. Increasing vegetable intake among children and adolescents remains a great challenge. Clearly, fruits are more practical in a school FV programme as they come in convenient portion sizes, in their own package and, compared with most vegetables, they need less preparation before being eaten ${ }^{(6)}$. Fruits are also more practical to eat than vegetables in between meals. With the Norwegian tradition of having only one hot meal per day, vegetables are mostly eaten for dinner. The likeliness of Norwegians eating large amounts of vegetables with other meals is low. In a recent study, only $40 \%$ of adolescents reported to have eaten vegetables at dinner the day before the survey day ${ }^{(27)}$.
Due to the rather large socio-economic status and sex disparities in health in Norway ${ }^{(12,15)}$, and similar disparities in eating behaviours such as FV intake ${ }^{(13,14)}$, it is of utmost importance that the efforts to increase FV intake are also effective among those who need it the most, e.g. boys and children of parents without higher education. However, no significant third-order interactions were observed in the present study, and the group effect (effect of the school fruit programmes) appears to be similar for both boys and girls and for children of parents both with and without higher education. Table 4 shows that the school fruit programmes clearly have an effect for both boys and children of parents without higher education. The percentage of boys and children of parents without higher education who reported eating FV at school 4 or $5 \mathrm{~d} /$ week within the Free Fruit 08 schools increased from 20 and $28 \%$ in 2001 to 81 and $79 \%$ in 2008, respectively.

An important issue regarding potential health effects of school fruit schemes is whether they cause lasting effects, i.e. an increased FV intake is sustained also after the children stop receiving free fruit. Evaluations of the UK school fruit scheme do report no significant effect when the pupils were no longer eligible to receive free $\mathrm{FV}^{(19-21)}$. A pilot version of the Norwegian free school fruit programme (1 year of free school fruit) has, however, on the contrary reported that an increased FV intake is sustained 3 years after the end of the intervention ${ }^{(8)}$. A Norwegian cost-benefit analysis reported that an increase of $2.5 \mathrm{~g} / \mathrm{d}$ is needed in order for the Norwegian School Fruit Programme to be cost effective, if offered for free for all 10 years of elementary and secondary school $^{(28)}$. However, an assumption is that the increased FV intake has to be sustained throughout life.

A limitation of the study is the non-randomisation of the different groups. The Free Fruit 08 groups constitute all combined schools (with grades 1-10), and the subscription schools are self-selected. The pupils at the different schools may be different, and as can be seen from Tables 3 and 4, there are differences in FV intake at school between the Free Fruit 08, Subscription 08 and No Programme 08 schools in 2001, before the school fruit programmes were initiated. However, the trends and results reported in the present study are clear, and a potential group effect is expected to be small. A second limitation of the study is that some schools now organise their own school fruit programmes. School fruit has been a hot topic in Norway over the last few years, maybe due to the long-term sustained public efforts. Within the No Programme 08 group, one of the schools had its own free fruit programme, and therefore the results presented in the present study may be underestimated.

The strengths of the present study are that it includes repeated data from a large number of randomly selected schools, and that it includes an evaluation of the public efforts to increase FV intake at school in a natural setting.

\section{Conclusion}

There has been a large increase in pupils eating fruit at school from 2001 to 2008 in Norway, and the school fruit programmes seem to have been effective. However, a great challenge remains in increasing vegetable intake. 


\section{Acknowledgements}

The present work was supported by the Norwegian Research Council (both 2001 and 2008 studies). Since 2006, K.-I. K. has been employed by the Norwegian Directorate of Health which is responsible for the implementation of the school fruit programmes. The author contributions are as follows: K.-I. K. conceived the 2001 study. E. B. conceived the 2008 study. E. B. and M. H. designed the present study. E. B. analysed the data and all authors contributed to the interpretation. E. B. drafted the manuscript, and M. H. and K.-I. K. revised it critically. All authors have approved the final version of the manuscript.

\section{References}

1. World Health Organization (2003) Diet, Nutrition and the Prevention of Chronic Diseases. Joint WHO/FAO Expert Consultation. Technical Report Series no. 916. Geneva: WHO.

2. World Health Organization (2004) Global Strategy on Diet, Physical Activity and Health. Geneva: WHO.

3. Øverby NC \& Andersen LF (2002) Ungkost-2000: Landsomfattende kostholdsunders $\phi$ kelse blant elever i 4. og 8. klasse i Norge (Ungkost-2000: Nationwide Nutrition Survey Among Students in classes 4 and 8 in Norway). Oslo: Sosial- og helsedirektoratet.

4. Kelder SH, Perry CL, Klepp K-I, et al. (1994) Longitudinal tracking of adolescent smoking, physical-activity, and food choice behaviours. Am J Public Health 84, 1121-1126.

5. Lien N, Lytle LA \& Klepp K-I (2001) Stability in consumption of fruit, vegetables, and sugary foods in a cohort from age 14 to age 21. Prev Med 33, 217-226.

6. Bere E, Veierød MB \& Klepp K-I (2005) The Norwegian School Fruit Program: evaluating paid vs. no-cost subscriptions. Prev Med 41, 463-470.

7. Bere E, Veierød MB, Bjelland M, et al. (2006) Free school fruit - sustained effect 1 year later. Health Educ Res 21, 268-275.

8. Bere E, Veierød MB, Skare $\varnothing$, et al. (2007) Free school fruit sustained effect three years later. Int J Behav Nutr Phys Act 4, 5.

9. Bere E \& Klepp K-I (2006) Free vs. paid school fruit program big difference with respect to social inequality. In Ethics and the Politics of Food. Preprints of the 6th Congress of the European Society for Agricultural and Food Ethics, 22-24 June, 2006, pp. 353-357 [M Kaiser and M Lien, editors]. Wageningen: Wageningen Academic Publishers.

10. Jaime PC \& Lock K (2009) Do school based food and nutrition policies improve diet and reduce obesity? Prev Med 48, 45-53.

11. de Sa J \& Lock K (2008) Will European agricultural policy for school fruit and vegetables improve public health? A review of school fruit and vegetable programmes. Eur J Public Health 18, $558-568$

12. Sosial- og helsedirektoratet (2005) Sosial- og helsedirektoratets handlingsplan mot sosiale ulikheter $i$ helse: Gradientutfordringen (Social and Health Directorate's Action Plan on Social Inequalities in Health: Gradientutfordringen). Oslo: Sosial- og helsedirektoratet.
13. Bere E, Brug J \& Klepp K-I (2008) Why do boys eat less fruit and vegetables than girls? Public Health Nutr 11, 321-325.

14. Bere E, van Lenthe F, Klepp K-I, et al. (2008) Why do parents' education level and income affect the amount of fruits and vegetables adolescents eat? Eur J Public Health 18, $611-615$.

15. Det kongelige helse- og omsorgsdepartementet (2007) St.meld nr. 20 (2006-2007): Nasjonal strategi for å utjevne sosiale helseforskjeller (White Paper No. 20 (2006-2007): National Strategy to Equalize Social Health Differences). Oslo: Det kongelige helse- og omsorgsdepartementet.

16. Det kongelige kunnskapsdepartement (2008) Ot.prp. nr. 40 (2007-2008): Om lov om endringar $i$ opplaringslova og privatskolelova (Proposition. No. 40 (2007-2008): The Law on Changes in the Education Act and Private Law). Oslo: Det kongelige kunnskapsdepartement.

17. Bere E, Veierod MB, Bjelland M, et al. (2006) Outcome and process evaluation of a Norwegian school-randomized fruit and vegetable intervention: fruits and vegetables make the marks (FVMM). Health Educ Res 21, 258-267.

18. Andersen LF, Bere E, Kolbjørnsen N, et al. (2004) Validity and reproducibility of self-reported intake of fruit and vegetable among 6th graders. Eur J Clin Nutr 58, 771-777.

19. Wells L \& Nelson M (2005) The national school fruit scheme produces short-term but not longer-term increases in fruit consumption in primary school children. Br J Nutr 93, 537-542.

20. Fogarty AW, Antoniak M, Venn AJ, et al. (2007) Does participation in a population-based dietary intervention scheme have a lasting impact on fruit intake in young children? Int J Epidemiol 36, $1080-1085$.

21. Ransley JK, Greenwood DC, Cade JE, et al. (2007) Does the school fruit and vegetable scheme improve children's diet? A non-randomised controlled trial. $J$ Epidemiol Commun Health 61, 699-703.

22. Tak NI, Te Velde SJ \& Brug J (2008) Long-term effects of the Dutch schoolgruiten project - promoting fruit and vegetable consumption among primary-school children. Public Health Nutr 22, 1-11.

23. Davis EM, Cullen CW, Watson KB, et al. (2009) A fresh fruit and vegetable program improves high school students' consumption of fresh produce. J Am Diet Assoc 109, 1227-1231.

24. Eriksen K, Haraldsdottir J, Pederson R, et al. (2003) Effect of a fruit and vegetable subscription in Danish schools. Public Health Nutr 6, 57-63.

25. Ashfield-Watt PAL, Stewart EA \& Scheffer JA (2009) A pilot study of the effect of providing daily free fruit to primaryschool children in Auckland, New Zealand. Public Health Nutr 12, 693-701.

26. European Commission. http://ec.europa.eu/agriculture/markets/ fruitveg/sfs/ (accessed July 2009).

27. Vejrup K, Lien N, Klepp K-I, et al. (2008) Consumption of vegetables at dinner in a cohort of Norwegian adolescents. Appetite 51, 90-96.

28. Sælensminde K (2006) Frukt og grønnsaker i skolen. Beregning $a v$ samfunnsøkonomisk lonnsomhet (Fruit and Vegetables in School. Calculation of the Economic Profitability). Oslo: Sosial- og helsedirektoratet. 
PAPER III

Changes in 10-12 year old's fruit and vegetable intake in Norway from 2001 to 2008 in relation to gender and socioeconomic status - a comparison of two cross-sectional groups 



\title{
Changes in 10-12 year old's fruit and vegetable intake in Norway from 2001 to 2008 in relation to gender and socioeconomic status - a comparison of two cross-sectional groups
}

\author{
Marit Hilsen ${ }^{1,2^{*}}$, Maartje M van Stralen ${ }^{3}$, Knut-Inge Klepp ${ }^{2}$ and Elling Bere ${ }^{1}$
}

\begin{abstract}
Background: Norwegian children and adolescents eat less than half of the recommended 5 portions of fruit and vegetables (FV) per day. Gender and socioeconomic disparities in FV consumption shows that boys and children of lower socioeconomic status (SES) eat less FV than girls and high SES children. We also know that accessibility and preferences has been identified as two important determinants of FV intake. The objectives of this study were to compare FV intake among Norwegian $6^{\text {th }}$ and $7^{\text {th }}$ graders in 2001 and 2008, to explore potential mediated effects of accessibility and preferences on changes in FV over time, to explore whether these changes in FV intake was moderated by gender and/or SES and whether a moderated effect in FV intake was mediated by accessibility and preferences of $\mathrm{FV}$.
\end{abstract}

Methods: The baseline survey of the Fruits and Vegetables Make the Marks project was conducted in 2001 at 38 randomly chosen schools in two Norwegian counties. A second survey was conducted at the same schools in 2008. A total of 27 schools participated in both surveys $(2001 n=1488,2008 n=1339)$. FV intake was measured by four food frequency questions (times/week) in a questionnaire which the pupils completed at school. SES was based on parents' reports of their own educational level in a separate questionnaire. The main analyses were multilevel linear regression analyses.

Results: A significant year*parental educational level interaction was observed $(p=0.01)$. FV intake decreased among pupils of parents with lower educational level (13.9 vs. 12.6 times/week in 2001 and 2008, respectively), but increased among pupils of parents with higher education (14.8 vs. 15.0 times/week, respectively). This increasing SES disparity in FV intake was partly mediated by an increasing SES disparity in accessibility and preferences over time, wherein children with higher educated parents had a steeper increase in accessibility and preferences over time than children with lower educated parents. The year*sex interaction was not significant ( $p=0.54)$.

Conclusions: This study shows an increase in SES disparities in $6^{\text {th }}$ and $7^{\text {th }}$ graders FV intake from 2001 to 2008, partly mediated by an increasing SES disparity in accessibility and preferences of FV.

Keywords: Fruit and vegetable intake, time trends, gender, socioeconomic status, children

\section{Background}

Research shows that a diet high in fruits and vegetables (FV) reduces the risk of developing several chronic diseases [1] and that food habits and preferences established during childhood and adolescents track well into

\footnotetext{
* Correspondence: marithilsen@medisin.uio.no

${ }^{1}$ Faculty of Health and Sport, University of Agder, Norway

Full list of author information is available at the end of the article
}

adulthood [2,3]. Childhood is therefore a crucial time point to initiate lifelong healthy eating habits and thereby achieve a maximum preventive effect against diet related chronic diseases. However, data shows that less than $50 \%$ of Norwegian $8^{\text {th }}$ graders consume the recommended intake of FV per day. Only $11 \%$ of the $8^{\text {th }}$ graders consumed more than 500 grams FV per day and 
the mean FV intake among $8^{\text {th }}$ graders was 255 grams per day $[4,5]$.

Norway is a welfare state with a high gross domestic product (GDP) per capita. However, social disparities, including health behaviour and outcome, is evident in Norway [6]. E.g. food choices have been reported to follow a socioeconomic gradient indicating that groups of higher socioeconomic status (SES) consume healthy food items more frequently than individuals of lower SES [7]. These gradients have also been observed among children and adolescents $[4,8,9]$. In addition to social disparities in food choices, gender differences have also been observed indicating that girls report to eat more FV than boys [9].

Beyond socioeconomic and gender differences the aetiology of food behaviour may be further understood by studying determinants of FV intake. Modifiable determinants such as accessibility and preferences have, in addition to being correlated $(r=0.43$ and $r=0.45$, respectively) to FV intake [10], also been reported to be among the strongest predictors to explain future FV intake among schoolchildren [11]. Previous longitudinal analysis within the Fruits and Vegetables Make the Marks (FVMM) cohort project showed that perceived accessibility alone explained 90\% (age 12.5) and 50\% (age 15.5) of parental educational disparities [8], and preferences alone explained $81 \%$ of the gender disparities [12] observed in FV intake among adolescents.

The Norwegian government has aimed at reducing the social disparities in health behaviour and outcome by several initiatives [13] including nutritional guidelines $[14,15]$. Due to these governmental efforts it is of great interest to study the most recent development in health related trends. Data on the development of gender and socioeconomic disparities in eating habits over the last years is scarce and the need for such results are therefore called for in order to tailor effective interventions in the future.

The objectives of this study were to compare FV intake among Norwegian $6^{\text {th }}$ and $7^{\text {th }}$ graders in 2001 and 2008, to explore potential mediated effects of accessibility and preferences on changes in FV over time, to explore whether these changes in FV intake was moderated by gender and/or SES and whether this moderating effect on changes in FV intake over time was mediated by accessibility and preferences of FV.

\section{Methods}

\section{Design and study sample}

In 2001, 48 schools from Hedmark and Telemark counties (24 schools in each county) were randomly selected and invited to participate in the FVMM research project (cohort I), and 19 schools from each county agreed to participate. All $6^{\text {th }}$ and $7^{\text {th }}$ graders (age 10-12) in these
38 schools were invited to take part in a questionnaire survey (which was the baseline survey for the FVMM intervention project) [16-18]. These 38 schools were recontacted in 2008 and invited to once more participate in a similar survey among $6^{\text {th }}$ and $7^{\text {th }}$ graders (cohort II). At that time 27 schools agreed to participate, and all $6^{\text {th }}$ and $7^{\text {th }}$ graders in these 27 schools were invited to take part in the survey. The study sample of these two repeated cross-sectional studies includes $6^{\text {th }}$ and $7^{\text {th }}$ graders from both 2001 and 2008 at these 27 schools. Both studies were conducted in the September month. During this period there has been some changes in FV availability at some of the schools. A subscription program was implemented nation-wide in 2003, and all elementary schools are eligible to participate. This subscription program offers subscribing pupils one fruit or vegetable per day at schools taking part in the program. The cost of the subscription, covered by the parents, was $2.50 \mathrm{NOK}$ per day (approximately €0.30). From autumn 2007, an official free school fruit program (without parental payment) was implemented in all secondary elementary schools (grades 8-10) and all combined schools (grades 1-10). Therefore, in 2001 none of the schools included in this study had any organized FV program, but in 2008, only 5 schools had a free FV program, 10 schools had a FV subscription program and 12 schools had no FV program. These nation-wide school fruit scheme has recently been evaluated within the FVMM project [19]. Research clearance was obtained from The Norwegian Social Science Data Services.

\section{Instrument}

A questionnaire was completed by the pupils in the classroom in the presence of a trained project worker. One school-lesson (45 minutes) was used to complete the questionnaire. The FV intake among the pupils was assessed by the following four frequency questions; how often do you eat 1 ) vegetables for dinner, 2) other vegetables (e.g., carrot for school lunch), 3) apples, oranges, pears or bananas, 4) other fruits or berries. The response categories for all four questions had 10 alternatives ranging from 'never' $=0$ to 'several times a day' $=10$, giving a scale ranging from 0 to 40 times per week. In a sample of $1146^{\text {th }}$ grade pupils, the test-retest correlation of this scale was 0.75 [20]. The correlation between the scale and a validation method (7 day food diary) was 0.32 in a separate validation study of $856^{\text {th }}$ grade pupils, a correlation which is similar to what have been found in other studies among the same age group [20].

The potential determinants, accessibility and preferences, were assessed by respectively five and four statements in the questionnaire with response alternatives ranging from 'I fully disagree' (value $=-2$ ) to 'I fully agree' (value $=2$ ). The scores of these questions were summed. 
Preference had a possible range from -8 to 8 and was assessed by the following statements: 'Fruits and vegetables make my meals taste better', 'I really like raw vegetables', 'Fruits are among the best (foods) I know' and 'Fruits and vegetables are very suitable as snacks'. Perceived accessibility at home had a possible range from -10 to 10 and was assessed by: 'At home we usually have fruits and vegetables in the refrigirator', 'At home I am allowed to eat fruits and vegetables whenever I want', 'Mother or father do sometimes cut fruits and vegetables for me as a snack', "At home we usually have vegetables for dinner every day" and 'At home we usually have fruits available in a (fruit-) bowl'. These scales have been analysed for reliability, with testretest correlations of 0.66 (accessibility) and 0.74 (preference) [21].

The pupils reported their own gender. After completing the questionnaire the pupils received a parent questionnaire to bring home to their parents for one of the parents to complete. The parents educational level was assessed individually by the parent answering the question: "What level of education do you have?". The question had four response alternatives: 'elementary school', 'high school', 'college or university (3 years or less)', and 'college or university (more than 3 years)'. This variable was dichotomized (lower: having no college or university education/higher: having attended college or university). The majority of those who completed the parental questionnaire were mothers $(81.9 \%)$.

\section{Statistical analyses}

Descriptive analyses were conducted by using one-way ANOVA in SPSS 14 (Table 1 and 2). The main analyses conducted were multilevel linear regression analyses using MLWin (version 2.02). We defined two levels in our multilevel analyses (1) student and (2) school. All models included time (2001 vs. 2008), gender, parental education and also whether the school participated in any school fruit program, as independent variables or covariates. First we calculated the total effect of time on FV intake (c-coefficient) (Figure 1). Second, the mediated effect of accessibility and preferences of the changes in FV intake over time were examined by using the products of coefficient method [22]. In this method, first the effect of time on the theoretical mediators accessibility and preferences is calculated (a-coefficient), followed by the calculation of the association of the theoretical mediators (i.e. accessibility and preferences) on FV intake after controlling for time (b-coefficient). The mediated effect is the product of the $a-$ and $b$ coefficient ( $a * b)$ and provides an estimate of the relative strength of the mediation effect. The Sobel test was used to assess the statistical significance of a mediating effect by dividing the products-of coefficients $(a * b)$ by its standard error $\mathrm{SE}_{\mathrm{ab}}=\sqrt{ }\left(\left(\mathrm{a}^{2 *} \mathrm{SE}_{\mathrm{b}}{ }^{2}\right)+\left(\mathrm{b}^{2 *} \mathrm{SE}_{\mathrm{a}}{ }^{2}\right)\right)$. Third, in order to examine whether the trend in FV intake was different for different SES or gender groups (see Figure 1), we tested the moderated effect of parental education and gender on the changes in FV intake over time, by including two interaction terms ((1) time* parental_education and (2) time*gender)) into the first regression analyses ( $\mathrm{c}_{\mathrm{mod}^{-}}$-coefficient). A significant interaction term would indicate different changes in FV intake over time for the different subgroups. Fourth, in order to investigate the underlying reason for a possible interaction

Table 1 Characteristics of the study population, FV intake and determinants of FV intake in the 2001 and 2008 survey

\begin{tabular}{|c|c|c|c|c|}
\hline & \multicolumn{2}{|c|}{2001} & \multicolumn{2}{|c|}{2008} \\
\hline & $\mathrm{n}$ & Mean $(95 \% \mathrm{Cl})$ & $\mathrm{n}$ & Mean $(95 \% \mathrm{Cl})$ \\
\hline Schools & 27 & & 27 & \\
\hline Pupils & 1488 & & 1339 & \\
\hline \multicolumn{5}{|l|}{ Gender } \\
\hline Boys & $748(50.3 \%)$ & & $630(47.9 \%)$ & \\
\hline Girls & $738(49.7 \%)$ & & $684(52.1 \%)$ & \\
\hline \multicolumn{5}{|l|}{ Grade } \\
\hline 6th & $782(52.6 \%)$ & & $686(51.3 \%)$ & \\
\hline 7th & $706(47.4 \%)$ & & $652(48.7 \%)$ & \\
\hline Parents & 1230 & & 996 & \\
\hline \multicolumn{5}{|l|}{ Parental educational level } \\
\hline EDU high & $511(42.2 \%)$ & & $527(53.6 \%)$ & \\
\hline EDU low & $699(57.8 \%)$ & & $457(46.4 \%)$ & \\
\hline \multicolumn{5}{|l|}{ Intake and determinants } \\
\hline FV intake & 1442 & $14.2(13.8-14.6)$ & 1263 & $13.9(13.5-14.2)$ \\
\hline Accessibility & 1487 & $4.0(3.8-4.2)$ & 1333 & $5.1(4.9-5.3)$ \\
\hline Preferences & 1480 & $2.7(2.5-2.9)$ & 1320 & $3.1(2.9-3.2)$ \\
\hline
\end{tabular}

$\mathrm{Cl}$, confidence interval. $\mathrm{FV}$ intake, fruit and vegetable intake. EDU high, higher parental education. EDU low, lower parental education 
Table 2 Comparisons of the 2001 and 2008 cohorts on the four separate FFQ items

\begin{tabular}{|c|c|c|c|c|}
\hline Question & n & Mean & Standard Deviation & p-value* \\
\hline \multicolumn{5}{|c|}{ How often do you eat vegetables for dinner? } \\
\hline 2001 & 1476 & 3.8 & 2.2 & \\
\hline 2008 & 1321 & 3.9 & 2.1 & 0.439 \\
\hline \multicolumn{5}{|c|}{ How often do you eat other vegetables? } \\
\hline 2001 & 1462 & 2.8 & 2.5 & \\
\hline 2008 & 1292 & 2.5 & 2.3 & 0.003 \\
\hline \multicolumn{5}{|c|}{ How often do you eat apples, oranges, pears or bananas? } \\
\hline 2001 & 1470 & 4.6 & 2.7 & \\
\hline 2008 & 1317 & 4.9 & 2.5 & 0.009 \\
\hline \multicolumn{5}{|c|}{ How often do you eat other fruits and berries? } \\
\hline 2001 & 1466 & 3.0 & 2.5 & \\
\hline 2008 & 1294 & 2.7 & 2.2 & $<0.001$ \\
\hline
\end{tabular}

* One-Way ANOVA

with SES or gender, a test of mediation of a moderating effect was conducted where it is assumed that the interaction predicts a mediator which predicts the outcome [23]. In other words, we examined whether a possible SES or gender disparity in changes in FV intake over time could be explained by a SES or gender disparity in changes in the potential mediators over time (see Figure 2 and 3). First we calculated the effect of the interaction terms (i.e. time*education_parents and time* gender) on the theoretical mediators (i.e. accessibility and prefer-

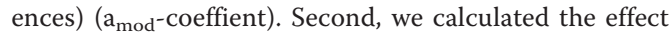
of the theoretical mediators on FV intake when adjusted for the interaction terms between the moderator and independent variable (i.e. time*education_parents and time*gender) and the interaction terms between the moderator and the mediator variable (i.e. accesibility*parental_education and accessibility*gender or preference ${ }^{*}$ parental_education and preference*gender) $\left(b_{\text {mod }^{-}}\right.$ coefficient). The mediation of a moderation effect can be estimated by the product-of-coefficient test ( $a_{\text {mod }}{ }^{*} b$ mod) and its significance can be estimated by dividing it by its standard error $\left(\mathrm{SEa}_{\bmod } \mathrm{b}_{\bmod }=\sqrt{ }\left(\left(\mathrm{a}_{\bmod }{ }^{2 *} \mathrm{SEb}_{\bmod }{ }^{2}\right)\right.\right.$ $\left.+\left(\mathrm{b}_{\mathrm{mod}}{ }^{2 *} \mathrm{SEa}_{\text {mod }}{ }^{2}\right)\right)$. An examination of the residuals did not reveal unacceptable departures from normality. Since interaction terms have less power, $\mathrm{p}$ values, as an indicator of the significance, of interaction terms are

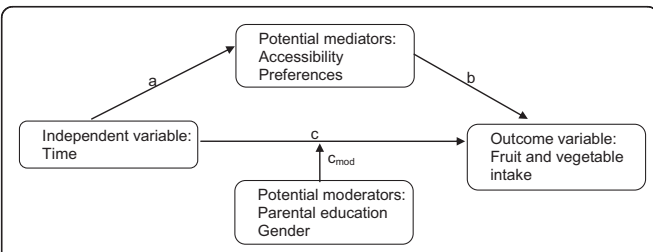

Figure 1 Model of mediation and moderation of changes in FV intake over time. recommended to be set at 0.10 [24]. All analyses in the current paper have been adjusted for whether the pupils were in schools participating in the fruit program or not. Attrition analysis were conducted, comparing the pupils at the 27 schools included in the study sample with the pupils at the 11 schools participating in 2001 but not in 2008, regarding gender, parental education, FV intake, accessibility and preferences. For the analysis $\mathrm{t}$-tests were used for continous variables and $\chi^{2}$ statistics were used (categorical data). No significant differences between the study sample and pupils at schools that did not participate in 2008 were found.

\section{Results}

A total of 1488 pupils (out of 1727 eligible; 86\%) in 2001 and 1339 pupils (out of 1712 eligible; 78\%) in 2008 completed the questionnaire and brought home a parent questionnaire to be completed by one of their parents. For respectively 1230 and 996 pupils, one of their parents completed the parent questionnaire. Descriptions of the samples in 2001 and 2008 are presented in Table 1.

\section{Changes in FV intake, accessibility and preferences over time}

Table 1 shows the changes in FV intake, accesibility and preferences of FV over time. A decrease in FV intake from 14.2 to 13.9 times/week among $6^{\text {th }}$ and $7^{\text {th }}$ graders

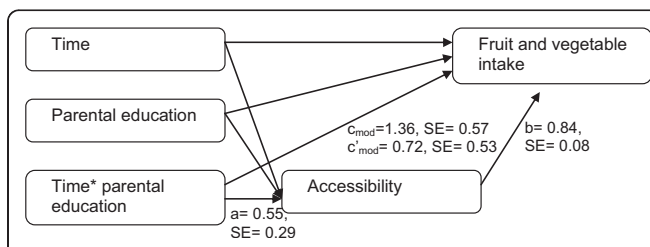

Figure 2 Model of mediation of accessibility on moderated effect of SES on changes in FV intake. 


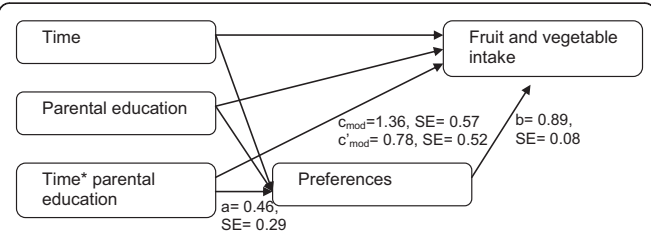

Figure 3 Model of mediation of preferences on moderated effect of SES on changes in FV intake.

at the 27 schools was observed from 2001 to 2008 ( $\mathrm{c}=$ $-0.55, \mathrm{SE}=0.29, \mathrm{p}=0.06)$. At the same time mean scores in both accessibility and preferences significantly increased from 4.0 to $5.1(\mathrm{a}=1.08, \mathrm{SE}=0.15, \mathrm{p}<$ $0.001)$ and from 2.7 to $3.1(\mathrm{a}=0.31, \mathrm{SE}=0.15, \mathrm{p}<$ 0.05), respectively. Analyzing the four items in the FV scale separately, the consumption of 'vegetables for dinner' (3.8 vs. 3.9 times/week, p = 0.44) and 'apples, oranges, pears and bananas' ( 4.6 vs. $4.9, \mathrm{p}=0.009$ ) increased, while the intake of 'other vegetables' ( 2.8 vs. $2.5, \mathrm{p}=0.003)$ and 'other fruits and berries' (3.0 vs. 2.7, $\mathrm{p}<0.001$ ) decreased from 2001 to 2008 (Table 2).

\section{Mediated effect of accessibility and preferences on changes in FV intake over time}

Mediation analyses showed that both changes in accessibility $(\mathrm{ab}=0.89, \mathrm{SE}=0.13, \mathrm{p}<0.001)$ and changes in preferences $(\mathrm{ab}=0.25, \mathrm{SE}=0.12, \mathrm{p}<0.05)$ suppressed the changes in FV intake over time (Table 3). Suppressor effects, also called inconsistent mediated effects, are mediated effects with a different sign than the direct effect in a model. This inconsistent mediator suppresses the total effect. In other words, the decrease in FV intake over time would have been higher if the accessibility and preference of FV had not increased.

\section{Moderated effect of parental education and gender on changes in FV intake over time}

During this time period the proportion of parents with higher education increased from $42.2 \%$ to $53.6 \%$ (Table 1). The multilevel linear regression analysis on FV intake showed a significant interaction between parental education level and time $\left(\mathrm{c}_{\bmod }=1.36, \mathrm{SE}=0.57, \mathrm{p}=0.01\right)$
(Figure 2 and 3). Subgroup analyses showed that FV intake decreased among pupils of parents with a low education from 13.9 times/week in 2001 to 12.6 times/ week in 2008 ( $\mathrm{c}=-2.72, \mathrm{SE}=0.73, \mathrm{p}<0.001)$, and slightly increased among pupils of parents with higher education from 14.8 times/week in 2001 to 15.0 times/ week in 2008 ( $\mathrm{c}=1.08, \mathrm{SE}=0.77, \mathrm{p}=0.16)$. These results indicate that SES disparity of FV intake increased over time in which lower SES children had a higher decrease in FV intake over time compare to a more stable intake among higher SES children. No significant interaction between time and gender was found $\left(\mathrm{c}_{\bmod }=\right.$ $0.31, \mathrm{SE}=0.57, \mathrm{p}=0.59$ ).

\section{Mediation of a moderated effect of parental education and gender on changes in FV intake}

Parental education moderated the changes in accessibility $\left(\mathrm{a}_{\text {mod }}=0.55, \mathrm{SE}=0.29, \mathrm{p}=0.06\right)$ (Figure 2$)$ and preferences $\left(\mathrm{a}_{\mathrm{mod}}=0.46, \mathrm{SE}=0.29, \mathrm{p}=0.11\right)$ (Figure 3 ) over time (Table 4). Subgroup analyses showed that children with high educated parents had a steeper increase in accessibility $\left(\mathrm{a}_{\bmod }=1.17, \mathrm{SE}=0.38, \mathrm{p}<\right.$ $0.00)$ and preferences $\left(\mathrm{a}_{\text {mod }}=0.14, \mathrm{SE}=0.38, \mathrm{p}=0.70\right)$ than children with low educated parents $\left(\mathrm{a}_{\bmod }=0.82\right.$, $\left.\mathrm{SE}=0.40, \mathrm{p}<0.05 ; \mathrm{a}_{\text {mod }}=0.05, \mathrm{SE}=0.39, \mathrm{p}=0.90\right)$. These results indicate that SES disparity in FV accessibility and preferences increased over time in which higher SES children had a higher increase in accessibility and preferences than lower SES children. Both accessibility $\left(\mathrm{b}_{\mathrm{mod}}=0.84, \mathrm{SE}=0.08, \mathrm{p}<0.001\right)$ and preferences $\left(b_{\text {mod }}=0.89, \mathrm{SE}=0.08, \mathrm{p}<0.001\right)$ were significantly independent associated with FV intake when adjusted for the independent variables and interaction term between time and parental education. A mediating effect of accessibility $\left(\mathrm{ab}_{\mathrm{mod}}=0.46, \mathrm{SE}_{\mathrm{mod}}=0.24, \mathrm{p}=0.05\right)$ and preferences $\left(\mathrm{ab}_{\mathrm{mod}}=0.41, \mathrm{SE}_{\mathrm{mod}}=0.26, \mathrm{p}=0.11\right)$ on the moderating effect of SES on FV intake was found (Table 4). This indicates that the increasing SES disparity in changes in FV intake over time could partly be explained by an increasing SES disparity in accessibility and preferences of FV over time. No significant mediation of accessibility $\left(\mathrm{ab}_{\mathrm{mod}}=0.05, \mathrm{SE}=0.25, \mathrm{p}=0.84\right)$ and preferences $\left(\mathrm{ab}_{\bmod }=0.22, \mathrm{SE}=0.26, \mathrm{p}=0.39\right)$ was found on the moderating effect of gender on changes in FV intake over time.

Table 3 Trend in FV intake and the mediated effect of preferences and accessibility on this trend

\begin{tabular}{lccccc}
\hline & $\mathbf{c}(\mathrm{SE})$ & $\mathbf{c}^{\prime}(\mathrm{SE})$ & $\mathrm{a}(\mathrm{SE})$ & $\mathbf{b}(\mathrm{SE})$ & $\mathbf{a b}(\mathrm{SE})$ \\
\hline FV intake & $-0.55(0.29) \neq$ & & & & \\
Accessibility & & $1.42(0.26)^{* * *}$ & $1.08(0.15)^{* * *}$ & $0.82(0.04)^{* * *}$ & $0.89(0.13)^{* * *}$ \\
Preferences & & $0.83(0.26)^{* *}$ & $0.31(0.15)^{*}$ & $0.83(0.04)^{* * *}$ & $0.25(0.12)^{*}$ \\
\hline
\end{tabular}

$\mathrm{c}=$ total change in FV intake over time; $\mathrm{c}^{\prime}=$ change in FV intake over time when adjusted for changes in the mediator; $\mathrm{a}=$ change in mediator over time; $\mathrm{b}=$ association between mediator and FV intake when adjusted for changes over time; $a b=$ mediated effect using the product of coefficient test. SE, standard error. All analyses are adjusted for clustering effects and time, gender, parental education and treatment condition. $\neq p<0.10 ;{ }^{*} p<0.05 ;{ }^{* *} p<0.01 ;{ }^{* * *} p<0.001$ 
Table 4 Mediated effect of accessibility and preferences on moderated effect of SES on FV intake trend

\begin{tabular}{lccccc}
\hline & $\mathbf{c}_{\text {mod }}(\mathrm{SE})$ & $\mathbf{c}_{\text {mod }}^{\prime}(\mathrm{SE})$ & $\mathbf{a}_{\text {mod }}(\mathrm{SE})$ & $\mathbf{b}_{\text {mod }}(\mathrm{SE})$ & $\mathbf{a b}_{\text {mod }}(\mathrm{SE})$ \\
\hline FV intake & $1.36(0.57)$ & & & & \\
Accessibility & & $0.72(0.53)$ & $0.55(0.29) \neq$ & $0.84(0.08)^{* * *}$ & $0.46(0.24) \neq$ \\
Preferences & & $0.78(0.52)$ & $0.46(0.29)$ & $0.89(0.08)^{* * *}$ & $0.41(0.26)$ \\
\hline
\end{tabular}

the interaction term (time* parental education) is the independent variable.

$c_{\text {mod }}=$ effect of parental education on the changes in FV intake over time; $\mathrm{C}_{\text {mod }}^{\prime}=$ effect of parental education on the changes in FV intake over time adjusted for changes in the mediator; $\mathrm{a}_{\text {mod }}=$ effect of parental education on the changes in the mediators over time; $\mathrm{b}_{\text {mod }}=$ association between mediators and $\mathrm{FV}$ intake when adjusted for the moderator; $\mathrm{ab}_{\mathrm{mod}}=$ mediated effect of mediators on the effect of parental education on the change in $\mathrm{FV}$ intake over time. SE, standard error. All analyses are adjusted for clustering effects and time, gender, parental education and treatment condition. $¥ \mathrm{p}<0.10 ;{ }^{*} \mathrm{p}<0.05 ;{ }^{* *} \mathrm{p}<0.01$; $* * * p<0.001$

\section{Discussion}

The present study shows an increase in SES disparity in FV intake among 10-12 year olds from 2001 to 2008, wherein low SES children had a steeper decline in FV intake than high SES children. This increase in SES disparity was partly mediated by an increasing SES disparity in accessibility and preferences, wherein high SES children had a steeper increase in accessibility and preferences than low SES children. Moreover, increases in accessibility and preferences over time were found to suppress the decrease in FV intake over time. This indicates that the decrease in FV intake would have been higher if accessibility and preferences had not increased over time. This points out that accessibility and preferences are relevant determinants of FV intake which confirms the findings of previous research [11]. The gender disparity regarding FV intake did not change from 2001 to 2008 .

Studies on how the socioeconomic disparities in eating behaviors have developed over time are limited. Previous observational studies on dietary behavior reveal that healthy eating habits decreases as the adolescents get older, and that the SES disparities increased [2]. In a recent review, adolescents' of lower SES had poorer diets compared to adolescents of higher SES in 14 out of 16 studies [25]. The authors concluded that the observed associations between SES and eating habits among adolescents seemed less robust than the association between SES and eating habits among adults. Within the FVMM study previous longitudinal analysis has shown an increased socioeconomic disparity in FV intake among adolescents as they aged from 12.5 (year 2002 ) to 15.5 years (year 2005). The difference in the socioeconomic disparities in FV intake among these adolescents increased from 1.3 times/week in 2002 (age 12.5, $\mathrm{p}=0.03$ ) to 2.4 times/week in 2005 (age 15.5, $\mathrm{p}<$ 0.001) [8]. The present study shows that the SES disparities in FV intake within the same age group (10-12 year olds) increased from 0.9 in 2001 to 2.4 times/week in 2008 (data not shown). A study on similar trends in SES differences in FV intake among Dutch schoolchildren recently reported that girls of mothers with lower educational level reported lower fruit intake in 2009 compared to 2003 (unpublished work by Fischer C, Brug J, Tak $\mathrm{N}$ and Te Velde S). This shows that there probably is a trend in the society towards greater SES disparities with regard to FV intake in two highly developed countries, Norway and the Netherlands. This trend might also explain at least parts of the age-trend reported above. Whether it is the increasing age or development in time which contributes most to these increased socioeconomic disparities needs further investigation.

Bere and colleagues [8] have previously reported that SES disparities regarding perceived accessibility and preferences for FV explains most of the SES differences observed in FV intake. The present study adds to this by showing that changes in accessibility and preferences also mediate parts of the increasing SES disparities regarding changes in $\mathrm{FV}$ intake within the same age group from 2001 to 2008, wherein high SES children had a higher increase in accessibility and preferences than low SES children.

This increasing disparities regarding SES differences in adolescents FV intake, accessibility and preferences of FV is the opposite trend of what the Norwegian government has been aiming for [14]. One effort of the Norwegian government in trying to reduce social disparities in health is a free school fruit scheme implemented at all secondary schools (grades 8-10) and all combined schools (1-10) from fall 2007. It is now legally established that all pupils in secondary schools receive a free fruit at school every school day [26]. This nation-wide free school fruit scheme has recently been evaluated within the FVMM project [19], using the same data set as the present study. A greater increase in fruit intake within the schools participating in the program (i.e. schools with grades $1-10,5$ out of the 27 schools) compared to the other schools was observed. In addition, it was indicated that the free fruit scheme was effective in increasing fruit intake in all groups at these schools (including boys and pupils of lower SES) as the interactions between intervention effect and gender and SES were not significant. However, this effect was probably 
not sufficient in order to limit the increasing socioeconomic disparities in the pupils' frequency of FV consumption, as presented in the present paper, during the same period. This might be because only a limited number of schools (5 out of 27) received free fruit. The results of Bere et al. [19] also showed that in schools not participating in any FV program the percentage of pupils eating FV at school 4-5 days per week increased by 12 percentage points among the pupils of high SES whereas there were no changes in the low SES group from 2001 to 2008, adding support to our findings in the present study.

The contradicting results on the time trend in FV intake found in the current study, compared to Bere et al. [19] may be explained by the methods used to assess FV intake. In the study referred to above, a 24-h recall was used to assess $\mathrm{FV}$ intake in order to assess the effect of the school fruit programs, while the current study used FFQ's to assess FV intake to be able to relate $\mathrm{FV}$ intake to accessibility and preferences. In the current study however, we observed an increase in intake of apples, oranges, pears and bananas from 2001 to 2008 (Table 2). This may reflect an increased intake of fruits at school, as the school fruit scheme mostly serves these kinds of fruits. The decline reported in consumption of other vegetables and other fruits and berries assessed by the FFQ's (Table 2) might be due to these questions being somehow vague. However, during the last decade there has been considerable publicity by the Norwegian government on promoting FV intake, also among children and adolescents. This might have contributed that the pupils of 2008 were more aware and able to report their FV intake compared to the 2001 pupils. A hypothesis might be that pupils of 2008 report to eat more FV on those occasions where they know they are served FV (school and dinner) and being less likely to over report on vague items such as 'other vegetables/fruits'.

A strength of the present study is that it includes pupils at two time points (2001 and 2008) from the same 27 randomly selected schools. There are some limitations to this study. First, the schools included were from only 2 out of 19 Norwegian counties. However, since the attrition analysis showed no significant differences between study sample and the 11 schools not participating in 2008 and since Norway is a rather homogenous country the results from this study can probably be generalized to all Norwegian counties. Second, the 2008 sample had a higher proportion of high SES pupils compared to the 2001 sample (i.e. in 2008 more of the parents reported a higher education level). A higher proportion of high SES pupils in the study sample for 2008 probably reflect the increasing educational level in the population [27]. However, it may also be that the proportionally less pupils in 2008 compared to 2001 had parental reported SES data and that research suggests that parents of high SES groups are more likely to respond to research requests. Third, most of the parents who filled out the questionnaires, and who's educational level was used to assess SES, were mothers (81.9\%). This might not reflect the all over family SES completely.

Our findings indicate the need for further research and enhanced efforts to reduce the socioeconomic disparities in adolescent FV intake. A next question would be to ask: How can we improve the accessibility at home and preferences among children and adolescents of low SES groups? There is clearly a need for intervention studies on increasing the children and adolescents accessibility and preferences, especially among those of the lower SES groups.

\section{Conclusions}

The results show an increase in social disparities from 2001 to 2008 in FV intake, accessibility and preferences of FV among adolescents aged 10-12 years. Accessibility and preferences mediated parts of the increase in SES disparity in FV intake.

\section{Funding}

The project was funded by the Norwegian Research Council (Grant number 185817/V50). The contribution of MMS was funded by Netherlands Organization for Health Research and Development (Grant number 121520002).

\section{Abbreviations}

FV: fruits and vegetables; GDP: gross domestic product; SES: socioeconomic status; FVMM: Fruits and Vegetables Make the Marks; ANOVA: Analysis of variance between groups; SPSS: Statistical Package for the Social Sciences; SE: standard error; Cl: confidence interval.

\section{Author details}

${ }^{7}$ Faculty of Health and Sport, University of Agder, Norway. ${ }^{2}$ Department of Nutrition, Faculty of Medicine, University of Oslo, Norway. ${ }^{3}$ Department of Public and Occupational Health, the EMGO Institute for Health and Care Research, $\mathrm{VU}$ University Medical Center, the Netherlands.

\section{Authors' contributions}

KIK conceived the study in 2001. EB conceived the study in 2008. EB and $\mathrm{MH}$ designed the current study. MH and MMS analyzed the data and all authors contributed to interpretation. $\mathrm{MH}$ drafted the manuscript and MMS, EB and KIK critically revised it. All authors approved of the final manuscript.

\section{Competing interests}

The authors declare that they have no competing interests.

Received: 26 January 2011 Accepted: 3 October 2011

Published: 3 October 2011

\section{References}

1. World Health Organization: Diet, Nutrition and the Prevention of Chronic Diseases. Joint WHO/FAO Expert Consultation. Geneva: WHO; 2003, WHO Technical Report Series no. 916. 
2. Lien N, Lytle LA, Klepp Kl: Stability in consumption of fruit, vegetables, and sugary foods in a cohort from age 14 to age 21. Prev Med 2001, 33:217-226.

3. Kelder SH, Perry CL, Klepp Kl, Lytle LL: Longitudinal tracking of adolescent smoking, physical activity, and food choice behaviors. Am J Public Health 1994, 84:1121-1126.

4. Andersen LF, Overby N, Lillegaard IT: Intake of fruit and vegetables among Norwegian children and adolescents. Tidsskr Nor Laegeforen 2004 124:1396-1398.

5. Yngve A, Wolf A, Poortvliet E, Elmadfa I, Brug J, Ehrenblad B, et al: Fruit and vegetable intake in a sample of 11-year-old children in 9 European countries: The Pro Children Cross-sectional Survey. Ann Nutr Metab 2005, 49:236-245

6. Sosial- og helsedirektoratet: Sosial- og helsedirektoratets handlingsplan mot sosiale ulikheter i helse: Gradientutfordringen. Oslo; 2005.

7. Holmboe-Ottesen $\mathrm{G}$, Wandel M, Mosdol A: Social inequality and diet. Tidsskr Nor Laegeforen 2004, 124:1526-1528.

8. Bere $\mathrm{E}$, van LF, Klepp Kl, Brug J: Why do parents' education level and income affect the amount of fruits and vegetables adolescents eat? Eur J Public Health 2008, 18:611-615.

9. Rasmussen M, Krolner R, Klepp KI, Lytle L, Brug J, Bere E, et al: Determinants of fruit and vegetable consumption among children and adolescents: a review of the literature. Part I: Quantitative studies. Int $J$ Behav Nutr Phys Act 2006, 3:22

10. Bere $\mathrm{E}, \mathrm{Klepp} \mathrm{Kl:Correlates} \mathrm{of} \mathrm{fruit} \mathrm{and} \mathrm{vegetable} \mathrm{intake} \mathrm{among}$ Norwegian schoolchildren: parental and self-reports. Public Health Nutr 2004, 7:991-998

11. Bere $\mathrm{E}$, Klepp Kl: Changes in accessibility and preferences predict children's future fruit and vegetable intake. Int J Behav Nutr Phys Act 2005, 2:15.

12. Bere $\mathrm{E}$, Brug J, Klepp Kl: Why do boys eat less fruit and vegetables than girls? Public Health Nutr 2008, 11:321-325.

13. Helse- og omsorgsdepartementet. St.meld. nr.20 (2006-2007): Nasjonal strategi for å utjevne sosiale helseforskjeller. Oslo: Helse- og omsorgsdepartementet; 2007

14. Helse- og omsorgsdepartementet: Handlingsplan for et bedre kosthold i befolkningen (2007-2011): Oppskrift for et sunnere kosthold. Oslo: Helseog omsorgsdepartementet; 2007

15. Nasjonalt råd for ernæring: Et sunt kosthold for god helse: Strategisk plan med forslag til tiltak for perioden 2005-2009 skrevet på oppdrag fra Sosial- og helsedirektoratet. Oslo: Sosial- og helsedirektoratet; 2005.

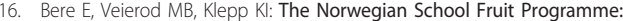
evaluating paid vs. no-cost subscriptions. Prev Med 2005, 41:463-470.

17. Bere $\mathrm{E}$, Veierod MB, Bjelland M, Klepp Kl: Free school fruit-sustained effect 1 year later. Health Educ Res 2006, 21:268-275.

18. Bere E, Veierod MB, Bjelland M, Klepp Kl: Outcome and process evaluation of a Norwegian school-randomized fruit and vegetable intervention: Fruits and Vegetables Make the Marks (FVMM). Health Educ Res 2006, 21:258-267.

19. Bere $\mathrm{E}$, Hilsen $\mathrm{M}$, Klepp Kl: Effect of the nationwide free school fruit scheme in Norway. Br J Nutr 2010, 1-6.

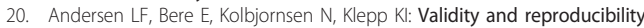
of self-reported intake of fruit and vegetable among 6th graders. Eur $\rfloor$ Clin Nutr 2004, 58:771-777.

21. Bere $\mathrm{E}$, Klepp Kl: Reliability of parental and self-reported determinants of fruit and vegetable intake among 6th graders. Public Health Nutr 2004, 7:353-356

22. MacKinnon DP: Introduction to Statistical Mediation Analysis New York: Erlbaum; 2008

23. Fairchild AJ, MacKinnon DP: A general model for testing mediation and moderation effects. Prev Sci 2009 , 10:87-99.

24. Twisk J: Applied Multilevel Analysis Cambridge University Press; 2006.

25. Hanson MD, Chen E: Socioeconomic status and health behaviors in adolescence: a review of the literature. J Behav Med 2007, 30:263-285.

26. Det kongelige kunnskapsdepartement: Ot.prp. nr. 40 (2007-2008): Om lov om endringar i opplæringslova og privatskolelova. Oslo: Det kongelige kunnskapsdepartement; 2008.

27. Statistisk sentralbyrå: Fakta om utdanning 2010 - nøkkeltall fra 2008. Oslo; doi:10.1186/1479-5868-8-108

Cite this article as: Hilsen et al:: Changes in 10-12 year old's fruit and vegetable intake in Norway from 2001 to 2008 in relation to gender and socioeconomic status - a comparison of two cross-sectional groups. International Journal of Behavioral Nutrition and Physical Activity 2011 8:108.

\section{Submit your next manuscript to BioMed Central and take full advantage of:}

- Convenient online submission

- Thorough peer review

- No space constraints or color figure charges

- Immediate publication on acceptance

- Inclusion in PubMed, CAS, Scopus and Google Scholar

- Research which is freely available for redistribution

Submit your manuscript at www.biomedcentral.com/submit
( Biomed Central 


\section{PAPER IV}

Predictors and mediators of differences in soft drink consumption according to gender and plans of further education among Norwegian secondary schoolchildren 



\title{
Predictors and mediators of differences in soft drinks consumption according to gender and plans of further education among Norwegian secondary-school children
}

\author{
Marit Hilsen ${ }^{1,2,3, *}$, Saskia J te Velde ${ }^{3}$, Elling Bere ${ }^{1}$ and Johannes Brug ${ }^{3}$ \\ 'Department of Public Health, Sport and Nutrition, Postboks 422, University of Agder, 4604 Kristiansand, \\ Norway: ${ }^{2}$ Department of Nutrition, Faculty of Medicine, University of Oslo, Oslo, Norway: ${ }^{3}$ Department of \\ Epidemiology \& Biostatistics and the EMGO Institute for Health and Care Research, VU University Medical \\ Centre, Amsterdam, the Netherlands
}

Submitted 8 March 2011: Accepted 11 October 2011

\begin{abstract}
Objective: To explore mediators of gender and educational differences in sugarsweetened soft drinks consumption (SDC) and whether gender and level of future education moderate the associations of accessibility, modelling, attitudes and preferences with SDC.

Design: A cross-sectional school-based survey within the Fruits and Vegetables Makes the Marks (FVMM) project from 2005.

Setting: The questionnaires were completed by the pupils in the classroom guided by a trained project worker during one class session. The questionnaire included questions on SDC (times/week), the potential mediators and moderators. Multilevel linear regression models were used to calculate the mediating and moderating effects.

Subjects: A total of 2870 children in 9th and 10 th grade (mean age 15.5 years) at thirty-three Norwegian secondary schools were included in the present study.

Results: Girls $(B=-1 \cdot 06)$ and pupils planning higher education $(B=-0 \cdot 69)$ reported lower frequency of SDC. The strongest mediators were accessibility and modelling for future educational plans differences (explaining alone respectively $69 \%$ and $44 \%$ ) and attitudes and preferences for gender differences (explaining alone respectively $57 \%$ and $51 \%$ ). Significant but small moderating effects were found, and all associations between the mediators and SDC were in the same direction for both genders and for those with and without plans of higher future education.

Conclusions: Preferences and modelling may contribute to gender and educational differences in SDC. The small moderating effects indicate that interventions aiming to reduce SDC can target the same mediators for boys and girls and children planning different levels of future education.
\end{abstract}

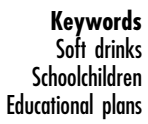

Sugar-sweetened carbonated soft drinks consumption (SDC) has been associated with increased energy intake and body weight, lower intake of several nutrients and an increased risk of type 2 diabetes $^{(1)}$, dental caries and potential enamel erosion ${ }^{(2)}$.

The WHO recommends a maximum of $10 \%$ of energy intake from free sugars ${ }^{(3)}$. A study among 8 th graders in Norway showed that $18 \%$ of energy intake came from free sugars; for $89 \%$ of the children more than $10 \%$ of energy intake was from free sugars, and soft drinks contributed $30 \%$ to total added sugar intakes ${ }^{(4)}$. Studies in other countries also show high sugar intakes among youth and have reported an increase in SDC among children and adolescents $^{(5)}$ as well as an increase in availability of soft drinks $^{(6)}$ in recent years.
Earlier studies further show that boys drink more soft drinks than girls ${ }^{(7,8)}$, that consumption of soft drinks increases with age $\mathrm{e}^{(5,8,9)}$ and that youth from lower socio-economic groups drink more soft drinks ${ }^{(7,10,11)}$. It has also been reported among younger adults that, compared with low consumers of sugar-sweetened soft drinks, the high consumption group has a lower proportion of physically active individuals and a higher proportion of regular smokers ${ }^{(12)}$. The Fruits and Vegetables Make the Marks (FVMM) project indicated that gender, educational plans, dieting, accessibility at home, parental and peer modelling, attitudes and preferences all were strong correlates of adolescents' SDC ${ }^{(7)}$. Preferences $^{(8)}$, attitudes ${ }^{(13-16)}$ and modelling ${ }^{(8,17,18)}$ have been found to be associated with SDC among adolescents in other studies as well. Furthermore, children attending 
M Hilsen et al.

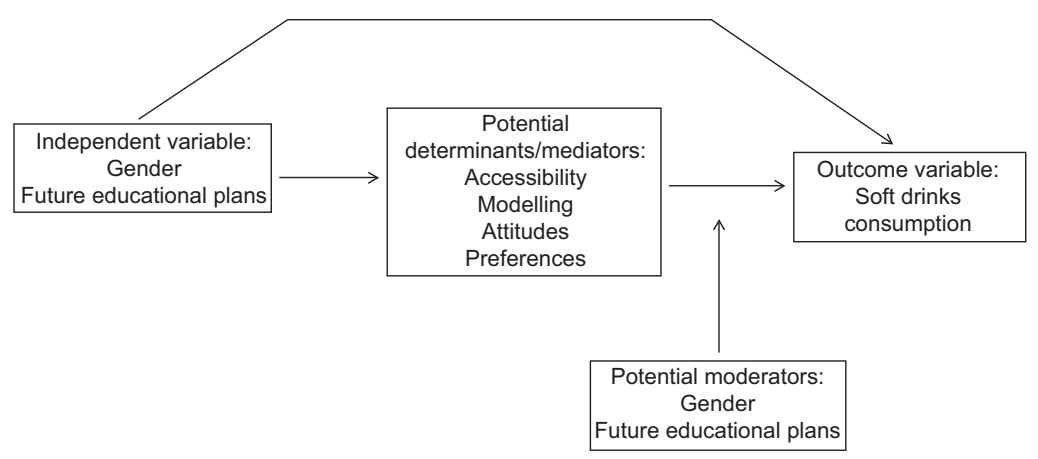

Fig. 1 Model of the potential determinants, mediators and moderators of soft drinks consumption

lower levels of education are more likely to drink soft drinks than higher education students ${ }^{(7)}$.

In order to reduce SDC among children and adolescents more insight is needed into what may explain the gender and educational differences in SDC. Based on health behaviour theory and the previous findings of other studies outlined above we know that the adolescents' perceived home accessibility, example behaviour by parents and friends (modelling), attitudes and preferences of soft drinks are associated with SDC. Additionally, given the fact that such potential determinants have also been found to differ according to gender and level of education, we aimed to explore these determinants/correlates further regarding whether they also were associated with gender and future educational plans in the present sample, and if these mediated the intake differences according gender and education. The aims of the present study were therefore to explore whether accessibility, modelling, attitudes and preferences can explain the differences in SDC according to gender and the pupils' anticipated level of secondary education. The EnRG framework ${ }^{(19)}$ posits that sociodemographic variables can importantly moderate determinant-behaviour relationships. Gender as well as level of education has been found to be an important moderator of health behaviour change in earlier studies, and interventions are often tailored to level of education or gender. Due to the large gender and socioeconomic differences in SDC we wanted to explore whether gender and the pupils' further educational plans moderate the association between the potential mediators and SDC in the present study. The study therefore also explored whether the associations of accessibility, modelling, attitudes and preferences with SDC differ according to gender and level of anticipated further education (Fig. 1).

\section{Methods}

\section{Study sample and procedure}

The data are from the third follow-up measurement (2005 survey) of the Fruits and Vegetables Make the Marks
(FVMM) project. Pupils from 9th and 10th grade (mean age estimated to $15 \cdot 5$ years) of thirty-three lower secondary schools in Hedmark and Telemark counties participated. A total of 2870 pupils completed the school-based questionnaire with $51 \cdot 1 \%$ boys, $51 \cdot 1 \%$ th graders and $49 \cdot 1 \%$ pupils who planned to enrol in higher levels of further education after graduation from lower secondary school. The questionnaire was completed by the pupils in the classroom guided by a trained project worker in one school class session ( $45 \mathrm{~min}$ ).

\section{Measurements}

The questions on potential determinants/mediators in the survey questionnaire were based on focus groups interviews among 9th and 10th graders and a pre-test of the questionnaire $^{(7)}$. Frequency of SDC, home and school social and physical environmental and personal potential determinants of SDC were included in the questionnaire, as well as sociodemographic factors and gender.

\section{Main outcome variable: frequency of sugar-sweetened soft drinks consumption}

Two separate questions were included in the questionnaire to be able to distinguish between the pupils' consumption of sugar-sweetened soft drinks and artificially sweetened soft drinks. Weekly frequency of SDC among the pupils was assessed with one question: 'How often do you drink soft drinks?' The response categories for this question had ten alternatives ranging from 'never', 'less than once per week', 'once per week' ... to 'every day' and 'several times per day'. The score of this variable ranged from 0 (never), 0.5 (less than once per week), 1 (once per week) ... to 7 (every day) and 10 (several times per day). Test-retest results from a study among 6th graders ${ }^{(20)}$ showed an intraclass correlation of 0.72 between two assessments $14 \mathrm{~d}$ apart.

\section{Potential moderating variables: sociodemographic factors}

The pupils were asked to indicate their plans for further education (future education) after graduation from secondary 
school: 'university or college', 'technical or vocational education', 'no further education' and 'others'. This variable was dichotomized into higher education (university/ college; score $=1$ ) or not $($ score $=0)$. The pupils reported their gender ( girl, score $=1$; boy, score $=0$ ).

\section{Potential mediators}

Perceived accessibility at home of soft drinks was assessed by three questions (Cronbach's $\alpha=0 \cdot 70^{(7)}$ ). Modelling, i.e. descriptive norms from important others, was assessed with four items (Cronbach's $\alpha=0 \cdot 68^{(7)}$ ). Attitudes was assessed by three statements (Cronbach's $\alpha=0 \cdot 65^{(7)}$ ). For these mediators, mean scores were calculated if at least two items were completed, excluding thirty-nine, eighty-six and thirty-six pupils for accessibility, modelling and attitudes, respectively. Preferences was assessed by one question. The questions/statements, ranges and scores of all the potential mediators are presented in the Appendix.

\section{Statistical analyses}

First, regression models were used to estimate the overall relationship of future education and gender with SDC (path c; Fig. 2). Second, the relationship of future education plans and gender with the potential mediators (path a) was estimated. Third, the relationship between the potential mediators and SDC (path b) was calculated in a model including the mediator and the predictor. This also provided the direct relationship of future education and gender with SDC (path $\mathrm{c}^{\prime}$ ). Mediated effects were found by means of the product-of-coefficients method ${ }^{(21)}$. The standard error term was calculated by the equation ${ }^{(22)}$ : $\mathrm{SE}=\sqrt{b^{2} s_{a}^{2}+a^{2} s_{b}^{2}+s_{a}^{2} s_{b}^{2}}$, where $a$ and $b$ are unstandardized regression coefficients and $s_{a}$ and $s_{b}$ are their standard errors. The SE was used to construct a 95\% confidence interval for the mediated effects. Single and multiple mediator models were run and proportion mediated was calculated as $a \times b / c$ and as $\sum(a \times b) / c$.

To allow interpretation of first-order effects of the moderator (future education or gender) and predictor as average effects, the predictor (accessibility, modelling, attitudes and preferences) variables were standardized. Interaction terms were calculated between the standardized predictor variables and the potential moderator. To test whether future education and/or gender were moderators of the association of accessibility/modelling/attitudes/ preferences with SDC, a three-step approach was applied. The standardized variable ( $Z$-score) of the predictor was entered first, in the second step the moderator variable was entered, and in the third step the interaction term was included. The effect size was calculated by subtracting $R_{1}$ square from $R_{2}$ square ${ }^{(23)}$. We used a significance level for the moderated effects of $\alpha=0 \cdot 1$.

All analyses with gender as the predictor or moderator variable were adjusted for future education and grade, and all analyses regarding future education were adjusted for gender and grade. The statistical analyses were conducted using the SPSS statistical software package version 17 (SPSS Inc., Chicago, IL, USA).

\section{Results}

\section{Sample characteristics}

Pupils with higher future education plans and girls reported a lower mean SDC frequency compared with pupils without plans of higher education and boys (Table 1). Pupils not planning to enrol in higher education and boys also had higher scores on all potential mediators.

\section{Mediation of the gender-sugar-sweetened soft drinks consumption association}

The overall association between gender and SDC confirmed that girls had lower consumption frequency than boys (regression coefficient $B=-1 \cdot 06,95 \%$ CI $-1 \cdot 30$, $-0 \cdot 83$; Table 2 , path c). Table 2 also shows the associations between gender and the potential mediators (path a), the associations between the potential mediators and SDC (path b) and the mediated effects (ab). Preferences explained alone $56.9 \%$ of the variation while attitudes, accessibility and modelling explained alone $51.0 \%$, $27 \cdot 3 \%$ and $12 \cdot 5 \%$, respectively. Combined the mediators explained $63 \%$ of the gender variation in SDC. The direct effect of gender on SDC was still significant after adjusting for the mediators (Table 2, path $\mathrm{c}^{\prime}$ ).

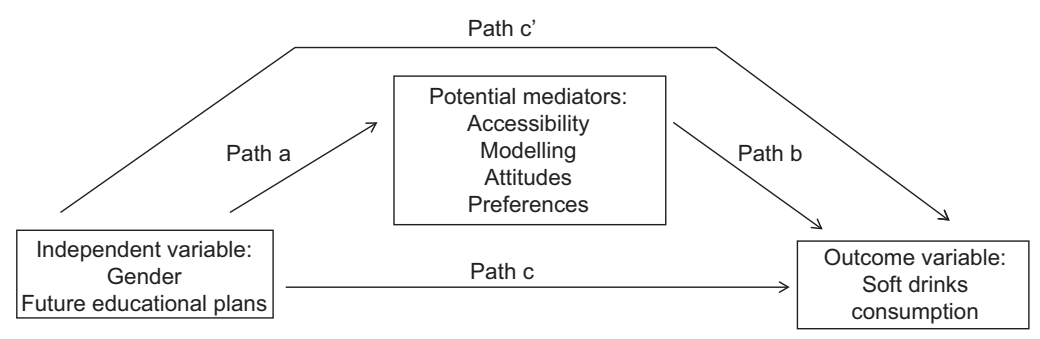

Fig. 2 Model of the mediation paths in the association between gender/future education plans and soft drinks consumption 
Table 1 Soft drinks consumption (times/week, mean and standard deviation) and the potential predictors and mediators by gender and future educational plans: Norwegian 9th and 10th graders ( $n 2870$, mean age 15.5 years), Fruits and Vegetables Makes the Marks (FVMM) project, 2005

\begin{tabular}{|c|c|c|c|c|c|}
\hline & $\begin{array}{l}\text { Number of } \\
\text { questions }\end{array}$ & $\begin{array}{c}\text { Range per } \\
\text { question }\end{array}$ & & Mean & SD \\
\hline \multirow[t]{4}{*}{ Soft drinks consumption } & \multirow[t]{4}{*}{1} & \multirow[t]{4}{*}{$0-10$} & No plans of higher education & $3 \cdot 2$ & $2 \cdot 7$ \\
\hline & & & Plans of higher education & $2 \cdot 4$ & $2 \cdot 2$ \\
\hline & & & Boys & $3 \cdot 3$ & $2 \cdot 6$ \\
\hline & & & Girls & $2 \cdot 3$ & $2 \cdot 2$ \\
\hline \multirow[t]{4}{*}{ Accessibility } & \multirow[t]{4}{*}{3} & \multirow[t]{4}{*}{$0-10$} & No plans of higher education & $6 \cdot 8$ & $5 \cdot 1$ \\
\hline & & & Plans of higher education & $5 \cdot 6$ & $4 \cdot 6$ \\
\hline & & & Boys & $6 \cdot 8$ & 4.9 \\
\hline & & & Girls & $5 \cdot 7$ & $5 \cdot 0$ \\
\hline \multirow[t]{4}{*}{ Modelling } & \multirow[t]{4}{*}{4} & \multirow[t]{4}{*}{$0-10$} & No plans of higher education & $10 \cdot 6$ & $6 \cdot 8$ \\
\hline & & & Plans of higher education & $8 \cdot 3$ & $7 \cdot 0$ \\
\hline & & & Boys & $10 \cdot 0$ & $6 \cdot 3$ \\
\hline & & & Girls & $9 \cdot 1$ & $6 \cdot 3$ \\
\hline \multirow[t]{4}{*}{ Attitudes } & \multirow[t]{4}{*}{3} & \multirow[t]{4}{*}{$-2-2$} & No plans of higher education & $-1 \cdot 3$ & $3 \cdot 2$ \\
\hline & & & Plans of higher education & $-2 \cdot 2$ & $2 \cdot 9$ \\
\hline & & & Boys & -0.9 & $3 \cdot 2$ \\
\hline & & & Girls & $-2 \cdot 5$ & $2 \cdot 8$ \\
\hline \multirow[t]{4}{*}{ Preferences } & \multirow[t]{4}{*}{1} & \multirow[t]{4}{*}{$0-10$} & No plans of higher education & $7 \cdot 9$ & $2 \cdot 7$ \\
\hline & & & Plans of higher education & $7 \cdot 2$ & $2 \cdot 3$ \\
\hline & & & Boys & $8 \cdot 2$ & $2 \cdot 4$ \\
\hline & & & Girls & $6 \cdot 8$ & $3 \cdot 0$ \\
\hline
\end{tabular}

\section{Mediation of the future education-sugar-} sweetened soft drinks consumption association

The overall association between future education and SDC showed that pupils planning to enrol in higher education reported lower frequency of consumption ( $B=-0 \cdot 69,95 \%$ CI $-0 \cdot 93,-0 \cdot 45$; Table 3, path c). Table 3 shows the associations between future education and the potential mediators (path a), the associations between the potential mediators and SDC (path b) and the mediated effects (ab). All mediated effects were significant, with modelling explaining alone $69 \cdot 1 \%$, while accessibility, preferences and attitudes explained alone $43 \cdot 7 \%, 30 \cdot 5 \%$ and $29 \cdot 6 \%$, respectively. Together, the mediators explained $80 \%$ of the variation in SDC. The direct effect of future education on SDC was not significant after adjusting for the mediators (Table 3, path $\mathrm{c}^{\prime}$ ).

\section{Gender as a moderator of the association} between the potential determinants and sugarsweetened soft drinks consumption

Significant interactions between gender and accessibility $(P=0 \cdot 028)$, gender and modelling $(P=0 \cdot 003)$ and gender and attitudes $(P=0 \cdot 033)$ were found. Stratification by gender showed that the association between attitudes and SDC was stronger among girls $(B=1 \cdot 25,95 \%$ CI $1 \cdot 11$, $1 \cdot 39)$ than boys $(B=1 \cdot 00,95 \%$ CI $0.83,1 \cdot 16)$. The association of accessibility with SDC was stronger for boys $(B 1 \cdot 57,95 \% \mathrm{CI} 1 \cdot 41,1 \cdot 73)$ than girls $(B=1 \cdot 37,95 \%$ CI $1 \cdot 25,1 \cdot 48)$. Also the association of modelling with SDC was stronger for boys $(B=1 \cdot 55,95 \%$ CI $1 \cdot 39,1 \cdot 71)$ compared with girls $(B=1 \cdot 26,95 \%$ CI $1 \cdot 12,1 \cdot 48)$. The differences in explained variances $\left(R^{2}\right)$ of the potential mediators were small, ranging from $0 \cdot 001$ for preferences to $0 \cdot 004$ for modelling.

\section{Future education as a moderator of the association between the potential determinants and sugar-sweetened soft drinks consumption}

Significant interactions between future education and modelling $(P=0 \cdot 038)$, future education and attitudes $(P=0 \cdot 001)$ and future education and preferences $(P=0 \cdot 001)$ were found. Stratification by educational plans showed that the association between modelling and SDC was stronger among pupils with plans of future higher education ( $B=1 \cdot 56,95 \%$ CI $1 \cdot 40,1 \cdot 71)$ than among pupils without plans of such future education ( $B=1 \cdot 30,95 \%$ CI $1 \cdot 51,1 \cdot 45)$. The association of attitudes with SDC was stronger among pupils without plans of higher education $(B=1 \cdot 29,95 \% \mathrm{CI}$ $1 \cdot 12,1 \cdot 45)$ compared with pupils with plans of higher education $(B=0 \cdot 92,95 \% \mathrm{CI} 0 \cdot 78,1 \cdot 07)$. Also the association of preferences with SDC was stronger for pupils without plans of higher education $(B=1 \cdot 35,95 \%$ CI $1 \cdot 16,1 \cdot 53)$ than for pupils with plans of higher education $(B=0 \cdot 99,95 \% \mathrm{CI} 0 \cdot 86$, $1 \cdot 13)$. The effect sizes, measured by the differences in explained variances $\left(R^{2}\right)$ of the potential mediators, were small, ranging from 0 for accessibility to 0.006 for attitudes. This means that the interaction effect accounts for up to $0.6 \%$ of the variance in SDC.

\section{Discussion}

The present study supports earlier findings regarding gender and educational differences in SDC and further suggests that these differences were strongly associated with gender differences in attitudes and preferences and educational differences in accessibility and modelling. Significant, moderating effects were found. The association between attitudes and SDC was stronger for girls, 
Soft drinks intake among Norwegian children

5

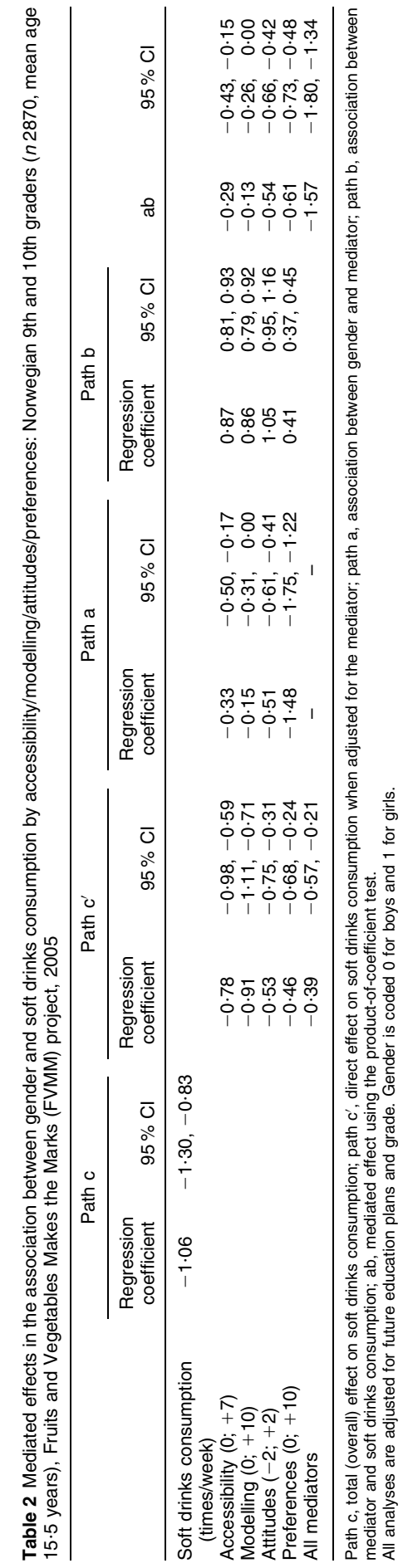

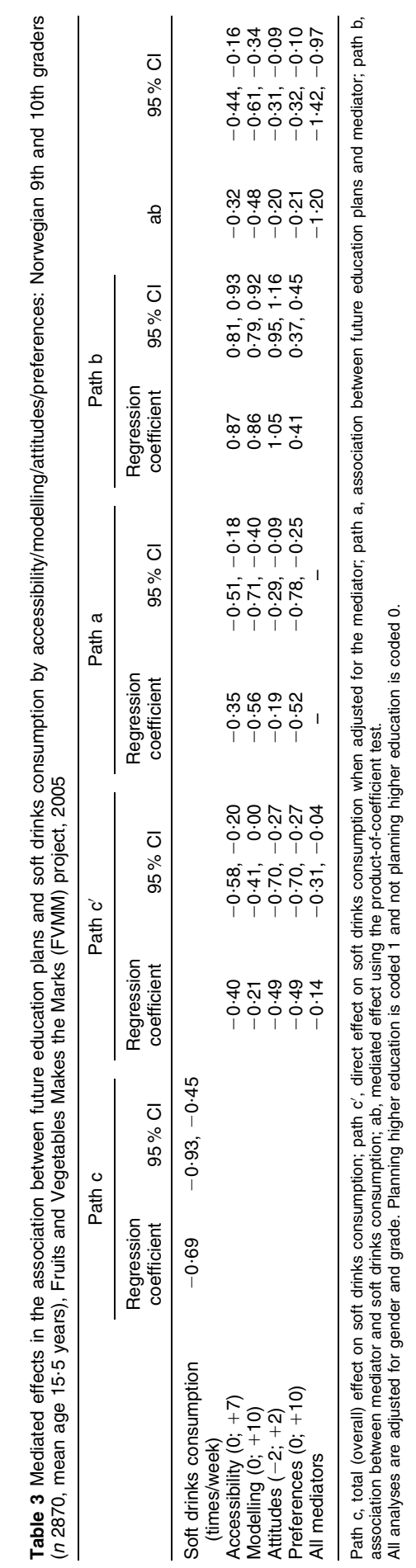


while the association between accessibility (and modelling) and SDC was stronger for boys. The association between modelling and SDC was stronger for pupils with plans of higher education, while the association between preferences (and attitudes) and SDC was stronger for pupils without plans of higher education. However, although gender and future education plans statistically significantly moderated these associations the moderation effects were too minor to be practically relevant; and the associations between mediators and SDC were always in the same direction for both genders and for those with and without future education plans. A previous review reported that gender was the most convincing moderator regarding intervention studies, where in general girls responded better to interventions addressing energy balance-related behaviours than boys ${ }^{(22)}$. However, the two included studies on soft drinks consumption showed mixed results ${ }^{(24,25)}$, with only one showing a significant moderating intervention effect by gender ${ }^{(25)}$. Our hypothesis that gender and education plans would moderate the association between presumed determinants of SDC and intakes was thus not supported by the data. This is of importance for interventions and policies; the results of our study do not appear to justify targeted approaches - i.e. different messages or approaches according to gender or education plans - in interventions aiming to reduce SDC in secondary-school pupils in Norway.

Disparities in SDC in relation to gender ${ }^{(7,8,10,11,17)}$ and level of education as well as other indicators of socioeconomic position $^{(7,10,11)}$ have been well documented. However, no studies explored what could explain the relationship between gender/indicators of socio-economic position and SDC. Earlier, preferences and perceived accessibility at home had been reported to be the strongest mediator of respectively gender ${ }^{(7)}$ and parental education disparities in fruit and vegetable consumption among adolescents in Norway ${ }^{(26)}$

In the current study, modelling by family and friends was not only associated with SCD, but also with future educational plans, and identified as a significant mediator. If indeed pupils with no plans for higher future education live in families or have close friends of lower socio-economic position, it can be expected that their family and friends engage in more unhealthy behaviours, e.g. high SDC. It is well known that family and friends' socio-economic position is related to engagement in healthy behaviours ${ }^{(6,11)}$. Future intervention programmes addressing educational disparities in SDC may therefore need to take into account the pupils' accessibility and their family and friends' behaviours. That is, such intervention programmes should especially be focused on reducing accessibility of SDC in the home and school environments: banning of soft drinks vending machines in schools, for example, and try to provide positive role models in the home and school environment.

In addition to being associated with SDC, preferences was also associated with gender, and found to be a mediator of the gender-SDC association. Preference has also been reported as the strongest mediator of the association between gender and fruit and vegetable intake ${ }^{(27)}$. Preference is a strong driver of intake, and our finding suggests that success in interventions to reduce SDC will be harder among boys.

The present study has some limitations. The reliability of the specific SDC intake was assessed (test-retest reliability was relatively high; $r=0 \cdot 72$ ) and the relative validity has been assessed among 6th graders using similar frequency questions for a range of food and drink intakes indicating acceptable validity ${ }^{(20)}$, but the relative validity of the specific questions used in the present study was not tested. The current study is based on cross-sectional data. In order to explore further and gain more insight to whether the potential mediators really can explain the observed variance in SDC and whether gender and educational plans are significant moderators, longitudinal analyses as well as intervention studies are needed.

\section{Conclusions}

Accessibility, parental and peer modelling, attitudes and preferences were the strongest mediators of educational and gender differences in SDC in Norwegian secondaryschool students. This suggests that future interventions should address modelling and preferences in order to decrease the gender and SES disparities in SDC intake. Lack of substantial moderation indicates that interventions on reducing SDC for girls and boys, and students planning to attend higher and lower levels of education, should target the same mediators, namely accessibility, modelling, attitudes and preferences.

\section{Acknowledgements}

The project was funded by the Norwegian Research Council. The authors declare that they have no competing interests. E.B. conceived the 2005 survey of the FVMM project. M.H., S.J.t.V. and J.B. designed the present study. M.H. and S.J.t.V. analysed the data. All authors contributed to the interpretation. M.H. drafted the manuscript and S.J.t.V., J.B. and E.B. critically revised it. All authors approved of the final manuscript.

\section{References}

1. Vartanian LR, Schwartz MB \& Brownell KD (2007) Effects of soft drink consumption on nutrition and health: a systematic review and meta-analysis. Am J Public Health 97, 667-675.

2. Tahmassebi JF, Duggal MS, Malik-Kotru G et al. (2006) Soft drinks and dental health: a review of the current literature. $J$ Dent 34, 2-11.

3. World Health Organization (2003) Diet, Nutrition and the Prevention of Chronic Diseases. Joint WHO/FAO Expert 
Consultation. WHO Technical Report Series no. 916. Geneva: WHO.

4. Overby NC, Lillegaard IT, Johansson L et al. (2004) High intake of added sugar among Norwegian children and adolescents. Public Health Nutr 7, 285-293.

5. Rampersaud GC, Bailey LB \& Kauwell GP (2003) National survey beverage consumption data for children and adolescents indicate the need to encourage a shift toward more nutritive beverages. J Am Diet Assoc 103, 97-100.

6. Naska A, Bountziouka V \& Trichopoulou A (2010) Soft drinks: time trends and correlates in twenty-four European countries. A cross-national study using the DAFNE (Data Food Networking) databank. Public Health Nutr 13, 1346-1355.

7. Bere E, Glomnes ES, te Velde SJ et al. (2008) Determinants of adolescents' soft drink consumption. Public Health Nutr 11, 49-56.

8. Grimm GC, Harnack L \& Story M (2004) Factors associated with soft drink consumption in school-aged children. $J \mathrm{Am}$ Diet Assoc 104, 1244-1249.

9. Lien N, Lytle LA \& Klepp KI (2001) Stability in consumption of fruit, vegetables, and sugary foods in a cohort from age 14 to age 21. Prev Med 33, 217-226.

10. Nilsen SM, Krokstad S, Holmen TL et al. (2010) Adolescents' health-related dietary patterns by parental socio-economic position, the Nord-Trondelag Health Study (HUNT). Eur J Public Health 20, 299-305.

11. Vereecken CA, Inchley J, Subramanian SV et al. (2005) The relative influence of individual and contextual socioeconomic status on consumption of fruit and soft drinks among adolescents in Europe. Eur J Public Health 15, 224-232.

12. Kvaavik E, Andersen LF \& Klepp KI (2005) The stability of soft drinks intake from adolescence to adult age and the association between long-term consumption of soft drinks and lifestyle factors and body weight. Public Health Nutr $\mathbf{8}$, 149-157.

13. de Bruijn GJ, Kremers SP, de VH et al. (2007) Associations of social-environmental and individual-level factors with adolescent soft drink consumption: results from the SMILE study. Health Educ Res 22, 227-237.

14. Kassem NO, Lee JW, Modeste NN et al. (2003) Understanding soft drink consumption among female adolescents using the Theory of Planned Behavior. Health Educ Res 18, 278-291.

15. Kassem NO \& Lee JW (2004) Understanding soft drink consumption among male adolescents using the theory of planned behavior. J Behav Med 27, 273-296.

16. van der Horst K, Kremers S, Ferreira I et al. (2007) Perceived parenting style and practices and the consumption of sugar-sweetened beverages by adolescents. Health Educ Res 22, 295-304.

17. Denney-Wilson E, Crawford D, Dobbins T et al. (2009) Influences on consumption of soft drinks and fast foods in adolescents. Asia Pac J Clin Nutr 18, 447-452.

18. Feunekes GI, de Graaf C, Meyboom S et al. (1998) Food choice and fat intake of adolescents and adults: associations of intakes within social networks. Prev Med 27, 645-656.

19. Kremers SP, de Bruijn GJ, Visscher TL et al. (2006) Environmental influences on energy balance-related behaviors: a dual-process view. Int J Behav Nutr Phys Act 3, 9.

20. Andersen LF, Bere E, Kolbjornsen N et al. (2004) Validity and reproducibility of self-reported intake of fruit and vegetable among 6th graders. Eur I Clin Nutr 58, 771-777.

21. MacKinnon DP (2008) Introduction to Statistical Mediation Analysis. New York: Erlbaum.

22. Kenney DA, Kashy DA \& Bolger N (1998) The Handbook of Social Psychology, th ed. Boston, MA: McGraw-Hill.

23. Jaccard J, Turrisi R \& Wan CK (1990) Interaction Effects in Multiple Regression. London: SAGE Publications.

24. Haerens L, De BI, Maes L et al. (2007) The effects of a middle-school healthy eating intervention on adolescents' fat and fruit intake and soft drinks consumption. Public Health Nutr 10, 443-449.

25. Singh AS, Chin APM, Brug J et al. (2009) Dutch obesity intervention in teenagers: effectiveness of a school-based program on body composition and behavior. Arch Pediatr Adolesc Med 163, 309-317.

26. Bere E, van Lenthe F, Klepp KI et al. (2008) Why do parents' education level and income affect the amount of fruits and vegetables adolescents eat? Eur J Public Health 18, 611-615.

27. Bere E, Brug J \& Klepp KI (2008) Why do boys eat less fruit and vegetables than girls? Public Health Nutr 11, 321-325.

\section{Appendix}

Overview of the questions and statements used for assessing the potential mediators of soft drinks consumption and the response alternatives/scores

\begin{tabular}{|c|c|c|c|}
\hline Potential mediators & Questions/statements & $\begin{array}{l}\text { Response } \\
\text { alternatives }(n)\end{array}$ & Response alternatives (scores) \\
\hline Accessibility & $\begin{array}{l}\text { 1. How often are soft drinks to be found in your home? } \\
\text { 2. How often are you served soft drinks for dinner? } \\
\text { 3. How often does your mother/father serve you } \\
\text { soft drinks besides dinner? }\end{array}$ & 10 & $\begin{array}{l}\text { never }(0) \\
\text { less than once per month }(0 \cdot 1) \\
\text { less than once per week }[0.5] \\
\text { once per week }(1) \\
\ldots \text { to } \\
\text { every day ( } 7)\end{array}$ \\
\hline Modelling & $\begin{array}{l}\text { 1. How often does your mother/father/siblings/best } \\
\text { friend drink soft drinks? }\end{array}$ & 10 & $\begin{array}{l}\text { never }(0) \\
\text { less than once per week }(0.5) \\
\text { once per week }(1) \\
\ldots \text { to } \\
\text { every day }(7) \\
\text { several times per day }(10)\end{array}$ \\
\hline Attitudes & $\begin{array}{l}\text { 1. Soft drinks are well suited at meals } \\
\text { 2. Soft drinks are well suited as a thirst-quencher } \\
\text { 3. Soft drinks are good for your health }\end{array}$ & 5 & $\begin{array}{l}\text { I totally agree }(2) \\
\ldots \text { to } \\
\text { I totally disagree }(-2)\end{array}$ \\
\hline Preferences & 1. On a scale from 0 to 10 , how tasty do you find soft drinks? & 11 & 0 to 10 \\
\hline
\end{tabular}



APPENDIX I

Pupils follow-up 3 questionnaire

(Norwegian) 



\section{Spørreskjema om}

\section{frukt, grønt og brus og noen andre matvarer}

Frukt og grønt i 6. er et forskningsprosjekt som omhandler skoleelevers forbruk av og holdninger til forskjellige mat- og drikkevarer. Vi er spesielt interessert i frukt, grønnsaker og brus. Prosjektet er finansiert av Norges forskningsråd.

Dette skjemaet skal besvares på en tirsdag, onsdag, torsdag eller fredag, da gårsdagen skal være en skoledag.

Det er helt frivillig å svare på disse spørsmålene, og du kan trekke deg når som helst. Vi vil gjerne at du besvarer alle spørsmålene, men er det spørsmål du ikke kan eller vil svare på kan du la være. Alle svarene er hemmelige. Du skal ikke skrive navnet ditt på skjemaet.

Skriv helst med gråblyant - da kan du viske bort hvis du ombestemmer deg.

Lag fine tydelige kryss!

TAKK FOR HJELPEN!

Knut-Inge Klepp professor
Elling Bere

postdok

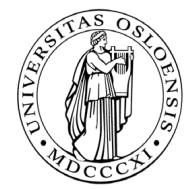

\section{UNIVERSITETET I OSLO}

\section{DET MEDISINSKE FAKULTET}

Avdeling for ernæringsvitenskap

$\mathrm{v} /$ Elling Bere

Postboks 1046 Blindern

0316 Oslo

Telefon: 22851372

Telefaks: 22851341

E-post: e.t.bere@medisin.uio.no
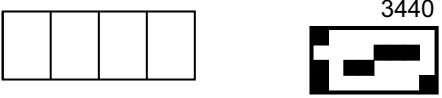


\section{Er du gutt eller jente?}

$\square$ Gutt

Jente

\section{Abonnerer du på Skolefrukt?}

$\mathrm{Ja}$

Nei

\section{Hvilket klassetrinn er du i?}

9. klassetrinn

10. klassetrinn
4. Hvilken dag er det i dag?

$\square$ Mandag

$\square$ Tirsdag

$\square$ Onsdag

$\square$ Torsdag

$\square$ Fredag

5. Var du på skolen i går?

$\mathrm{Ja}$

$\square$ Nei

\section{Del $A$ (begynner på neste side)}

\section{Hvordan svare på del A?}

Dagen i går er delt opp i 5 perioder: Frokost, på skolen, etter skolen, middag og kvelds.

- Kryss av for om du spiste de forskjellige matvarene til de forskjellige tidene eller ikke.

- For frukt, grønnsaker, poteter og juice skal du også skrive ned HVA du spiste og HVOR MYE. Under følger en beskrivelse av hvordan du skal gjøre dette.

- For brus, snop, nudler og boller skal du kun krysse av for om du spiste det eller ikke. Her skal du altså IKKE skrive ned hva og hvor mye.

Hvordan skrive ned HVA og HVOR MYE for frukt, grønnsaker, poteter og brus:

Frukt og bær måles i antall (f.eks. ett eple, en banan) eller i porsjon (f.eks. en porsjon fruktsalat)

Grønnsaker måles i antall (f.eks. en gulrot) eller i porsjon (f.eks. en porsjon salat, en porsjon brokkoli)

Poteter måles i antall (f.eks. 2 poteter) eller i porsjon (f.eks. en porsjon potetstappe eller en porsjon stekte poteter)

Juice måles i antall glass (f.eks. ett glass eplejuice)

Hvis du spiste noe som ikke kan måles i stykker, porsjoner eller antall, må du beskrive best mulig hvor mye du spiste (f.eks. 2 never bringebær, $1 \frac{1}{2}$ skive kålrot eller 3 ringer paprika).

Brus med sukker er f.eks. Solo, Pepsi, Fanta, Coca-Cola.

Brus uten sukker er f.eks. Solo lett, Solo pluss, Pepsi MAX, Coca-Cola light, Tab X-tra. 
1. Spiste du frokost $i$ går tidlig?

$\square \mathrm{Ja} \square$ Nei

2. Spiste du frukt eller bar i går tidlig?

$\mathrm{Ja}$

$\square$ Nei

Hvis ja, skriv ned hva slags og hvor mye frukt og bær du spiste her:

3. Spiste du grønnsaker i går tidlig?

$\square$ Ja $\square$ Nei

Hvis ja, skriv ned hva slags og hvor mye grønnsaker du spiste her:

4. Drakk du juice i går tidlig?

Ja $\square$ Nei

Hvis ja, skriv ned hva slags og hvor mye juice du drakk her:

5. Drakk du vann i går tidlig?
$\square$ Ja $\square$ Nei

6. Drakk du brus MED sukker i går tidlig?

NB: For spørsmål 5-10 skal du IKKE skrive hva og

$\square$ Ja $\square$ Nei

7. Drakk du brus UTEN sukker i går tidlig?

$\square$ Ja $\square$ Nei

8. Spiste du nudler (f.eks. Mr Lee) i går tidlig?

$\square$ Ja $\square$ Nei

9. Spiste du boller, muffins, kake eller annen søt gjærbakst i går tidlig?

$\square$ Ja $\square$ Nei

10. Spiste du snop, potetgull eller lignende i går tidlig?

$\square$ Ja $\square$ Nei 
11. Spiste du skolemat/lunsj i går?

$\square$ Ja $\square$ Nei

12. Spiste du frukt eller bær til skolematen eller i friminuttene i går?

\section{På skolen}

Hvis ja, skriv ned hva slags og hvor mye frukt og bær du spiste her:

13. Spiste du grønnsaker til skolematen eller i friminuttene i går?

$\square$ Ja $\square$ Nei

Hvis ja, skriv ned hva slags og hvor mye grønnsaker du spiste her:

14. Drakk du juice til skolematen eller $i$ friminuttene $i$ går?

$\square$ Ja $\square$ Nei

Hvis ja, skriv ned hva slags og hvor mye juice du drakk her:

15. Drakk du vann til skolematen eller $i$ friminuttene $i$ går?

$\square$ Ja $\square$ Nei

NB: For spørsmål 15-20 skal du IKKE skrive hva og hvor mye du spiste/drakk

16. Drakk du brus MED sukker til skolematen eller i friminuttene i går?

$\square \mathrm{Ja} \square$ Nei

17. Drakk du brus UTEN sukker til skolematen eller i friminuttene i går?

$\square$ Ja $\square$ Nei

18. Spiste du nudler (f.eks. Mr Lee) som skolemat eller i friminuttene i går?

$\square$ Ja $\square$ Nei

19. Spiste du boller, muffins, kake eller annen søt gjærbakst som skolemat eller i friminuttene i går?

$\square$ Ja $\square$ Nei

20. Spiste du snop, potetgull eller lignende i skoletiden i går?

$\square$ Ja $\square$ Nei 
21. Spiste du frukt eller bær etter skoletid, men før middag i går?

\section{Etter skolen}

Hvis ja, skriv ned hva slags og hvor mye frukt og bær du spiste her:

22. Spiste du grønnsaker etter skoletid, men før middag i går?

$\square$ Ja $\square$ Nei

Hvis ja, skriv ned hva slags og hvor mye grønnsaker du spiste her:

this ja, skiv ned hva slags og hvor mye gronnsaker du spiste her:

23. Drakk du juice etter skoletid, men for middag i går?

$\square$ Ja $\square$ Nei

Hvis ja, skriv ned hva slags og hvor mye juice du drakk her:

24. Drakk du vann etter skoletid, men for middag i går?

$\square$ Ja $\square$ Nei

25. Drakk du brus MED sukker etter skoletid, men før middag i går?

$\square$ Ja $\square$ Nei

26. Drakk du brus UTEN sukker etter skoletid, men for middag i går?

$\square$ Ja $\square$ Nei

27. Spiste du nudler (f.eks. Mr Lee) etter skoletid, men før middag i går?

$\square \mathrm{Ja} \square$ Nei

28. Spiste du boller, muffins, kake eller annen søt gjærbakst etter skoletid, men før middag i går?

$\square$ Ja $\square$ Nei

29. Spiste du snop, potetgull eller lignende etter skoletid, men for middag i går?

$\square \mathrm{Ja} \square$ Nei
NB: For spørsmål 24-29 skal du IKKE skrive hva og hvor mye du spiste/drakk 
30. Spiste du middag i går?

$\square$ Ja $\square$ Nei

31. Spiste du potet til middag i går?

Middag

Hvis ja, skriv ned i hvilken form og hvor mye potet du spiste her:
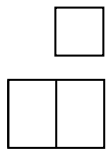

32. Spiste du grønnsaker til middag i går?

$\square$ Ja $\square$ Nei

Hvis ja, skriv ned hva slags og hvor mye grønnsaker du spiste her:

33. Drakk du juice til middag i går?

Ja $\square$ Nei

Hvis ja, skriv ned hva slags og hvor mye juice du drakk her:

34. Spiste du frukt eller bær til middag eller som dessert i går?

$\square \mathrm{Ja} \square$ Nei

Hvis ja, skriv ned hva slags og hvor mye frukt og bær du spiste her:

35. Drakk du vann til middag i går?

$\square$ Ja $\square$ Nei

NB: For spørsmål 35-40 skal du IKKE skrive hva og hvor mye du spiste/drakk

36. Drakk du brus MED sukker til middag i går?

$\square \mathrm{Ja} \square$ Nei

37. Drakk du brus UTEN sukker til middag i går?

$\square$ Ja $\square$ Nei

38. Spiste du nudler til middag i går?

Ja, vanlige middagsnudler $\quad \square$ Ja, Mr Lee eller lignende $\quad \square$ Nei

39. Spiste du boller, muffins, kake eller annen søt gjærbakst til middag eller som dessert i går?

$\square$ Ja $\square$ Nei

40. Spiste du snop, potetgull eller lignende til middag eller som dessert i går?

$\square$ Ja $\square$ Nei 
41. Spiste du kveldsmat i går kveld?

$\square$ Ja $\square$ Nei

42. Spiste du frukt eller bær etter middag eller til kvelds i går?

Kvelds

$\square$ Ja $\square$ Nei Hvis ja, skriv ned hva slags og hvor mye frukt og bær du spiste her:

43. Spiste du grønnsaker etter middag eller til kvelds i går?

$\square$ Ja $\square$ Nei

Hvis ja, skriv ned hva slags og hvor mye grønnsaker du spiste her:

(n)

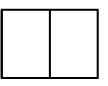

44. Drakk du juice etter middag eller til kvelds i går?

$\square$ Ja $\square$ Nei $\quad$ Hvis ja, skriv ned hva slags og hvor mye juice du drakk her:

.

45. Drakk du vann etter middag eller til kvelds i går?
$\mathrm{Ja}$
$\square$ Nei

NB: For spørsmål 45-50 skal du IKKE

skrive hva og hvor mye du spiste/drakk

46. Drakk du brus MED sukker etter middag eller til kvelds i går?

$\square$ Ja $\square$ Nei

47. Drakk du brus UTEN sukker etter middag eller til kvelds i går?

$\square$ Ja $\square$ Nei

48. Spiste du nudler (f.eks. Mr Lee) etter middag eller til kvelds i går?

$\square$ Ja $\square$ Nei

49. Spiste du boller, muffins, kake eller annen søt gjærbakst etter middag eller til kvelds i går?

$\square$ Ja $\square$ Nei

50. Spiste du snop, potetgull eller lignende etter middag eller til kvelds i går?

$\square$ Ja $\square$ Nei
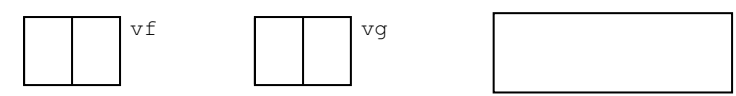


\section{Dine meninger om frukt og grønnsaker}

Nå kommer en rekke utsagn om frukt og grønnsaker. Hvor enig er du i de forskjellige utsagnene? Alternativene er helt uenig, litt uenig, litt enig eller helt enig. Hvis du ikke har noen mening, eller du ikke vet hva du skal svare, så krysser du av for verken enig eller uenig.

HUSK: Kun ett kryss for hvert spørsmål!

1. Jeg spiser alltid opp grønnsakene mine til middag

$\square$ Helt uenig
$\square$ Litt uenig
$\square$ Verken enig eller uenig
$\square$ Litt enig
$\square$ Helt enig

2. Det vil være lett for meg å spise mer enn 5 porsjoner frukt og grønnsaker hver dag

$\square$ Helt uenig
$\square$ Litt uenig
$\square$ Verken enig eller uenig
$\square$ Litt enig
$\square$ Helt enig

3. Hjemme har vi vanligvis frukt stående fremme i en skål

$\square$ Helt uenig
$\square$ Litt uenig
$\square$ Verken enig eller uenig
$\square$ Litt enig
$\square$ Helt enig

4. Det er lettere å spise søtsaker enn frukt og grønnsaker som snacks/mellommåltid

$\square$ Helt uenig
$\square$ Litt uenig
$\square$ Verken enig eller uenig
$\square$ Litt enig
$\square$ Helt enig

\section{Min far spiser mye frukt og} grønnsaker

$\square$ Helt uenig
$\square$ Litt uenig
$\square$ Verken enig eller uenig
$\square$ Litt enig
$\square$ Helt enig

6. Det hender ofte at jeg finner meg frukt og grønnsaker hjemme mellom måltider

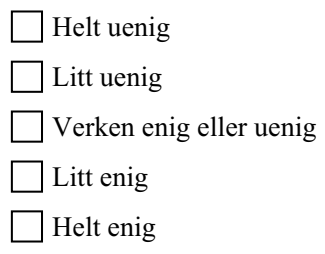

7. Min mor spiser mye frukt og grønnsaker

$\square$ Helt uenig
$\square$ Litt uenig
$\square$ Verken enig eller uenig
$\square$ Litt enig
$\square$ Helt enig

8. Det hender at jeg kutter opp frukt eller grønnsaker til meg selv som snacks

$$
\begin{aligned}
& \square \text { Helt uenig } \\
& \square \text { Litt uenig } \\
& \square \text { Verken enig eller uenig } \\
& \square \text { Litt enig } \\
& \square \text { Helt enig }
\end{aligned}
$$

9. Frukt og gronnsaker passer veldig godt som snacks/mellommåltid

$\square$ Helt uenig
$\square$ Litt uenig
$\square$ Verken enig eller uenig
$\square$ Litt enig
$\square$ Helt enig

10. Jeg ønsker å spise minst 5 porsjoner frukt og grønnsaker hver dag

$\square$ Helt uenig
$\square$ Litt uenig
$\square$ Verken enig eller uenig
$\square$ Litt enig
$\square$ Helt enig

11. Jeg spiser alltid frukt eller grønnsaker til skolematen

$\square$ Helt uenig
$\square$ Litt uenig
$\square$ Verken enig eller uenig
$\square$ Litt enig
$\square$ Helt enig

12. Hjemme har vi vanligvis alltid frukt og grønnsaker i kjøleskapet

$\square$ Helt uenig
$\square$ Litt uenig
$\square$ Verken enig eller uenig
$\square$ Litt enig
$\square$ Helt enig

13. Det ville være lett for meg å spise frukt eller gronnsaker til hvert måltid, hver dag, hvis jeg bestemte meg for å gjøre det

$\square$ Helt uenig
$\square$ Litt uenig
$\square$ Verken enig eller uenig
$\square$ Litt enig
$\square$ Helt enig

14. Hjemme har vi som regel grønnsaker til middag hver dag

$\square$ Helt uenig
$\square$ Litt uenig
$\square$ Verken enig eller uenig
$\square$ Litt enig
$\square$ Helt enig

15. Jeg spiser for lite frukt og grønnsaker

$\square$ Helt uenig
$\square$ Litt uenig
$\square$ Verken enig eller uenig
$\square$ Litt enig
$\square$ Helt enig


22. Jeg er glad i rå grønnsaker

$\square$ Helt uenig
$\square$ Litt uenig
$\square$ Verken enig eller uenig
$\square$ Litt enig
$\square$ Helt enig

23. Hjemme får jeg lov til å spise frukt og grønnsaker når jeg vil

$\square$ Helt uenig

17. Mer frukt og grønnsaker gjør at måltidene smaker bedre

$\square$ Helt uenig
$\square$ Litt uenig
$\square$ Verken enig eller uenig
$\square$ Litt enig
$\square$ Helt enig

18. Jeg spiser frukt og grønnsaker til hvert måltid

$\square$ Helt uenig
$\square$ Litt uenig
$\square$ Verken enig eller uenig
$\square$ Litt enig
$\square$ Helt enig

19. Frukt er noe av det beste jeg vet

$\square$ Helt uenig
$\square$ Litt uenig
$\square$ Verken enig eller uenig
$\square$ Litt enig
$\square$ Helt enig

20. Det hender at mor/far kutter opp frukt eller gronnsaker til meg som snacks

$\square$ Helt uenig
$\square$ Litt uenig
$\square$ Verken enig eller uenig
$\square$ Litt enig
$\square$ Helt enig

\section{Jeg spiser nok frukt og grønnsaker}

$\square$ Helt uenig
$\square$ Litt uenig
$\square$ Verken enig eller uenig
$\square$ Litt enig
$\square$ Helt enig

24. Jeg trenger å spise mer frukt og grønnsaker

$\square$ Helt uenig
$\square$ Litt uenig
$\square$ Verken enig eller uenig
$\square$ Litt enig
$\square$ Helt enig

25. Det vil være lett for meg å spise frukt eller grønnsaker, når alle andre spiser sjokolade og annet snop på lordagskvelder

$\square$ Helt uenig
$\square$ Litt uenig
$\square$ Verken enig eller uenig
$\square$ Litt enig
$\square$ Helt enig

26. Mange av mine venner, søsken og klassekammerater spiser mye frukt og grønnsaker

$\square$ Helt uenig
$\square$ Litt uenig
$\square$ Verken enig eller uenig
$\square$ Litt enig
$\square$ Helt enig
sorter frukt og grønnsaker som jeg kan spise

$\square$ Helt uenig
$\square$ Litt uenig
$\square$ Verken enig eller uenig
$\square$ Litt enig
$\square$ Helt enig

28. Hjemme er det vanligvis alltid frukt og grønnsaker som jeg liker $\square$ Helt uenig

$\square$ Litt uenig
$\square$ Verken enig eller uenig
$\square$ Litt enig
$\square$ Helt enig

29. Hvor godt liker du:

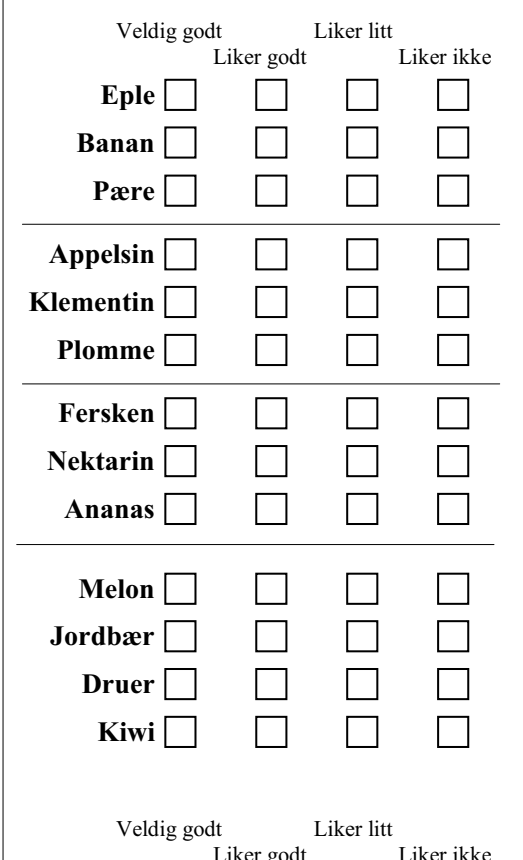

27. Hjemme er det vanligvis alltid flere

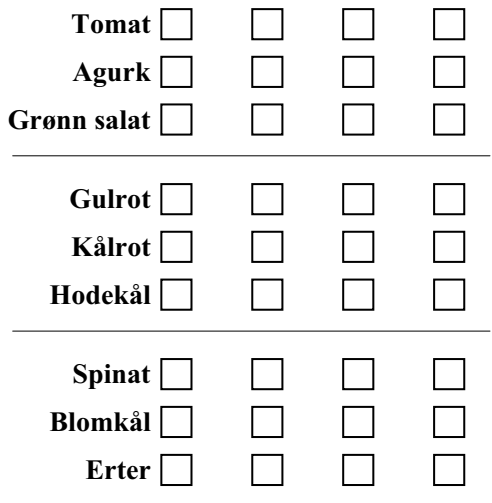

\begin{tabular}{|c|c|c|}
\hline Brokkoli $\square$ & $\square$ & $\mathrm{a}$ \\
\hline Mais $\square$ & 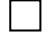 & ए \\
\hline Paprika $\square$ & $\square$ & 口 \\
\hline Løk $\square$ & $\square$ & $\square$ \\
\hline Potet $\square$ & $\square$ & - \\
\hline
\end{tabular}




\section{Hva spiser du vanligvis?}

\section{Del C}

Når du fyller ut disse spørsmålene skal du tenke på hva du vanligvis spiser/drikker. Tenk gjerne på hva du har spist/drukket de siste 3 månedene. Tenk på både hva du spiser hjemme, på skolen og i fritiden. Kryss av i den ruten du føler passer best for deg.

\section{Hvor ofte spiser du potet?}

$\square$ Aldri
$\square$ Sjeldnere enn 1 gang i uken
$\square$ 1 gang i uken
$\square$ 2 ganger i uken
$\square 3$ ganger i uken
$\square$ 4 ganger i uken
$\square 5$ ganger i uken
$\square 6$ ganger i uken
$\square$ Hver dag
$\square$ Flere ganger hver dag

2. Hvor ofte spiser du grønnsaker til middag?

$\square$ Aldri
$\square$ Sjeldnere enn 1 gang i uken
$\square$ 1 gang i uken
$\square 2$ ganger i uken
$\square 3$ ganger i uken
$\square 4$ ganger i uken
$\square 5$ ganger i uken
$\square 6$ ganger i uken
$\square$ Hver dag
$\square$ Flere ganger hver dag

\section{Hvor ofte spiser du grønnsaker} på brødskivene?

Aldri

$\square$ Sjeldnere enn 1 gang i uken

$\square 1$ gang i uken

$\square 2$ ganger i uken

$\square 3$ ganger i uken

$\square 4$ ganger i uken

$\square 5$ ganger i uken

$\square 6$ ganger i uken

$\square$ Hver eneste dag

$\square$ Flere ganger hver dag

\section{Hvor ofte spiser du andre grønnsaker? \\ (f.eks. gulrot til skolematen)}

\section{$\square$ Aldri}

$\square$ Sjeldnere enn 1 gang i uken

$\square 1$ gang i uken

$\square 2$ ganger i uken

$\square 3$ ganger i uken

$\square 4$ ganger i uken

$\square 5$ ganger i uken

$\square 6$ ganger i uken

$\square$ Hver dag

$\square$ Flere ganger hver dag

5. Hvor ofte spiser du eple, appelsin, pare og banan?

$\square$ Aldri

$\square$ Sjeldnere enn 1 gang i uken

$\square 1$ gang i uken

$\square 2$ ganger i uken

$\square 3$ ganger i uken

$\square 4$ ganger i uken

$\square 5$ ganger i uken

$\square 6$ ganger i uken

$\square$ Hver dag

$\square$ Flere ganger hver dag

\section{Hvor ofte spiser du annen frukt} og bær?

(andre frukter og bær enn eple, appelsin, pære og banan)

$\square$ Aldri
$\square$ Sjeldnere enn 1 gang i uken
$\square$ 1 gang i uken
$\square 2$ ganger i uken
$\square 3$ ganger i uken
$\square 4$ ganger i uken
$\square 5$ ganger i uken
$\square 6$ ganger i uken
$\square$ Hver dag
$\square$ Flere ganger hver dag

\section{Hvor ofte spiser du pommes frites?}

$\square$ Aldri

$\square$ Sjeldnere enn 1 gang i uken

$\square 1$ gang i uken

$\square 2$ ganger i uken

$\square 3$ ganger i uken

$\square 4$ ganger i uken

$\square 5$ ganger i uken

$\square 6$ ganger i uken

$\square$ Hver dag

Flere ganger hver dag

\section{Hvor ofte spiser du potetgull?}

$\square$ Aldri

$\square$ Sjeldnere enn 1 gang i uken

$\square 1$ gang i uken

$\square 2$ ganger i uken

$\square 3$ ganger i uken

$\square 4$ ganger i uken

$\square 5$ ganger i uken

$\square 6$ ganger i uken

$\square$ Hver dag

$\square$ Flere ganger hver dag

\section{Hvor ofte spiser du godterier?}

(sjokolade, blandet godt osv.)

$\square$ Aldri

$\square$ Sjeldnere enn 1 gang i uken

$\square 1$ gang i uken

$\square 2$ ganger i uken

$\square 3$ ganger i uken

$\square 4$ ganger i uken

$\square 5$ ganger i uken

$\square 6$ ganger i uken

$\square$ Hver dag

Flere ganger hver dag 
10. Hvor ofte spiser du nudler?

(f.eks. Mr Lee)

$\square$ Aldri

$\square$ Sjeldnere enn 1 gang i uken

$\square 1$ gang i uken

$\square 2$ ganger i uken

$\square 3$ ganger i uken

$\square 4$ ganger i uken

$\square 5$ ganger i uken

$\square 6$ ganger i uken

$\square$ Hver dag

$\square$ Flere ganger hver dag

11. Hvor ofte spiser du boller, muffins, kake eller annen sot gjærbakst?

$\square$ Aldri

$\square$ Sjeldnere enn 1 gang i uken

$\square 1$ gang i uken

$\square 2$ ganger i uken

$\square 3$ ganger i uken

$\square 4$ ganger i uken

$\square 5$ ganger i uken

$\square 6$ ganger i uken

Hver dag

Flere ganger hver dag

\section{Hvor ofte drikker du juice?}

$\square$ Aldri

$\square$ Sjeldnere enn 1 gang i uken

$\square 1$ gang i uken

$\square 2$ ganger i uken

$\square 3$ ganger i uken

$\square 4$ ganger i uken

$\square 5$ ganger i uken

$\square 6$ ganger i uken

$\square$ Hver dag

$\square$ Flere ganger hver dag
13. Hvor ofte drikker du saft?

$\square$ Aldri

$\square$ Sjeldnere enn 1 gang i uken

$\square 1$ gang i uken

$\square 2$ ganger i uken

$\square 3$ ganger i uken

$\square 4$ ganger i uken

$\square 5$ ganger i uken

$\square 6$ ganger i uken

$\square$ Hver dag

Flere ganger hver dag

14. Hvor ofte drikker du brus MED sukker?

$\square$ Aldri

$\square$ Sjeldnere enn 1 gang i uken

$\square 1$ gang i uken

$\square 2$ ganger i uken

$\square 3$ ganger i uken

$\square 4$ ganger i uken

$\square 5$ ganger i uken

$\square 6$ ganger i uken

$\square$ Hver dag

$\square$ Flere ganger hver dag

15. Hvor ofte drikker du brus UTEN sukker?

$\square$ Aldri

$\square$ Sjeldnere enn 1 gang i uken

$\square 1$ gang i uken

$\square 2$ ganger i uken

$\square 3$ ganger i uken

$\square 4$ ganger i uken

$\square 5$ ganger i uken

$\square 6$ ganger i uken

$\square$ Hver dag

$\square$ Flere ganger hver dag
16. Hvor ofte drikker du vann?

$\square$ Aldri

$\square$ Sjeldnere enn 1 gang i uken

$\square 1$ gang i uken

$\square 2$ ganger i uken

$\square 3$ ganger i uken

$\square 4$ ganger i uken

$\square 5$ ganger i uken

6 ganger i uken

$\square$ Hver dag

$\square$ Flere ganger hver dag

17. Hvor ofte har du med deg frukt eller grønnsaker hjemmefra på skolen?

$\square$ Hver skoledag

$\square 4$ dager i uken

$\square 3$ dager i uken

$\square 2$ dager i uken

$\square 1$ dag i uken

$\square$ Sjeldnere enn en dag i uken

$\square$ Aldri

$\square$ Vet ikke

\section{Hvor ofte spiser du frukt og} grønnsaker på skolen?

$\square$ Hver skoledag

$\square 4$ dager i uken

$\square 3$ dager i uken

$\square 2$ dager i uken

$\square 1$ dag i uken

$\square$ Sjeldnere enn en dag i uken

$\square$ Aldri

$\square$ Vet ikke 
19. Hvor ofte spiser du snop, potetgull eller lignende på skolen?

$\square$ Hver skoledag
$\square 4$ dager i uken
$\square 3$ dager i uken
$\square 2$ dager i uken
$\square 1$ dag i uken
$\square$ Sjeldnere enn en dag i uken
$\square$ Aldri
$\square$ Vet ikke

20. Hvor ofte spiser du nudler på skolen? (F.eks. Mr Lee)

$\square$ Hver skoledag
$\square 4$ dager i uken
$\square 3$ dager i uken
$\square 2$ dager i uken
$\square 1$ dag i uken
$\square$ Sjeldnere enn en dag i uken
$\square$ Aldri
$\square$ Vet ikke

\section{Del D}

\section{Noen spørsmål om deg og ditt}

1. Hvor mange porsjoner frukt og grønnsaker tror du at en på din alder bør spise hver dag?

$\square$ Ingen
$\square 1$
$\square 2$
$\square 3$
$\square 4$
$\square 5$
$\square$ Mer enn 5

21. Hvor ofte spiser du boller, muffins, kake eller annen søt gjærbakst på skolen?

$\square$ Hver skoledag
$\square$ 4 dager i uken
$\square 3$ dager i uken
$\square 2$ dager i uken
$\square 1$ dag i uken
$\square$ Sjeldnere enn en dag i uken
$\square$ Aldri
$\square$ Vet ikke

22. Hvor ofte drikker du brus MED sukker på skolen?

$\square$ Hver skoledag
$\square$ 4 dager i uken
$\square 3$ dager i uken
$\square 2$ dager i uken
$\square 1$ dag i uken
$\square$ Sjeldnere enn en dag i uken
$\square$ Aldri
$\square$ Vet ikke

23. Hvor ofte drikker du brus UTEN sukker på skolen?

$\square$ Hver skoledag
$\square$ 4 dager i uken
$\square$ 3 dager i uken
$\square 2$ dager i uken
$\square 1$ dag i uken
$\square$ Sjeldnere enn en dag i uken
$\square$ Aldri
$\square$ Vet ikke

\section{Hvor ofte drikker du vann på} skolen?
$\square$ Hver skoledag
4 dager i uken
$\square 3$ dager i uken
$\square 2$ dager i uken
$\square 1$ dag i uken
$\square$ Sjeldnere enn en dag i uken
$\square$ Aldri
Vet ikke

4. Er du allergisk mot frukt eller grønnsaker?

2. Hvor mange porsjoner frukt og grønnsaker tror du at du spiser hver dag?

$\square$ Ingen
$\square 1$
$\square 2$
$\square 3$
$\square 4$
$\square 5$
$\square$ Mer enn 5

3. Hva mener du om det å få utdelt en frukt eller en gronnsak på skolen hver dag?

$\square$ Det er veldig bra

$\square$ Det er bra

$\square$ Jeg har ikke noen mening om det

$\square$ Det er en dårlig ordning $\square$ Nei

$\square$ Usikker/vet ikke

$\square$ Ja, men bare mot noen få sorter $\square$ Ja, mot flere sorter

5. Hva veide du sist du veide deg? (Hele kg)

Skriv tydelig!

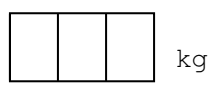

6. Hvor høy var du sist du målte deg? (Hele $\mathrm{cm}$ )

Uten komma!

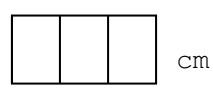




\section{Røyker du?}

$\square$ Har aldri røykt

$\square$ Har aldri røykt fast og røyker ikke i det hele tatt nå

$\square$ Har røykt fast, men har sluttet helt nå

$\square$ Røyker, men ikke daglig

$\square$ Røyker daglig, omtrent

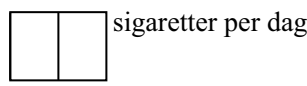

8. Har du noen gang drukket øl, vin eller brennevin?

(Kryss av for det svaret som passer best til ditt forbruk.)

$\square$ Jeg har aldri smakt øl, vin eller brennevin

$\square$ Jeg har så vidt smakt alkohol

$\square$ Drikker ca. 1 gang per måned

$\square$ Drikker ca. 1 gang per uke

$\square$ Drikker mer enn en gang per uke

\section{Prøver du å slanke deg?}

$\square$ Nei, vekten min er passe

$\square$ Nei, men jeg trenger å slanke meg

$\square$ Ja

10. Hvor lang utdanning tror du at du kommer til å ta? (Sett bare ett kryss!)

Utdanning på høyskole eller universitet

Yrkes- eller allmennfaglig utdanning på videregående skole

Ikke mer utdanning etter ungdomsskolen

Annet, skriv hva:
11. Hvor mange bøker tror du det er hjemme hos dere?

(50 bøker er ca. 1 meter i bokhyllen)

$\square$ Ingen bøker
$\square$ Mindre enn 20
$\square 20$ - 50
$\square 50$ - 100
$\square 100$ - 500
$\square 500$ - 1000
$\square$ Mer enn 1000

12. Utenom skoletid: Hvor mange timer per dag pleier du å se på TV og/eller sitte foran $\mathrm{PC}^{\prime} \mathrm{en}$ ?

$\square$ Ingen
$\square$ Mindre enn en $1 / 2$ time om dagen
$\square 1 / 2$ - 1 time
$\square 2$ - 3 timer
$\square 4$ timer
$\square$ Mer enn 4 timer

13. Utenom skoletid: Hvor mange GANGER i uken driver du idrett, eller mosjonerer du så mye at du blir andpusten og/eller svett?

Hver dag

4 - 6 ganger i uken

2 - 3 ganger i uken

En gang i uken

En gang i måneden

Mindre enn en gang i måneden

Aldri

\section{Noen spørsmål om brus}

\section{Del E}

\section{Hvor mye brus drakk du i løpet av forrige helg?}

Eks. Drakk du en halv liter - skriv 0,5

De dagene du ikke drakk brus - skriv $0 \mathrm{i}$ en av rubrikene

Skriv tydelig!

\section{Brus MED sukker}
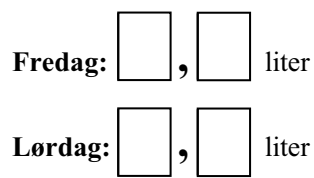

Søndag: $\square$ liter
2. Brus UTEN sukker
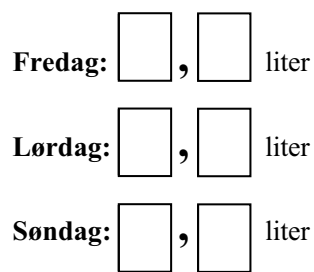

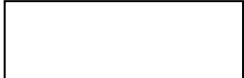


3. Hvor mye brus drikker du vanligvis hver gang du drikker brus?

$\square$ Mindre enn 0,5 liter

$\square$ Omtrent 0,5 liter

$\square$ Mer enn 0,5 liter

\section{Hvor ofte finnes det brus MED} sukker i hjemme hos deg?

$\square$ Aldri
$\square$ Sjeldnere enn 1 dag i måneden
$\square$ Sjeldnere enn 1 dag i uken
$\square 1$ dag i uken
$\square 2$ dager i uken
$\square 3$ dager i uken
$\square 4$ dager i uken
$\square 5$ dager i uken
$\square 6$ dager i uken
$\square$ Alltid/hver dag

5. Hvor ofte finnes det brus UTEN sukker hjemme hos deg?

$\square$ Aldri
$\square$ Sjeldnere enn 1 dag i måneden
$\square$ Sjeldnere enn 1 dag i uken
$\square 1$ dag i uken
$\square 2$ dager i uken
$\square 3$ dager i uken
$\square 4$ dager i uken
$\square 5$ dager i uken
$\square 6$ dager i uken
$\square$ Alltid/hver dag

6. Når det finnes brus hjemme hos deg, kan du drikke når du vil?

$\square$ Nei, sjelden
$\square$ Av og til
$\square$ Ja, som regel
$\square$ Ja, alltid

7. Hvor ofte serveres brus MED sukker til middag hjemme hos deg?

\section{Aldri}

Sjeldnere enn 1 gang i måneden

Sjeldnere enn 1 gang i uken

1 gang i uken

$\square 2$ ganger i uken

$\checkmark 3$ ganger i uken

$\square 4$ ganger i uken

$\square 5$ ganger i uken

$\square 6$ ganger i uken

$\square$ Hver dag

\section{Hvor ofte serveres brus UTEN} sukker til middag hjemme hos deg?

$\square$ Aldri

$\square$ Sjeldnere enn 1 gang i måneden

$\square$ Sjeldnere enn 1 gang i uken

$\square 1$ gang i uken

$\square 2$ ganger i uken

$\square 3$ ganger i uken

$\square 4$ ganger i uken

$\square 5$ ganger i uken

$\square 6$ ganger i uken

$\square$ Hver dag

9. Hvor ofte serverer din mor eller far deg brus MED sukker hjemme utenom middag?

$\square$ Aldri

$\square$ Sjeldnere enn 1 gang i måneden

$\square$ Sjeldnere enn 1 gang i uken

$\square$ 1 gang i uken

$\square 2$ ganger i uken

$\square 3$ ganger i uken

$\square 4$ ganger i uken

$\square 5$ ganger i uken

$\square 6$ ganger i uken

$\square$ Hver dag
10. Hvor ofte serverer din mor eller far deg brus UTEN sukker hjemme utenom middag?

$\square$ Aldri

Sjeldnere enn 1 gang i måneden

$\square$ Sjeldnere enn 1 gang i uken

$\square 1$ gang i uken

$\square 2$ ganger i uken

$\square 3$ ganger i uken

4 ganger i uken

$\square 5$ ganger i uken

$\square 6$ ganger i uken

$\square$ Hver dag

11. Hvor langt er det fra hjemmet ditt til nærmeste sted du kan kjøpe brus?

$\square$ Mindre enn 50 meter
$\square 50$ - 100 meter
$\square 100$ - 250 meter
$\square 250$ - 500 meter
$\square 0,5-1 \mathrm{~km}$
$\square 1-2 \mathrm{~km}$
$\square 2-3 \mathrm{~km}$
$\square 3-5 \mathrm{~km}$
$\square 5-10 \mathrm{~km}$
$\square$ Mer enn $10 \mathrm{~km}$

12. Hvor langt er det fra skolen din til nærmeste sted du kan kjøpe brus.?

$\square$ Mindre enn 50 meter
$\square 50-100$ meter
$\square 100-250$ meter
$\square 250-500$ meter
$\square 0,5-1 \mathrm{~km}$
$\square 1-2 \mathrm{~km}$
$\square 2-3 \mathrm{~km}$
$\square 3-5 \mathrm{~km}$
$\square 5-10 \mathrm{~km}$
$\square$ Mer enn $10 \mathrm{~km}$


13. Hvor ofte drikker din mor brus MED sukker?

$\square$ Aldri

$\square$ Sjeldnere enn 1 gang i uken

$\square 1$ gang i uken

$\square 2$ ganger i uken

$\square 3$ ganger i uken

$\square 4$ ganger i uken

5 ganger i uken

$\square 6$ ganger i uken

$\square$ Hver dag

$\square$ Flere ganger hver dag

Har ikke mor (hopp til sp. 15)

\section{Hvor ofte drikker din mor brus} UTEN sukker?

$\square$ Aldri

$\square$ Sjeldnere enn 1 gang i uken

$\square 1$ gang i uken

$\square 2$ ganger i uken

$\square 3$ ganger i uken

$\square 4$ ganger i uken

5 ganger i uken

$\square 6$ ganger i uken

$\square$ Hver dag

$\square$ Flere ganger hver dag

15. Hvor ofte drikker din far brus MED sukker?

$\square$ Aldri

$\square$ Sjeldnere enn 1 gang i uken

$\square 1$ gang i uken

$\square 2$ ganger i uken

$\square 3$ ganger i uken

$\square 4$ ganger i uken

$\square$ ganger i uken

$\square 6$ ganger i uken

$\square$ Hver dag

Flere ganger hver dag

Har ikke far (hopp til sp. 17)
16. Hvor ofte drikker din far brus UTEN sukker?

$\square$ Aldri

$\square$ Sjeldnere enn 1 gang i uken

$\square 1$ gang i uken

$\square 2$ ganger i uken

$\square 3$ ganger i uken

$\square 4$ ganger i uken

$\square 5$ ganger i uken

$\square 6$ ganger i uken

$\square$ Hver dag

$\square$ Flere ganger hver dag

\section{Hvor ofte drikker dine søsken} brus MED sukker?

Tenk gjennomsnitt. Sett bare ett kryss.

$\square$ Aldri

$\square$ Sjeldnere enn 1 gang i uken

$\square 1$ gang i uken

$\square 2$ ganger i uken

$\square 3$ ganger i uken

$\square 4$ ganger i uken

$\square 5$ ganger i uken

$\square 6$ ganger i uken

$\square$ Hver dag

$\square$ Flere ganger hver dag

$\square$ Har ikke søsken (hopp til sp. 19)

\section{Hvor ofte drikker dine søsken} brus UTEN sukker?

Tenk gjennomsnitt. Sett bare ett kryss.

$\square$ Aldri

$\square$ Sjeldnere enn 1 gang i uken

$\square 1$ gang i uken

$\square 2$ ganger i uken

$\square 3$ ganger i uken

$\square 4$ ganger i uken

$\square 5$ ganger i uken

$\square 6$ ganger i uken

$\square$ Hver dag

Flere ganger hver dag
19. Hvor ofte drikker dine beste venner brus MED sukker?

Tenk gjennomsnitt. Sett bare ett kryss.

$\square$ Aldri

$\square$ Sjeldnere enn 1 gang i uken

$\square 1$ gang i uken

$\square 2$ ganger i uken

$\square 3$ ganger i uken

$\square 4$ ganger i uken

$\square 5$ ganger i uken

$\square 6$ ganger i uken

$\square$ Hver dag

Flere ganger hver dag

$\square$ Har ikke venner (hopp til sp. 21)

20. Hvor ofte drikker dine beste venner brus UTEN sukker?

Tenk gjennomsnitt. Sett bare ett kryss.

$\square$ Aldri

$\square$ Sjeldnere enn 1 gang i uken

$\square 1$ gang i uken

$\square 2$ ganger i uken

$\square 3$ ganger i uken

$\square 4$ ganger i uken

$\square 5$ ganger i uken

$\square 6$ ganger i uken

Hver dag

Flere ganger hver dag

21. Brus MED sukker egner seg godt til mat

$\square$ Helt uenig

$\square$ Litt uenig

$\square$ Verken enig eller uenig

$\square$ Litt enig

$\square$ Helt enig

22. Brus UTEN sukker egner seg godt til mat

$\square$ Helt uenig

$\square$ Litt uenig

Verken enig eller uenig

Litt enig

Helt enig 3440

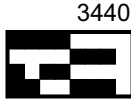


23. Brus MED sukker egner seg godt som torstedrikk

$\square$ Helt uenig

$\square$ Litt uenig

$\square$ Verken enig eller uenig

$\square$ Litt enig

Helt enig

24. Brus UTEN sukker egner seg godt som tørstedrikk

$\square$ Helt uenig

$\square$ Litt uenig

Verken enig eller uenig

$\square$ Litt enig

$\square$ Helt enig
25. Brus MED sukker er godt for helsen

$\square$ Helt uenig

$\square$ Litt uenig

$\square$ Verken enig eller uenig

Litt enig

Helt enig

26. Brus UTEN sukker er godt for helsen

$\square$ Helt uenig

$\square$ Litt uenig

$\square$ Verken enig eller uenig

$\square$ Litt enig

$\square$ Helt enig
27. På en skala fra 0 til 10, hvor godt liker du brus MED sukker?

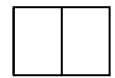

Skriv tydelig!

28. På en skala fra 0 til 10, hvor godt liker du brus UTEN sukker?

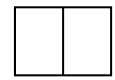

\section{TAKK FOR HJELPEN!}

Har du noe du vil si om ernæring/kosthold/mat?

Skriv det her! 
APPENDIX II

English translation of the questionnaire items 



\begin{tabular}{|c|c|c|c|c|c|c|c|c|c|c|c|c|c|c|c|c|c|c|c|c|c|}
\hline 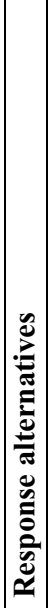 & 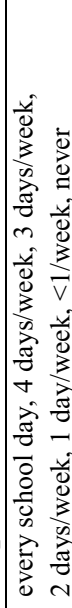 & 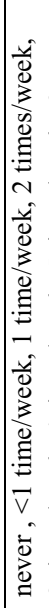 & 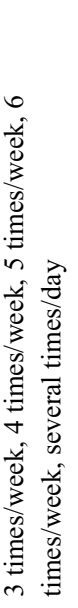 & & & 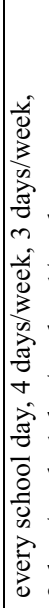 & 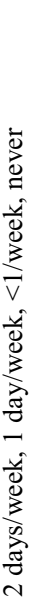 & & & & & 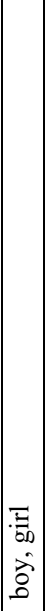 & 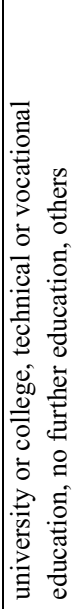 & & & 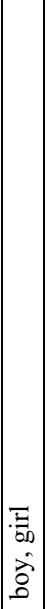 & 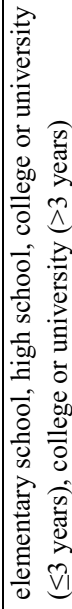 & & \multicolumn{3}{|l|}{ 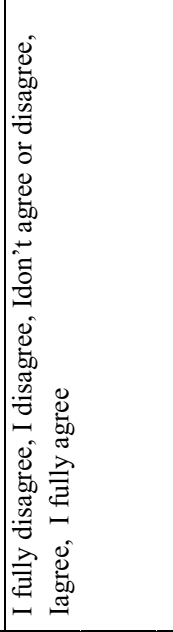 } \\
\hline 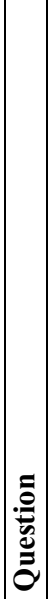 & 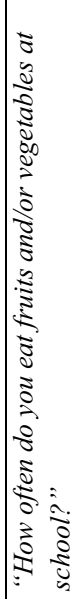 & 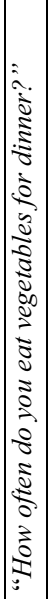 & 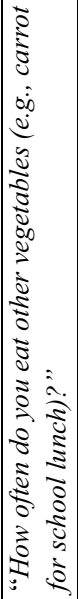 & 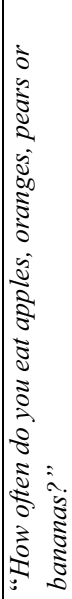 & 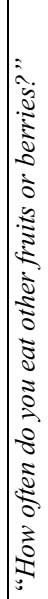 & 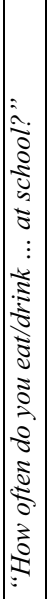 & 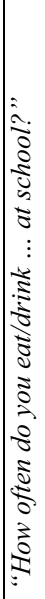 & 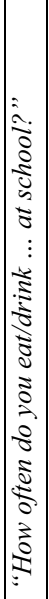 & 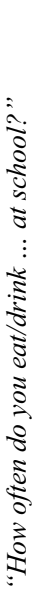 & 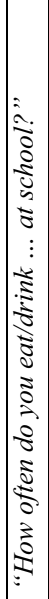 & 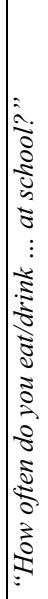 & 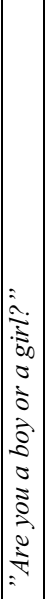 & 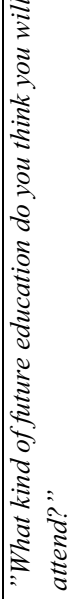 & & 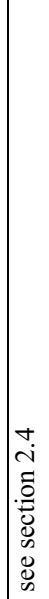 & 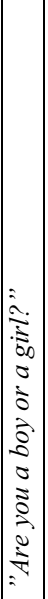 & 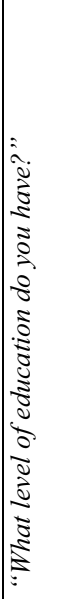 & & 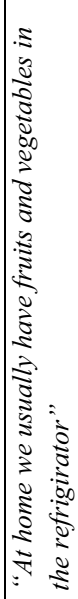 & 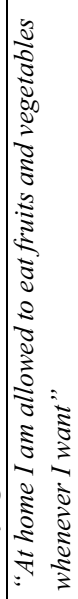 & \\
\hline 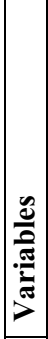 & 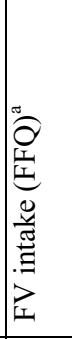 & & & & & 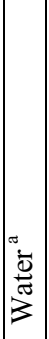 & 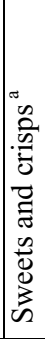 & 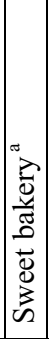 & 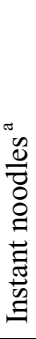 & 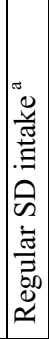 & 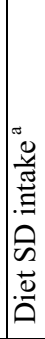 & 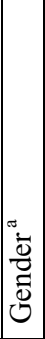 & 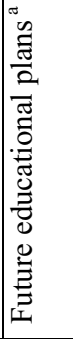 & 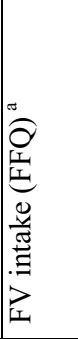 & 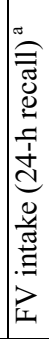 & 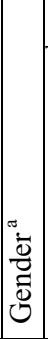 & 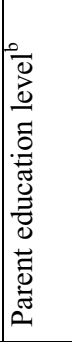 & 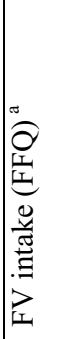 & 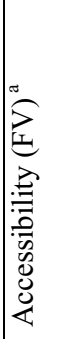 & & \\
\hline 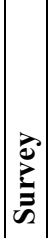 & 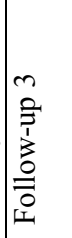 & & & & & & & & & & & & & 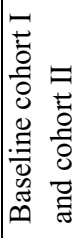 & & & & 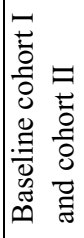 & & & \\
\hline 岕 & - & & & & & & & & & & & & & I & & & & 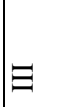 & & & \\
\hline
\end{tabular}




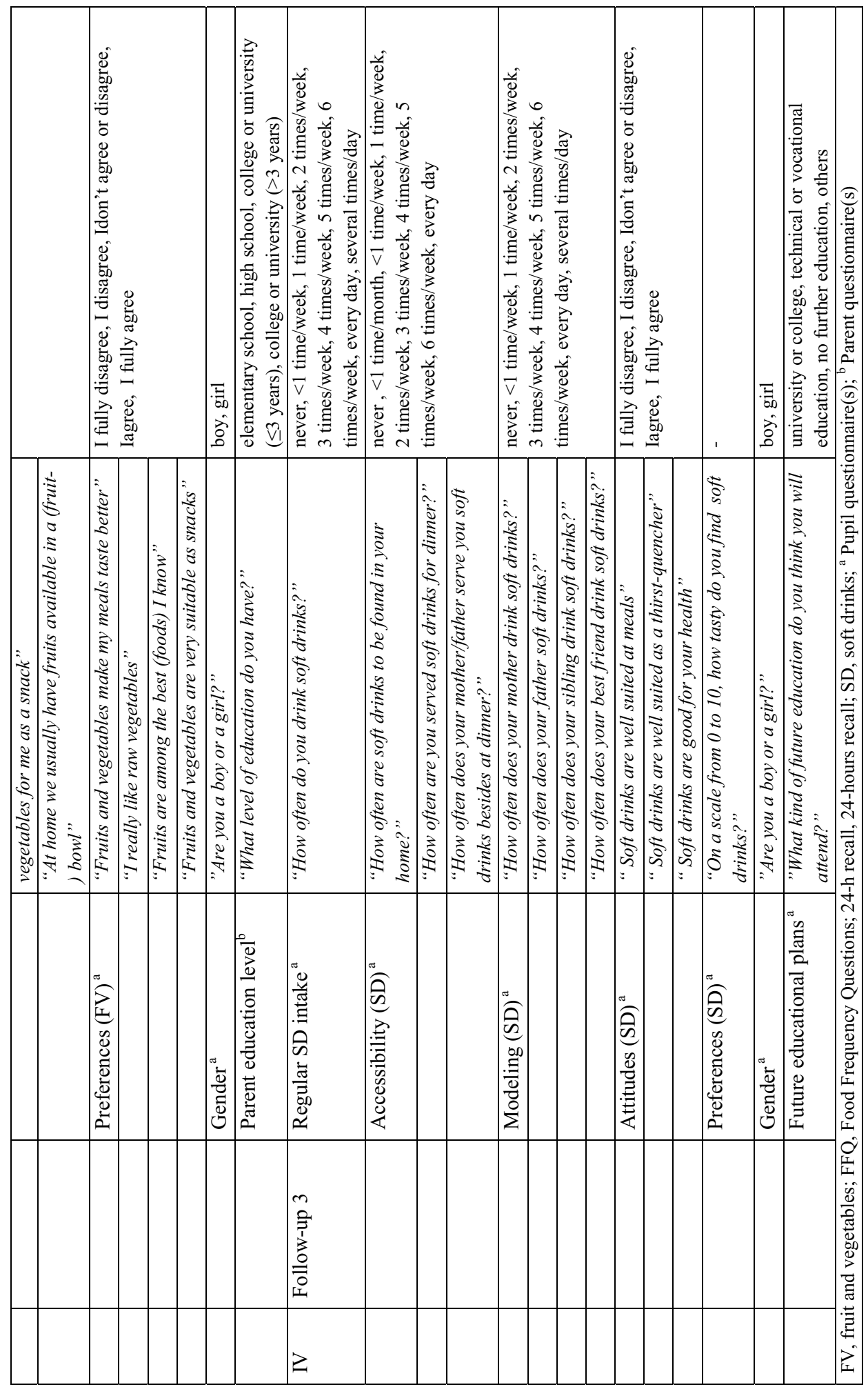

